\title{
IMPLANTAÇÃo E AVALIAÇÃo DA INICIATIVA HOSPITAL AMIGO dA CRIANÇA NA UNIDADE DE NEONATOLOGIA DO HOSPITAL UNIVERSITÁRIO REGIONAL DO NORTE dO PARANÁ, LONDRINA
}

Marli Terezinha Oliveira Vannuchi

Tese apresentada aO Departamento de Nutrição da faculdade de Saúde Pública da Universidade de São paulo para obtenção DO GRAU DE DOUTOR.

ORIENTADOR

Prof. Dr. Carlos augusto Monteiro

CO-ORIENTADORA:

Profa Dra marina ferreira Réa

Área de Concentração:

NUTRIÇÃo 
Autorizo, exclusivamente para fins acadêmicos e científicos, a reprodução total ou parcial desta tese, por processos fotocopiadores. Assinatura:

Data: 1

$$
1226412002 \text { doc }
$$




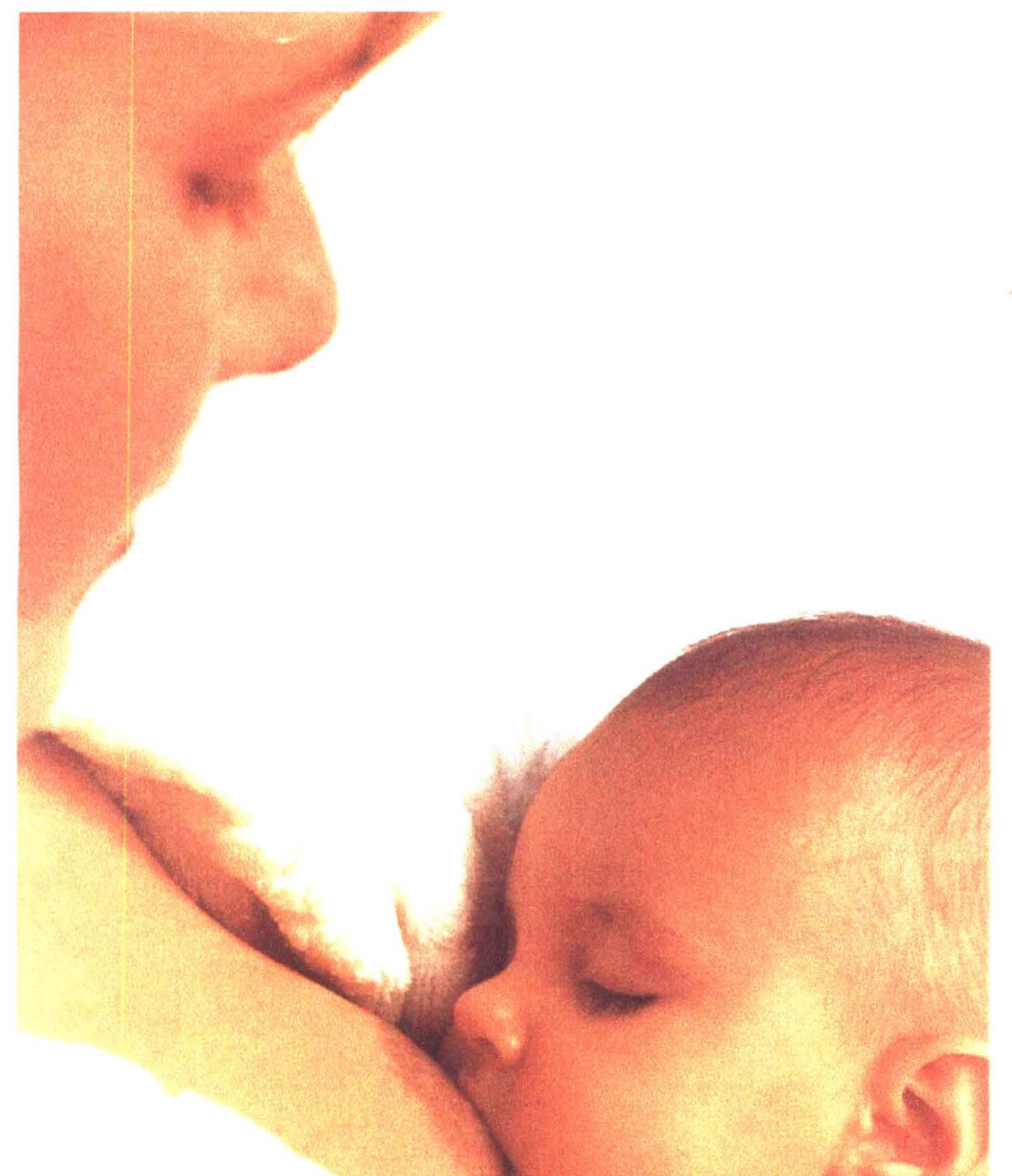

Aqui está o meu corpo, aqui está o meu sangue, Leite Materno.

Vida de todas as crianças.

Suga... Bebe...

Mata a tua fome...

Vive!!!!

Rubem Alves 


\section{Dedicatória}

\section{$\mathscr{A}$ Deus}

Agradeço a sua presença constante em meu coração mostrando-me caminbos e dando-me forças para prosseguir. 


\title{
Agradecimentos
}

Â Edison. meu esposo, companbeiro e amigo de todos os momentos.

Sua compreensão, ajuda e incentivo foram essenciais para que eu pudesse concluir este trabalbo.

A oocêo meu amor;

\begin{abstract}
A meus filbos, Thiago e Rafaela. tenbam certeza absoluta que vocês estāo acima de qualquer trabalbo que a mamãe venba a desenoolver. Adoro vocês e obrigada por terem dado a mim a oportunidade de amamentá-los;

A minba familia. em especial a minba imã Célia. pelo incentioo e apoio em momentos delicados desta trajetória:
\end{abstract}

$\mathscr{A}$ minha amiga e auxiliar Marta. pelo carinbo, amor e trabalbo dispensados à minba familia enquanto estioe ausente;

Aos meus orientadores, Prof. Dr. Carlos Augusto Monteiro e Profa. Dra. Marina Ferreira Réa. pelas orientaçōes seguras ao longo desse trabalbo; 
Ao Departamento de Enfermagem da UEL, pelo apoio irrestrito que me foi concedido, em especial, aos professores do setor Mlédica-Cinirgica por terem assumido minhas tarefas durante o periodo em que estive ausente;

Ȧ Universidade Estadual de Londrina, em especial à Coordenadoria de Pás-Graduaçāo, pelo incentioo, apoio e liberação temporária das minbas atividades acadêmicas:

भ̇s amigas do peito Márcia, Andreza, Zuleika, Dalete. Kátia e Inete pelas inúmeras sugestōes e pela amizade, que se fortaleceu durante as viagens que fizemos por este

Brasil em busca de conbecimentos sobre Aleitamento Matemo;

\title{
$\grave{\mathscr{A}}$ Dra Sara,
}

Pelas valiosas sugestães;

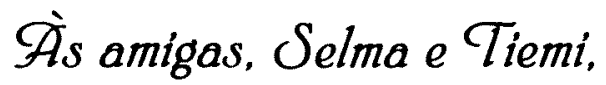
pela ajuda irrestrita, disponibilidade e valiosas orientações nos cáculos estatisticos;
\end{abstract}

A Elma, Marta, Dulce e Cláudia, pela a amizade e pelos bons momentos que passamos juntas ao longo deste curso: 
A Soninba e Ana Rosa, pela paciência que tiveram para lidar com as inconstâncias do texto e também pela dedicaçâo e amizade:

A Maria Melena e Alexandrina pelas sugestôes e ensinamentos durante as discussões sobre a metodologia qualitatioa;

$\grave{A}$ amiga e pedagoga Maria Jilce, pelo apoio e incentioo desde a época em que foi minba professora durante a graduação. Samais me esquecerei dos seus ensinamentos e da sua amizade;

\section{$\mathscr{A}$ Édna.} pela amizade construida ao longo deste trabalbo, pelo seu bom bumor, por sua dedicação a este trabalbo e incentioo em momentos dificeis;

$\grave{\mathscr{A}}$ s funcionárias e amigas do Banco de Leite do HURNP, pelo apoio irrestrito a este trabalbo e pela amizade;

Aos funcionários do SAME/HURNP $e$ SAME/AHC,

pela disponibilidade e pronto atendimento durante a coleta dos dados:

A todos os profissionais de saúde que foram entreoistados, pela postura ética e contribuiçāo a esta pesquisa; 


\section{ஷ্s bibliotecárias do HURNP,}

em especial a Dirce e Lucy pela disponibilidade e orientação:

\section{भ̇s bibliotecárias da FSPIUSP,} em especial à Vanda pela atenção, carinbo e pronto atendimento;

$\grave{A}$ CAPES (Coordenação de Apperfeiçoamento de Pessoal de Pioel Superior) pela bolsa de estudo concedida;

ஷ্s acadêmicas de Enfermagem. que auxiliaram na coleta dos dados;

$\mathcal{A}$ todos aqueles que acrescentaram conteúdo a esta elaboração de conbecimento e que não foram citados nominalmente.

$\grave{A} q u e l e s$ amigos que torceram para a finalização deste trabalbo o meu Muito Obrigada, de coração. 


\section{ÍNDICE}

1 INTRODUÇÃO 1

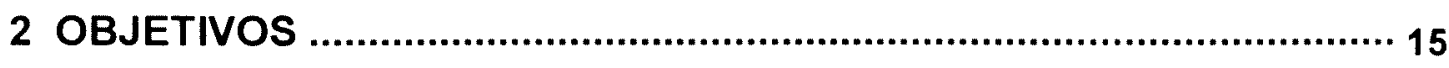

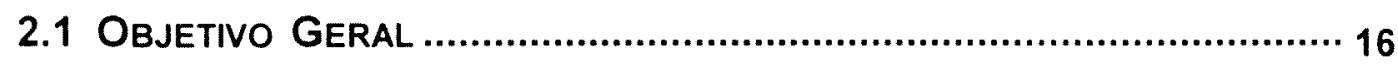

2.2 OBJETIVOS ESPECIFICOS ............................................................. 16

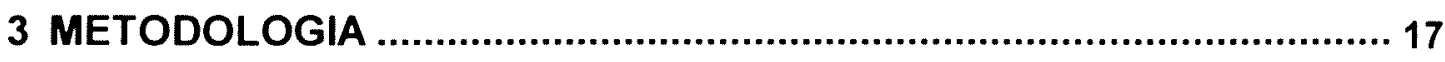

3.1 LOCAL DE ESTUDO ............................................................................. 18

3.1.1 CARACTERISTICAS DO MUNICIPIO DE LONDRINA E DA UNIVERSIDADE ESTADUAL DE LONDRINA …...................... 18

3.1.2 O Aleitamento Materno no Municipio de Londrina ........... 19

3.1.3 CARACTERISTICAS DO HOSPITAL UNIVERSITÁRIO REGIONAL DO NORTE do PARANA (HURNP) E SUA UNIDADE DE NEONATOLOGIA …...................................... 24

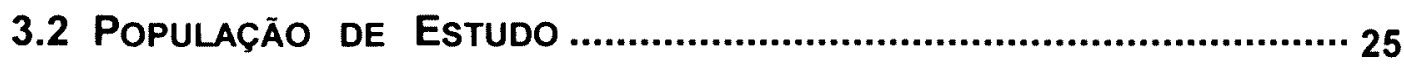

3.3 Aprovação pelo Comitê de Ética em Pesquisa ............................ 26

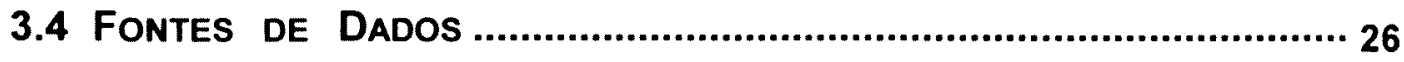

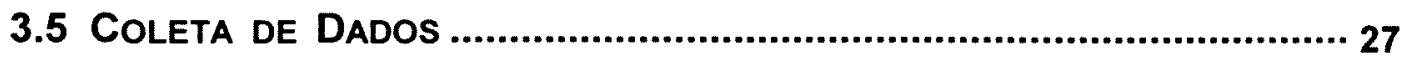

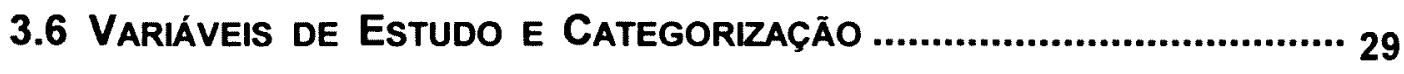

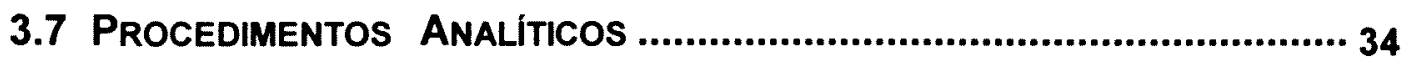

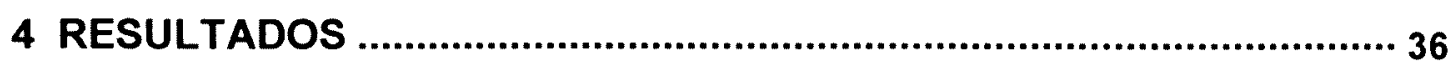

4.1 ETAPAS dA IMPLANTAÇÃo DA IHAC NO HURNP …........................ 37

4.2 Rotinas Sobre a Prática do Aleitamento Materno no HURNP, ANTES E APós a IMPLANTAÇão da IHAC 
4.3 Evolução do Padrão Alimentar dos Pacientes INTERNADOS NA UTI/UCI NEONATAL DO HURNP

4.3.1 Estudo Preliminar da EVolução do Padrão ALIMENTAR DOS PACIENTES INTERNADOS DURANTE os Meses de Março e Abril, no Periodo de 1994 A 1998

4.3.2 Evolução do Padrão Alimentar dos Pacientes INTERNADOS NA UTI/UCI NEONATAL DO HURNP DURANTE OS ANOS DE 1994 E 1998

4.4 Freqüência do Aleitamento Materno nos Primeiros Seis Primeiros Meses de Vida em Pacientes Internados na UTI/UCI Neonatal do HURNP, EM 1994 E 1998

5 DISCUSSÃO 73

5.1 Considerações Metodológicas

5.2 Impacto da iHAC no Aleitamento Materno NA UTI/UCI NEONATAL DO HURNP

5.2.1 A Freqüencia do Aleitamento Materno Nos PRIMEIROS SEIS MESES DE VIDA

6 CONCLUSÕES

7 REFERÊNCIAS

\section{ANEXOS}

Anexo 1 - Termo de AprovaçÃo no Comité de ÉtICA da FSP/USP 143

Anexo 2 - Termo de Aprovaçåo no Comité de Ética em Pesquisa DA UEL

ANEXO 3 - AUTORIZAÇÃo dA DIREÇÃo ClínICA DOHURNP 145

ANeXo 4 - AutorizAÇÃo das Chefias MÉdica e EnFERMAgem DA UnIDADE DE NEONATOLOGIA DO HURNP

ANexo 5 - Roteiro para Coleta de Dados dos Prontuários

ANEXO 6 - ROTEIRO DE ENTREVISTA 149

ANEXO 7 - TERMO DE CONSENTIMENTO LIVRE E ESCLARECIDO 158 


\section{LISTA DE TABELAS}

TABELA 1 Distribuição percentual de recém-nascidos segundo o tipo de alimentação recebida durante internação na UTI/UCI neonatal do HURNP em Londrina, PR, 1994 a 1998.

TABELA 2 Características dos recém-nascidos internados na UTI/UCI neonatal do HURNP em Londrina, PR, 1994 e 1998

TABELA 3 Distribuição percentual de recém-nascidos, segundo o tipo de alimentação recebida durante internação na UTI/UCI neonatal do HURNP em Londrina, PR, 1994 e 1998.

TABela 4 Distribuição de recém-nascidos, segundo regime alimentar e Odds Ratio para AME durante internação na UTI/UCI neonatal HURNP em Londrina, PR, 1994 e 1998

TABELA 5 Características dos recém-nascidos internados na UTI/UCI neonatal do HURNP com ausência de informação sobre o regime alimentar após alta hospitalar. Londrina, PR, 1994 e 1998

TABela 6 Características dos recém-nascidos internados na UTI/UCI neonatal do HURNP, acompanhados ao longo dos primeiros seis meses de vida. Londrina, PR, 1994 e 1998

TABela 7 Análise do tempo de AME através da regressão de Cox univariada e multivariada: Qui-quadrado de Wald, valor de $p$, Odds Ratio e Intervalo de Confiança de $95 \%$ em recém-nascidos internados na UTI/UCI neonatal do HURNP, acompanhados nos primeiros seis meses de vida. Londrina, PR, 1994 e 1998. 


\section{LISTA DE SIGLAS}

\begin{tabular}{|c|c|}
\hline AA & Aleitamento Artificial \\
\hline AHC & Ambulatório do Hospital de Clínicas \\
\hline AIG & Adequado para a Idade Gestacional \\
\hline AM & Aleitamento Materno \\
\hline AME & Aleitamento Materno Exclusivo \\
\hline AT & A Termo \\
\hline BLH & Banco de Leite Humano \\
\hline CALMA & Comitê de Estímulo ao Aleitamento Materno \\
\hline CCS & Centro de Ciências da Saúde \\
\hline COUNP & Centro Odontológico Universitário do Norte do Paraná \\
\hline DHA & Ácido docohexaenóico \\
\hline $\mathbf{E}$ & Entrevistado \\
\hline GEAM & Grupo de Estímulo ao Aleitamento Materno \\
\hline GIG & Grande para a Idade Gestacional \\
\hline HURNP & Hospital Universitário Regional do Norte do Paraná \\
\hline IBFAN & Rede Internacional em Defesa do Direito de Amamentar \\
\hline IBGE & Instituto Brasileiro de Geografia e Estatística \\
\hline IC & Intervalo de Confiança \\
\hline $\lg A$ & Imunoglobulina A \\
\hline IHAC & Iniciativa Hospital Amigo da Criança \\
\hline MS & Ministério da Saúde \\
\hline
\end{tabular}




\begin{tabular}{ll} 
NBCAL & Norma Brasileira para Comercialização de Alimentos para \\
NS & Lactentes \\
OD & Não Significativo \\
OMS & Odds Ratio \\
PEAM & Organização Mundial da Saúde \\
PIG & Programa de Estímulo ao Aleitamento Materno \\
PR & Pequeno para a Idade Gestacional \\
PROUNI-LD & Projeto UNI Londrina - Uma nova iniciativa na educação dos \\
PT & profissionais de Saúde: União com a comunidade \\
SESA & Prematuro \\
UBS & Secretaria de Estado de Saúde \\
UCI & Unidade Básica de Saúde \\
UEL & Unidade de Cuidados Intensivos \\
UNICEF & Universidade Estadual de Londrina \\
UTI & Fundo das Nações Unidas para a Infância \\
WHO & Wnidade de Terapia Intensiva \\
\hline
\end{tabular}




\section{RESUMO}

Vannuchi MTO. Implantação e avaliação da Iniciativa Hospital Amigo da Criança na Unidade de Neonatologia do Hospital Universitário do Norte do Paraná, Londrina. São Paulo; 2002. [Tese de Doutorado - Faculdade de Saúde Pública. Universidade de São Paulo].

Objetivo. Este estudo teve por objetivo avaliar o papel da Iniciativa Hospital Amigo da Criança na prática do aleitamento materno durante a internação de recém-nascidos na Unidade de Neonatologia do HURNP e após a alta, ao longo dos primeiros seis meses de vida. Métodos. A amostra do estudo constituiu-se de todos os recém-nascidos internados na unidade de neonatologia do HURNP durante os anos de 1994( $n=285)$ e $1998 \quad(n=368)$. A metodologia constou da análise de prontuários dos recém-nascidos; consulta e análise de todos os documentos e registros referentes ao processo de implantação da IHAC no HURNP e entrevistas com profissionais de saúde do setor de neonatologia. Resultados. Ocorreram mudanças significativas no regime alimentar do grupo de recém-nascidos internados na unidade de neonatologia do HURNP entre 1994 e 1998. Houve aumento expressivo do percentual de crianças que passaram a receber exclusivamente leite humano (de 1,9\% em 1994 para 41,7\% em 1998) e a alimentação exclusiva por fórmulas deixou de existir (de 17,9\% em 1994 para $0,0 \%$ em 1998). No que se refere ao aleitamento materno nos primeiros seis meses de vida, o tempo mediano do aleitamento materno exclusivo aumentou de 12 dias em 1994 para 45 dias em 1998 e, quanto ao aleitamento materno năo houve diferença significativa. Conclusão. A implantação da IHAC na Unidade de Neonatologia do HURNP contribuiu para aumentar tanto os índices do aleitamento materno como do aleitamento materno exclusivo, durante a internação dos recém-nascidos na Unidade de Neonatologia do HURNP e, nos primeiros seis meses de vida, contribuiu para o aumento dos índices do aleitamento materno exclusivo.

DESCRITORES: Aleitamento materno. Desmame precoce. Iniciativa Hospital Amigo da Criança. Prematuros. Baixo peso ao nascer. 


\section{SUMMARY}

Vannuchi MTO. Implantation and evaluation of the Baby-Friendly Hospital Initiative in the Neonatal Sector of the University Hospital of North of Parana, Londrina. São Paulo; 2002. [Doctor's degree thesis - Faculdade de Saúde Pública. Universidade de São Paulo].

Purpose: The purpose of this work was to evaluate the role of the Baby-Friendly Hospital Initiative in the breastfeeding practices throughout the first six months of life of the newborn babies in the Neonatal Sector of the University Hospital of North of Parana, including the hospitalization period. Methods: The sample included all the newborn babies hospitalized in the Neonatal Sector during 1994 $(n=285)$ and $1998 \quad(n=368)$. The methodology included analysis of the medical dossier of the newborn babies; study and analyses of all the documents concerning the implantation of the Baby-Friendly Hospital Initiative in the University Hospital, and interviews with the health professional team of the Neonatal Sector. Results: Significant changes occurred in the diet of the newborn babies hospitalized in the neonatal sector of the University Hospital between 1994 and 1998. There was a relevant increase of the percentage of infants fed only with human milk (from $1,9 \%$ in 1994 to $41,7 \%$ in 1998), and artificial milk was not used anymore $(17,9 \%$ in 1994 to $0,0 \%$ in 1998). With respect to the breastfeeding practices during the first six months, the median time of exclusive breastfeeding increased from 12 days in 1994 to 45 days in 1998; concerning breastfeeding, there was no significant difference. Conclusions: The implantation of the Baby-Friendly Hospital Initiative in the Neonatal Sector of the University Hospital contributed to the increasing of both the exclusive breastfeeding and the breastfeeding levels during the hospitalization period of the newborn babies in this sector and, during the first six months of life, there was an increase of the exclusive breastfeeding levels.

DESCRIPTORS: Breastfeeding. Early wean. Baby-Friendly Hospital Initiative. Premature babies. Low birth weight. 


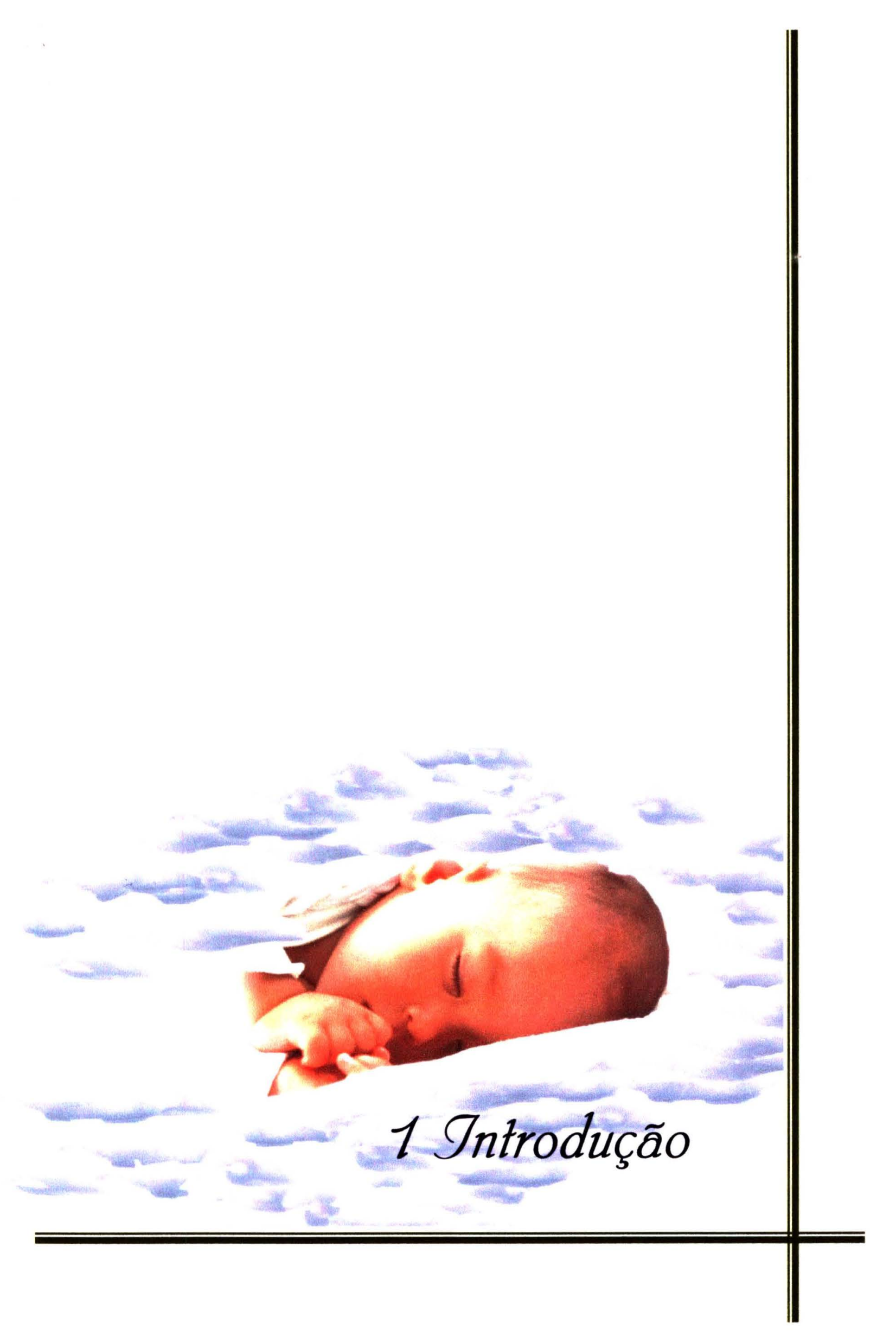


A amamentação é o método de escolha para todos os bebês normais por suas inúmeras vantagens tanto para a saúde da criança quanto da mãe (AKRÉ 1994).

O leite materno apresenta, em sua composição, todos os nutrientes necessários à criança nos seis primeiros meses de vida, além de ser facilmente digerido e assimilado pelo lactente. É um alimento livre de impurezas, está sempre na temperatura ideal e é muito mais econômico do que as fórmulas industrializadas (XAVIER et al. 1991; CANDELLA 1995).

O leite materno é de fundamental importância para promover um desenvolvimento físico e mental harmônico, além de conferir proteção contra diarréias e mortes por doenças infecciosas no primeiro ano de vida, em particular nos três primeiros meses (KING 2001).

VICTORA et al. (1987), em estudo realizado no Rio Grande do Sul, demonstraram que crianças que recebem leite materno associado a fórmulas ou leite de vaca apresentam risco 4,2 vezes maior de morrer por diarréia do que crianças em aleitamento materno exclusivo. Este risco aumenta para 14,2 vezes para as crianças que não recebem leite materno. Com relação às doenças respiratórias, o risco de morte é 3,6 vezes maior para as crianças que não recebem leite materno.

MONTEIRO et al. (1990) demonstraram um aumento da duração mediana da amamentação no município de São Paulo, entre 1981 e 1987, de 84 para 146 dias, estimando-se que este aumento tenha sido responsável por uma 
redução de $32 \%$ nas taxas de mortalidade infantil por diarréia e de $22 \%$ na taxa de mortalidade por doenças respiratórias.

De acordo com a Academia Americana de Pediatria (AMERICAN 1997), o leite materno diminui a incidência ou a severidade de diarréias, bacteremias, meningites bacterianas, botulismo, enterocolites necrotizantes, doença de Crohn, colites ulcerativas e outras doenças crônico-degenerativas. Há também evidências de proteção contra diabetes mellitus tipo 1 (KARJALAINEN et al. 1992; GIMENO e SOUZA 1998); linfoma e leucemia aguda na infância (DAVIS et al. 1998; BENER et al. 2001); sindrome de morte súbita na infância (FORD et al. 1993); otite média aguda (DUNCAN et al. 1993); asma (ROMIEU et al. 2000; WHRIGHT et al. 2001); proteção a longo prazo contra a sensibilização alérgica (SAARINEN e KAJOSAARI 1995) e possivel proteção contra infecção urinária (PISACANE et al. 1992).

Do ponto de vista psico-afetivo, vários autores referem-se ao ato de amamentar como uma prática que promove importante interação física e psicológica entre mãe e filho (MARCOLINI 1993; KING 2001; LAWRENCE e LAWRENCE 1999 ), facilitando a adaptação da criança ao mundo extra-útero.

Oleitamento materno traz benefícios também para as mães, ajudando a evitar uma nova gravidez através do método da amenorréia da lactação, que consiste na ausência da menstruação e na amamentação exclusiva de seu bebê até seis meses de idade. Menos de $2 \%$ das mulheres que amamentam plenamente engravidam antes de menstruar (KING 2001). A 
amamentação auxilia na redução do sangramento pós-parto (CHUA et al. 1994), e também pode atuar como fator protetor contra osteoporose (BLAWW et al. 1994; JONES et al. 2000); fratura de quadril (CUMMINS e KLINEBERG 1993); artrite reumatóide (BRUN et al. 1995); câncer de mama (HARDY et al. 1993; ZHENG et al. 2000; CHANG-CLAUDE et al. 2000).

ALMEIDA (1999) refere que mais de 150 componentes com suas funções biológicas bem definidas estão presentes no leite materno propiciando benefícios às crianças, porém, o aleitamento materno ultrapassa questões biológicas, quando se verifica através de mecanismos complexos da fisiologia da lactação que marcas biológicas construidas a partir de bases nas matrizes sociais maternas se imprimem no leite materno. Aqui, percebe-se a aproximação do biológico com o social, quando a mãe transfere ao filho, via leite materno, a sua memória imunológica das células de Peyer, relativa aos contatos com agentes enteropatogênicos ao longo de sua vida, regidos por fatores presentes no meio ambiente que refletem características sociais.

Ainda de acordo com esse autor, a memória imunológica é um atributo de qualidade do leite com raízes no social vivido pela mãe e que se contrapõe fortemente ao uso da mamadeira. Enquanto o leite materno protege a criança através de uma herança recebida pela mãe, o uso de mamadeira impõe riscos presentes e futuros.

Em virtude de todos os benefícios que o leite materno traz, a amamentação é a melhor forma de alimentar o lactente. As mães devem ser 
orientadas a amamentar seus filhos integralmente, sem alimentos complementares até o sexto mês de vida. Após esta idade, é necessária a complementação com outros alimentos ricos em ferro, vitaminas e outros nutrientes, mantendo-se preferencialmente o leite materno até 24 meses ou mais (BRASIL 1999; WHO 2001).

A adequação e os benefícios do leite humano estendem-se também para as crianças prematuras, de baixo peso e aquelas a termo que necessitam de internação em unidades de cuidados neonatais.

As peculiaridades funcionais do prematuro, por muitos anos, dificultaram um consenso entre os especialistas sobre a melhor forma de alimentá-los (TOMA 1998).

A partir dos anos 80 , estudos mostraram que o leite de mães de recém-nascidos prematuros apresentam modificações em sua composição (TOMA 1998). Nas primeiras semanas após o parto, este leite, quando comparado ao leite de mães de recém-nascidos a termo, apresenta $30 \%$ a mais de proteínas, $50 \%$ a mais de gorduras, maior concentração de sódio, potássio e cloro; $15 \%$ menos lactose e menor concentração de cálcio e fósforo. Possui uma concentração de IgA secretora 100 vezes maior que o nivel plasmático da mesma, além de fatores antimicrobianos inespecíficos tais como: lisozima, lactoferrina, interferon e uma fração antiviral própria de células do colostro (GONZÁLES et al. 1991). 
Por outro lado, estudos realizados no início dos anos 80 mostram que a composição do leite de mães de prematuros é especifica para estes recém-nascidos, especialmente nas primeiras duas semanas de vida (GROSS et al. 1981; GOLDMAN et al. 1982; LEMONS et al. 1982; BARROS et al. 1984). Tais estudos foram decisivos para que se passasse a recomendar 0 leite da própria mãe para crianças de baixo peso, especialmente nas primeiras semanas de lactação (AMERICAN 1985).

LUCAS e COLE (1990) demonstraram que recém-nascidos prematuros alimentados com fórmulas apresentam chance seis vezes maior de desenvolver enterocolite necrotizante quando comparados a bebês amamentados.

LUCAS et al. (1992) verificaram que bebês prematuros alimentados com leite da própria mãe teriam uma vantagem de 8,3 pontos no quociente de inteligência medido aos 18 meses e aos oito anos de idade, sugerindo que o leite da mãe de recém-nascidos prematuros contém hormônios, fatores tróficos e lipídeos de cadeia longa, os quais podem influenciar na maturação e no crescimento cerebral.

Estudo de WILLIAMS et al. (2001) concluiu que a amamentação beneficia o desenvolvimento da acuidade visual de prematuros, em virtude da presença do ácido docohexaenóico (DHA) no leite materno.

SINGHAL et al. (2001), em pesquisa realizada com uma coorte de crianças entre 13 e 16 anos que nasceram prematuras, verificaram que 
aquelas que foram amamentadas apresentaram menores níveis de pressão arterial e, portanto, com menos riscos de desenvolver doenças cardiovasculares.

De acordo com MOREIRA (1997), na prática clínica a avaliação da adequação do crescimento de prematuros é ainda muito difícil, estando a mesma relacionada ao peso ao nascer, à idade gestacional e ao tipo de leite utilizado para a alimentação do bebê. Muitas vezes, é necessária a interrupção do fornecimento do leite materno para alimentação do prematuro, porque o seu uso se mostra inadequado para um ganho de peso mínimo. Por outro lado, o bebê alimentado com fórmulas artificiais, embora ganhe peso mais rapidamente, apresenta uma composição corporal diferente, demonstrando que o peso como indicador exclusivo pode ser insuficiente. Esta mesma autora afirma que as vantagens do leite materno para recém-nascidos prematuros e de baixo peso têm levado os pesquisadores a considerarem os benefícios do uso do leite humano na prevenção da morbidade relacionada à alimentação, e os resultados a longo prazo relacionados ao desenvolvimento do sistema neural da criança.

TOMA, em 1998, destacou que as fórmulas para prematuros atualmente disponiveis no mercado não representam um substituto à altura do leite humano. Elas contêm muitos componentes em excesso que podem acarretar sobrecarga metabólica, enquanto outros substratos essenciais estão ausentes ou em quantidades insuficientes, podendo levar a distúrbios metabólicos.

Considerando os benefícios relatados, recomenda-se que 
recém-nascidos prematuros e de baixo peso sejam alimentados preferencialmente com leite de suas próprias mães. Entretanto, experiências têm demonstrado a dificuldade dessas mães em manter a amamentação, pois grande parte dos recém-nascidos permanece internada em unidades de cuidados neonatais por longo tempo e sua sucção é deficiente devido à imaturidade deste reflexo ao nascer, além da separação prejudicar a formação do vínculo mãe-filho, fator essencial ao sucesso da amamentação (XAVIER et al. 1991; SILVA et al. 1998; OLIVEIRA et al. 1999).

A coordenação entre a respiração, sucção e deglutição é necessária para que ocorra uma alimentação sadia e segura. Segundo TOMA (1998), bebês maiores de 33-34 semanas de idade gestacional geralmente podem sugar após o nascimento, sendo a alimentação oral o método preferencial, porém, recém-nascidos prematuros necessitam de um período de transição até que adquiram habilidades motoras para a sucção. Durante esta fase a alimentação enteral deverá ser feita por gavagem.

O aleitamento materno é considerado seguro para recémnascidos de baixo peso que apresentam morbidades associadas à prematuridade, uma vez que a manutenção da saturação de oxigênio se dá durante a amamentação pois, fisiologicamente, a amamentação pode ser menos estressante do que a alimentação por mamadeira, principalmente em bebês com displasia pulmonar (BIER et al. 1993).

Neste contexto, é fundamental que as unidades de terapia 
intensiva (UTIs) neonatal busquem experiências comprovadas que possibilitem a amamentação do prematuro e do recém-nascido de baixo peso, com ampla participação da mãe. Exemplo disso é o Cuidado Mãe Canguru, definido como contato pele-a-pele precoce e contínuo entre uma mãe e seu recémnascido de baixo peso, iniciado no hospital e mantido após alta precoce (dependendo das circunstâncias) até pelo menos 40 semanas de idade gestacional pós-natal de forma ideal com amamentação exclusiva e acompanhamento adequado (CATTANEO et al. 1998). Em relação aos benefícios oriundos desta prática, podemos dizer que ela aumenta a prevalência e duração do aleitamento materno; reduz as reinternações, morbidades severas e mortalidade; diminui a necessidade de equipamentos caros e sofisticados; concentra a atenção dos profissionais de saúde para componentes essenciais do cuidado neonatal tais como controle térmico, contato precoce mãe-bebê e amamentação; contribui para o cuidado neonatal e para se estabelecer melhor vínculo entre mãe e filho e por fim, permite que a mãe se torne competente e confiante no cuidado do bebê, tanto no hospital quanto em casa (KENNEL e KLAUS 1998; CATTANEO et al. 1998).

A relação mãe e filho estabelece-se nos primeiros momentos após o parto e nos primeiros dias; portanto, a situação de internação prolongada do recém-nascido, a ansiedade e incerteza da mãe associadas à baixa freqüência de sucção ao seio podem determinar a falência da lactação.

Para a manutenção da lactação das mães de crianças internadas, é fundamental que, além da convivência mãe e filho na maior parte 
do tempo, haja um esvaziamento sistemático das glândulas mamárias por meio de ordenha manual, sendo este leite destinado ao prematuro nos momentos de ausência da mãe (VINHA et al 1988).

Conhecidas as inúmeras vantagens de se propiciar o aleitamento materno o mais precocemente possivel para recém-natos internados em unidades de cuidados intensivos, é necessário que a instituição hospitalar dê apoio a essa prática e procure contornar quaisquer dificuldades através de uma equipe multidisciplinar envolvida com o aleitamento materno. O profissional de saúde deve estar convencido de que todo empenho deve ser feito no sentido de preservar e estimular a amamentação.

No entanto, na maioria das vezes, a realidade é bastante diferente. As unidades de terapia intensiva neonatal contam com profissionais com conhecimentos e habilidade psicomotora fina para assistir recém-nascidos em estado crítico e convictos de que estão prestando assistência altamente sofisticada aos pacientes sob seus cuidados (BELLI 1992). Entretanto, muitos desses profissionais não possuem conhecimentos suficientes sobre aleitamento materno e têm pouca experiência em fornecer apoio às mães no momento da amamentação. Quase sempre ignoram o impacto negativo das rotinas e procedimentos hospitalares sobre o êxito do início e estabelecimento do aleitamento materno. Exemplo disto é a não obediência da Norma Brasileira para Comercialização de Alimentos para Lactentes (NBCAL) por parte dos hospitais que permitem a promoção de leites infantis, seja por cartazes, livretos, brindes ou sacolas promocionais (BRASIL 1994). 
Enfim, muitos são os obstáculos no início do aleitamento, que podem começar em razão da disposição física dos hospitais, das enfermarias obstétricas e a organização de seus serviços, ou ainda em decorrência das atitudes dos profissionais de saúde e outros profissionais que atuam nessas unidades (OMS 1989; RÉA 1990a).

É necessário que esta realidade seja modificada para que o desmame não se inicie já dentro das maternidades, uma vez que o cuidado com os recém-nascidos nos primeiros dias de vida, particularmente o seu modo de alimentação, têm uma influência muito forte sobre o desempenho da lactação materna (OMS 1989).

Neste contexto, o estímulo ao aleitamento materno dentro de UTIs neonatal deve ser entendido como uma alternativa altamente vantajosa do ponto de vista nutricional para o lactente, emocional para a mãe e econômico para a instituição. Porém, há que se considerar que a prática de amamentar, além de ser determinada por fatores biológicos, está condicionada, também, a determinantes socioculturais e a sentimentos maternos vivenciados durante a amamentação. Portanto, a amamentação é infinitamente mais complexa quando comparada com a simples oferta de leite artificial em mamadeira. Por outro lado, prescrever fórmulas lácteas artificiais para bebês internados em UTIs neonatal é bem menos complicado para os profissionais de saúde, se não se levar em conta o custo social desta conduta (BALTAR 1997; ALMEIDA 1999).

Frente às vantagens da amamentação e buscando reverter o 
declínio marcante na prática do aleitamento materno ocorrido após a Segunda Guerra Mundial até o início da década de 70 , programas de incentivo a esta prática apoiados principalmente pela Organização Mundial da Saúde (OMS) e pelo Fundo das Nações Unidas para a Infância (UNICEF) têm sido implementados em vários países nos últimos anos (KUMMER et al. 2000). No Brasil, constata-se uma retomada do aleitamento materno. Nas últimas décadas, houve um aumento nos índices de prevalência da amamentação nos seis primeiros meses de vida graças ao desenvolvimento de políticas de capacitação profissional e a inúmeros trabalhos dirigidos principalmente aos profissionais de saúde, ao público e à industria de leites infantis (RÉA 1990b; VENÂNCIO 1996; MS 1997; MS 2001).

Apesar dos avanços, rotinas hospitalares e conhecimentos insuficientes sobre aleitamento materno ainda influenciam negativamente o êxito do início e estabelecimento do aleitamento, propiciando o desmame dentro das maternidades (RÉA 1990a). Neste contexto, a Iniciativa Hospital Amigo da Criança (IHAC) apresenta-se como uma forma de mobilização dos profissionais de saúde que trabalham em serviços obstétricos e pediátricos em favor da amamentação.

A IHAC é uma estratégia mundial patrocinada pela OMS e UNICEF com o objetivo de promover, proteger e apoiar o aleitamento materno mediante a prática, pelos hospitais, de ações pró-amamentação conhecidas como "Dez passos para o incentivo do Aleitamento Materno". O Brasil foi um dos doze paises escolhidos para colocar em prática a IHAC, firmando este 
compromisso ao assinar a "Declaração de Innocenti" em $1^{\circ}$ de agosto de 1990, em Spedale degli Innocenti, na Itália, durante reunião com um grupo de formuladores de políticas de saúde de governos, agências bilaterais e das Nações Unidas (OMS 1991).

A "Declaração de Innocenti" preconiza e recomenda que sejam adotadas medidas que assegurem nutrição de alta qualidade materna e infantil, bem como sejam estabelecidas políticas nacionais de aleitamento materno inseridas nos programas de assistência à saúde da mulher e da criança (OMS 1991).

De acordo com LEVIN (1999), a IHAC se estabeleceu com o intuito de buscar um equilíbrio no uso da alta tecnologia que, através de aparelhos e artefatos, vem substituindo o aleitamento materno e contribuindo para que a amamentação caia no esquecimento e, a cada vez mais os substitutos do leite materno passem a ser utilizados. Este mesmo autor considera positivo o estabelecimento da IHAC para o resgate do aleitamento materno dentro das maternidades mas, ao mesmo tempo, demonstra preocupação com os bebês patológicos e prematuros que precisam permanecer em unidades de terapia intensiva neonatal. Estes bebês são privados do contato com suas mães e alimentados, na melhor das hipóteses, com leite humano de banco, o que sugere que a IHAC criou uma situação paradoxal: se, por um lado, as rotinas das maternidades estão de acordo com os "Dez Passos", por outro, suas unidades de terapia intensiva neonatal dentro de uma mesma maternidade não respondem às mesmas exigências. 
Muitas instituições hospitalares têm aderido à IHAC, norteando suas ações pró-amamentação pelos "Dez Passos". No Hospital Universitário Regional do Norte do Paraná (HURNP), acredita-se que o processo da IHAC tenha sido uma das ações mais importantes para a mudança da rotina e das práticas hospitalares referentes ao aleitamento materno. Porém, o real impacto desse programa sobre o aleitamento materno dos recém-nascidos patológicos é desconhecido. Assim, esta investigação propôs-se a estudar até que ponto houve uma mudança concreta nas rotinas relativas ao aleitamento materno, contribuindo para a mudança do regime alimentar de recém-nascidos internados na Unidade de Terapia Intensiva (UTI) e Unidade de Cuidados Intermediários (UCl) neonatal do HURNP e influenciaram na duração do aleitamento materno dessas crianças. 


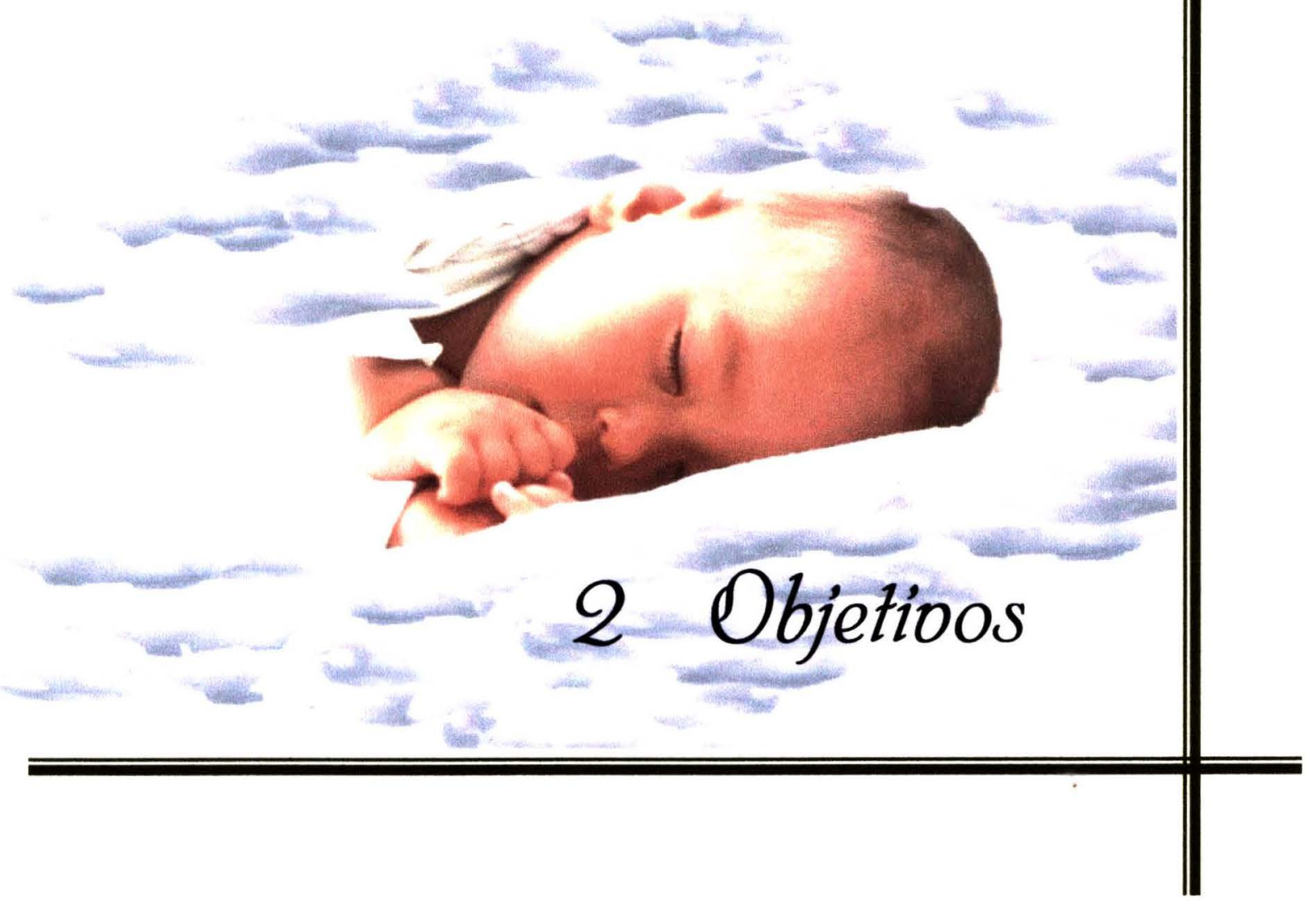




\subsection{Objetivo Geral}

- Avaliar a efetividade da Iniciativa Hospital Amigo da Criança sobre a prática do aleitamento materno dos recém-nascidos internados na Unidade de Terapia Intensiva e Unidade de Cuidados Intermediários do Hospital Universitário Regional do Norte do Paraná.

\subsection{OBJetivos Específicos}

- Descrever as etapas de implantação da Iniciativa Hospital Amigo da Criança no Hospital Universitário Regional do Norte do Paraná.

- Comparar as rotinas relativas à alimentação dos recémnascidos internados na UTI/UCI neonatal, antes do início e ao final do processo de implantação da Iniciativa Hospital Amigo da Criança no Hospital Universitário Regional do Norte do Paraná.

- Comparar a freqüência do aleitamento materno e do aleitamento materno exclusivo durante a internação de pacientes na UTI/UCI neonatal e nos primeiros seis meses de vida, antes e após a implantação da Iniciativa Hospital Amigo da Criança no Hospital Universitário Regional do Norte do Paraná. 


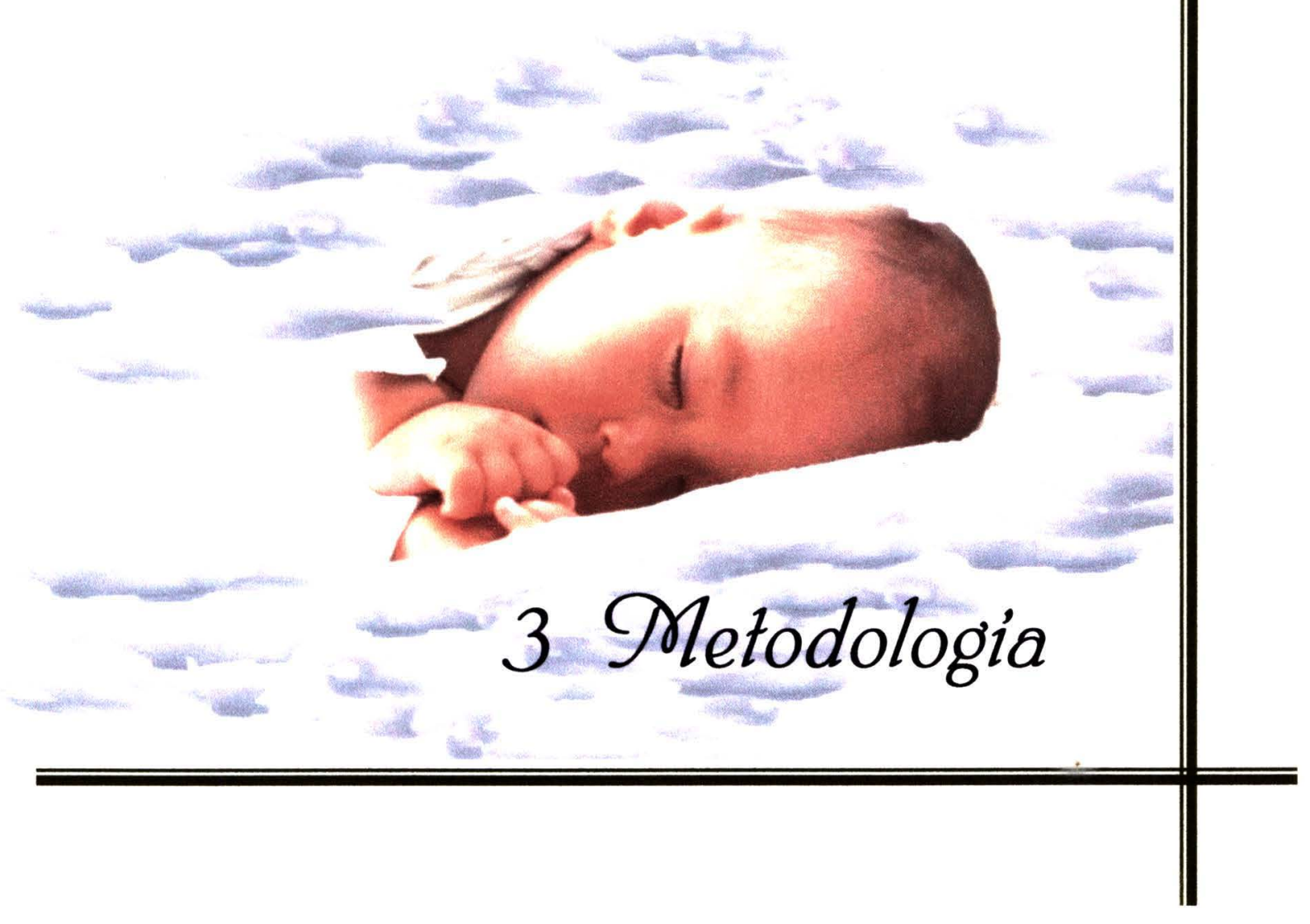




\subsection{LOCAL DE EsTUdO}

\subsubsection{Caracteristicas do Município de londrina e da UNIVERSIDADE ESTADUAL DE LONDRINA}

Londrina é uma cidade de 67 anos, localizada na região norte do Estado do Paraná, sul do Brasil. É a terceira cidade mais povoada do sul do país, com 446.822 habitantes (IBGE 2000). Tem como atividade fundamental a agricultura, porém, o comércio e o setor de serviços são a grande força econômica da cidade, atividades que se estendem a outros municípios do Paraná, sul de São Paulo e leste do Mato Grosso do Sul, uma região com população estimada em 4,5 milhões de habitantes (LONDRINA 2001).

Pela influência no desenvolvimento da cidade, merece destaque a Universidade Estadual de Londrina (UEL), fundada em 1970, que atualmente oferece 38 cursos de graduação e 106 de pós-graduação, atendendo cerca de 15.836 alunos nas diversas áreas do conhecimento (UNIVERSIDADE 2001).

Possui nove centros de estudos, entre os quais o Centro de Ciências da Saúde (CCS), que reúne os cursos de Enfermagem, Farmácia, Fisioterapia, Medicina e Odontologia. O CCS, tem como órgãos suplementares o HURNP, o Ambulatório do Hospital de Clínicas (AHC) e o Centro Odontológico Universitário do Norte do Paraná (COUNP). 


\subsubsection{O Aleitamento materno no Município de Londrina}

O trabalho de estímulo ao aleitamento materno no município de Londrina foi proposto pelos Departamentos Materno Infantil e Saúde Comunitária e de Enfermagem do Centro de Ciências da Saúde da Universidade Estadual de Londrina e teve início na década de 70 , em atividades acadêmicas, de pesquisa e assistenciais, tanto no HURNP quanto na comunidade (THOMSON 1996).

Estudo realizado em 1973/1974 com crianças até dois anos de idade que freqüentavam os ambulatórios do HURNP, revelou que $28,5 \%$ das crianças até dois meses de idade recebiam aleitamento artificial. Este percentual aumentava progressivamente chegando a $73,8 \%$ no grupo de 10 a 12 meses. No grupo de crianças já desmamadas, observou-se que $13,1 \%$ nunca recebeu leite materno e apenas $20,9 \%$ delas recebeu leite materno por tempo superior a três meses (THOMSON 1975).

A partir de 1976 foi implantado o Programa de Estímulo ao Aleitamento Materno (PEAM), que atuou na formação de recursos humanos, aumentando as cargas horárias dedicadas ao estudo do leite materno tanto para os cursos de graduação quanto para os cursos de pós-graduação em Medicina e Enfermagem, além de modificar os cursos preparatórios e de reciclagem para auxiliares de enfermagem que atuavam em Postos de Saúde.

Após quatro anos de implantação desse programa, estudo 
realizado com crianças entre 1 a 12 meses de idade atendidas no HURNP, mostrou que $57,5 \%$ das crianças recebiam Aleitamento Materno Exclusivo (AME) até dois meses e $32,0 \%$ até seis meses de idade (THOMSON et al. 1982). O PEAM atuou ainda no programa de pré-natal do HURNP e das Unidades Básicas de Saúde (UBSs) do município de Londrina, orientando gestantes através de acadêmicos e auxiliares de saúde, baseando-se em rotinas e manuais elaborados especificamente para atender sua finalidade. Ainda no HURNP, teve atuação no puerpério imediato, na maternidade, no puerpério tardio através de visitas domiciliárias e nos ambulatórios de revisão do berçário e de puericultura, onde também foram introduzidas rotinas com ênfase ao aleitamento materno (FAVORETO e THOMSON 1991). Ainda nessa época, foi feita uma revisão das publicações sobre aleitamento materno existentes na biblioteca do CCS e realizadas solicitações sistemáticas a vários órgãos públicos de bibliografias referentes ao tema.

Em 1984, foi institucionalizado no HURNP, o Grupo de Estímulo ao Aleitamento Materno (GEAM), composto por médicos, enfermeiros e assistentes sociais, que passou a desenvolver atividades como representante local da Rede Internacional em Defesa do Direito de Amamentar (IBFAN). Desde que o GEAM foi criado, avaliações periódicas foram realizadas mostrando discreta melhoria dos índices de aleitamento materno. Estudo realizado por FAVORETO e THOMSON (1991) com crianças aos seis meses de vida atendidas nos ambulatórios do HURNP, constatou índices de aleitamento materno de $65,7 \%$ em 1986/1987 e $63,6 \%$ em 1988/1989. 
Em 1987 e 1988 foram publicados dois manuais de rotinas, um sobre a saúde infantil e outro exclusivamente sobre aleitamento materno, editados pela Secretaria Municipal de Saúde e distribuidos em todos os Postos de Saúde do Paraná. Ainda, em 1988, foi implantado no HURNP, o Banco de Leite Humano (BLH), que vem prestando serviços para Londrina e região. Em 1991, a UEL, com o apoio da OMS, editou a tradução em português do livro "Helping Mothers to Breast-feed" de Felicity Savage King, que vem sendo amplamente divulgado em todo o Brasil, e que já está em sua $4^{a}$ edição em português (KING 2001). No mesmo ano, o GEAM passou a colaborar com o setor de Odontopediatria da UEL, através de palestras e discussões com docentes e alunos de pós-graduação, ampliando as atividades de estímulo ao aleitamento materno.

Em 1991, teve início, no CCS, o Projeto UNI Londrina (PROUNI-LD), através de um convênio com a Fundação Kellogg (UEL 1992). Este projeto estimulou a integração da academia com a comunidade e a rede pública de prestação de serviços de saúde da cidade, mantida pela Autarquia do Serviço Municipal de Saúde, e constituída por 52 UBSs, um hospital geral rural e uma maternidade. O PROUNI-LD propiciou o desenvolvimento de atividades junto à comunidade, promovendo discussões periódicas relativas ao aleitamento materno, com lideranças dos bairros mais carentes de Londrina (VANNUCHI et al. 1996).

No final de 1993, foi inaugurada a Maternidade Municipal Lucila Ballalai, onde passaram a atuar alunos dos cursos de graduação em 
Enfermagem e Medicina, além de residentes de pediatria e de ginecologiaobstetrícia, supervisionados por docentes da UEL, membros do GEAM.

Pesquisa realizada em Londrina, em 1994, com crianças abaixo de seis meses de idade no dia nacional de multivacinação, mostrou que $46,6 \%$ estavam em aleitamento materno exclusivo, $23,9 \%$ em aleitamento misto e $30,1 \%$ em aleitamento artificial. Quando se analisou o local de nascimento das crianças, observou-se que as nascidas no HURNP apresentaram melhores índices de aleitamento materno quando comparadas àquelas que nasceram em outros hospitais (OLIVEIRA 1994).

No segundo semestre de 1994, a Autarquia Municipal de Saúde e o Centro de Ciências da Saúde/UEL, entendendo a importância do aleitamento materno na prevenção da mortalidade infantil, criaram o Comitê de Estímulo ao Aleitamento Materno no Município de Londrina (CALMA) com a finalidade de integrar ações de promoção, proteção e apoio ao aleitamento materno no municipio, congregando todas as instituições que trabalham com o tema. Este comitê foi instituído através de um decreto-lei municipal (PREFEITURA 1995).

A partir de 1995, a UEL passou a oferecer assistência multiprofissional às mães com dificuldades e complicações do aleitamento materno, criando a Clínica de Lactação do Ambulatório do Hospital de Clínicas/UEL. Nesse mesmo ano, iniciaram-se os treinamentos dos profissionais do HURNP, AHC e Maternidade Municipal Lucila Ballalai, visando à hạbilitação 
desses serviços como Hospital Amigo da Criança. No final de 1995, a Autarquia Municipal de Saúde implantou o Programa "Unidade Básica Amiga da Criança", considerando que as UBSs exercem papel importante na promoção e manejo do aleitamento materno. Esse projeto foi aprovado pelo Ministério da Saúde (MS) e pela UNICEF (PRANDO e POLI 1997).

Se, por um lado, eram desenvolvidas ações visando o estímulo ao aleitamento materno, de outro, surgia a percepção de que apenas este tipo de incentivo não era suficiente para aumentar os indices de aleitamento. Nesse contexto, merecem menção dois cursos realizados em Londrina. O primeiro, em 1996, da rede IBFAN, sobre Normas de Comercialização de Substitutos do Leite Materno, dirigido a membros do CALMA, Vigilância Sanitária do Municipio e convidados especiais, com o objetivo de proteger o aleitamento materno e o segundo, realizado em 1997 e 1998, sobre Aconselhamento em Amamentação, cuja finalidade era treinar profissionais de saúde envolvidos no cuidado do binômio mãe-filho, nas habilidades necessárias ao manejo da lactação, apoio e proteção ao aleitamento materno.

Essas iniciativas colocaram a cidade em posição de destaque, e Londrina foi escolhida para sediar, em setembro de 1997, o V Encontro Nacional de Aleitamento Materno, que reuniu cerca de 1.100 participantes.

Apesar de todos os esforços desenvolvidos em favor da amamentação em Londrina há três décadas, ainda se observam profissionais de saúde introduzindo precoce e desnecessariamente substitutos do leite materno 
na dieta dos lactentes. Há necessidade de uma coordenação e integração dos diversos grupos de profissionais, o que deverá ocorrer com a concretização do Centro de Referência em Aleitamento Materno de Londrina, que está sendo implantado gradativamente no CCS/UEL. Terá como objetivo atuar na formação de uma cultura em aleitamento materno nas instituições acadêmicas, serviços de saúde e comunidade, constituindo-se em centro de referência para todas as atividades relacionadas ao aleitamento materno (THOMSON 1996).

\subsubsection{Caracteristicas do hospital Universitário}

\section{Regional do Norte do Paraná (HURNP) E}

\section{SUA UnidAdE dE NeONATOlogia}

O HURNP possui 294 leitos, sendo o único hospital público de grande porte de nível terciário do Norte do Paraná, o que o torna centro de referência regional. Possui convênio com a Maternidade Municipal de Londrina, e juntos concentram a maioria dos leitos obstétricos do município, atendendo cerca de $50,0 \%$ dos partos realizados em Londrina. Por ser referência regional, tem a maioria dos 17 leitos de sua maternidade ocupados por gestantes de alto risco, encaminhadas por ambulatórios de pré-natal, consultórios e por outros hospitais de Londrina e região. Pioneiro no Paraná com relação ao alojamento conjunto para recém-nascidos saudáveis, implantado em 1974, e possui uma UTI neonatal com sete leitos e uma UCI neonatal com 10 leitos, desde 1994. 
Depois que o HURNP passou a ser referência para gestantes de alto risco, conforme se esperava, ocorreu diminuição do número de nascimentos de crianças a termo e aumento do número de recém-nascidos internados

\subsection{População de Estudo}

A população enfocada na fase preliminar deste estudo, foi constituida por todos os prontuário de pacientes internados na UTI/UCI neonatal durante os meses de março e abril de cada um dos anos do período 1994 a 1998. A partir dos resultados desse estudo preliminar, optou-se por estudar todos os pacientes internados nessas unidades durante os anos de 1994 $(n=285)$ e $1998(n=368)$. A maioria desses pacientes nasceu no HURNP ( $n=264$ em 1994 e $n=342$ em 1998), os demais nasceram em outros hospitais de Londrina ou região ( $n=21$ em 1994 e $n=26$ em 1998), porém foram encaminhados ao HURNP logo após o nascimento.

Considerando que o enfoque deste estudo é a verificação do impacto da IHAC sobre a prática do aleitamento materno, optou-se por excluir de todas as análises os recém-nascidos que morreram até 48 horas após o nascimento. Essas crianças (17 casos em 1994 e 18 casos em 1998) apresentavam quadros clinicos extremamente graves o que impedia qualquer tipo de alimentação não parenteral. 


\subsection{Aprovacão pelo Comitê de Ética em Pesquisa}

Atendendo a Resolução $\mathrm{n}^{\circ}$ 196, de 10 de outubro de 1996, do Conselho Nacional de Saúde, que dispõe sobre as normas regulamentadoras de pesquisa com seres humanos (BRASIL 1997), o projeto desta pesquisa foi analisado e aprovado pelo Comitê de Ética em Pesquisa da Faculdade de Saúde Pública da USP, conforme parecer Of.COEP/197/99, de 08/10/99 (Anexo 1). Foi também analisado e aprovado pelo Comitê de Ética em Pesquisa da UEL, de acordo com o Parecer Bioética nº 040/99 de 23/08/99 (Anexo 2).

Obtidas as aprovações, foi encaminhado ofício à Direção Clínica do HURNP (Anexo 3) e Chefias Médica e de Enfermagem da Unidade de Neonatologia do HURNP (Anexo 4), solicitando autorização para a coleta de dados. Todas permitiram, sem restrições, acesso aos dados.

Vale ressaltar que o titulo do projeto de pesquisa encaminhado a todas as instâncias necessárias à sua aprovação, foi modificado uma vez que ao final da pesquisa este título não contemplava a abrangência do estudo.

\subsection{Fontes DE Dados}

As fontes de dados utilizadas foram primárias e secundárias. As primárias constaram de entrevistas com profissionais de saúde do Setor de Neonatologia do HURNP. 
As fontes secundárias de dados constituiram-se de:

- Documentos e registros existentes no HURNP sobre a implantação/implementação da IHAC.

- Prontuários dos recém-nascidos internados na UTI e UCI neonatal do HURNP durante os meses de março e abril no periodo de 1994 a 1998.

- Prontuários dos recém-nascidos internados na UTI e UCI neonatal do HURNP durante os anos de 1994 e 1998, incluindo informações sobre o regime alimentar após a alta hospitalar até os primeiros seis meses de vida.

\subsection{Coleta de Dados}

A coleta de dados foi feita em três etapas.

Na primeira etapa, coletaram-se dados de uma amostra dos pacientes internados na UTI e UCl neonatal, em cada um dos anos do período 1994 a 1998, selecionando-se os pacientes internados nos meses de março e abril de cada ano. Os prontuários desses pacientes foram analisados quanto ao tipo de leite a eles oferecido durante o período de internação e com base nos achados, decidiu-se centrar o estudo nos anos extremos do período 1994 a 
1998, ou seja em 1994 (ano anterior ao início do processo da IHAC no HURNP) e 1998 (ano em que a comissão executiva da IHAC no HURNP julgou cumprido os "Dez Passos" e solicitou a pré-avaliação pela Secretaria de Saúde do Estado do Paraná - SESA).

$\mathrm{Na}$ segunda etapa, coletaram-se dados referentes a todos os pacientes que foram internados na UTI e UCI neonatal durante os anos de 1994 e 1998. A coleta foi feita a partir dos prontuários dos pacientes, seguindo um roteiro elaborado especificamente para a pesquisa (Anexo 5). As informações coletadas foram posteriormente transferidas para um banco de dados eletrônico.

Além da análise dos prontuários, foram consultados e analisados todos os documentos e registros referentes ao processo de implantação/implementação da IHAC no HURNP.

Nessa fase da coleta, a pesquisadora contou com o auxílio de cinco estudantes do curso de graduação em Enfermagem da UEL, previamente treinadas.

A terceira e última etapa da coleta de dados constou de entrevistas com oito profissionais de saúde do Setor de Neonatologia, previamente selecionados por terem trabalhado na UTI e/ou UCI neonatal do HURNP durante os anos de 1994 e 1998. Esses profissionais foram considerados informantes-chave, ou seja, pessoas bastante familiarizadas com o fenômeno de interesse da pesquisa e com desejo de partilhar as informações com a pesquisadora (POLIT e HUNGLER 1995). 
As entrevistas foram feitas a partir de um roteiro (Anexo 6), que propiciava aos profissionais discorrerem sobre a rotina de aleitamento materno na UTI/UCI neonatal do HURNP, antes e após a implementação da IHAC. Os depoimentos dos entrevistados foram citados no texto com o objetive de caracterizar as diferenças das rotinas referentes ao aleitamento materno na UTI/UCI neonatal antes e após a implantação da IHAC no HURNP, portanto, não se utilizou nenhum procedimento para análise desses depoimentos indicados na literatura que aborda pesquisa qualitativa. Todas as entrevistas foram gravadas e posteriormente transcritas em sua integra, sempre com a aprovação escrita do entrevistado (Anexo 7).

$\mathrm{Na}$ apresentação dos depoimentos, utilizou-se a inicial da palavra "entrevistado" (E), seguida do número da entrevista, para assegurar o anonimato dos participantes.

\subsection{Variáveis de Estudo e Categorização}

a) SEXO

- feminino

- masculino

- sem registro

b) Data de nascimento e da Alta hospitalar 


\section{c) Peso ao nascer}

Considerado peso ao nascer a primeira verificação do peso do recém-nascido feita após o nascimento:

$$
\begin{aligned}
& >\quad<1500 \mathrm{~g} \\
& -1500 \vdash 2499 \mathrm{~g} \\
& -2500 \mathrm{~g} \text { e mais }
\end{aligned}
$$

\section{d) ÍNDICE DE APGAR}

Foi verificado o Índice de Apgar no primeiro e no quinto minuto de vida, conforme anotação no prontuário do recém-nascido.

- $0 \longmapsto 3$ (gravemente anoxiado)

- $4 \longmapsto 7$ (anóxia neonatal moderada)

- $8 \longmapsto 10$ (boas condições de vitalidade)

- sem registro

\section{e) Classificação da Maturidade}

A maturidade do recém-nascido foi classificada pelo método de Capurro, adotando-se as seguintes categorias: 
- Pré-termo: < 37 semanas de gestação

- A termo: $37 \longmapsto 42$ semanas de gestação

- Pós-termo: > 42 semanas de gestaçäo

f) Classificação do Crescimento INTRA-Uterino (Peso / Idade Gestacional)

- PT/AIG (Pré-termo, adequado para idade gestacional)

- PT/PIG (Pré-termo, pequeno para idade gestacional)

- PT/GIG (Pré-termo, grande para idade gestacional)

- AT/AIG (A termo, adequado para idade gestacional)

- AT/PIG (A termo, pequeno para idade gestacional)

- AT/GIG (A termo, grande para idade gestacional)

- Pós-termo/AIG (Pós-termo, adequado para idade gestacional)

- Pós-termo/PIG (Pós-termo, pequeno para idade gestacional)

- Pós-termo/GIG (Pós-termo, grande para idade gestacional)

- Não foram classificadas

\section{g) DuRAÇÃo da INTERnAÇÃo do RECÉM-NASCIdo}

- menos de $24 \mathrm{~h}$

- $1 \longmapsto 5$ dias

- $6 \longmapsto 10$ dias

- $11 \longmapsto 15$ dias 
- $16 \longmapsto 20$ dias

- $21 \longmapsto 25$ dias

- $26 \longmapsto 30$ dias

- $31 \longmapsto 35$ dias

- 36 dias e mais

h) Regime AlimentaR DURANTE a INTERnAÇÃo

Refere-se ao tipo de regime alimentar que o recém-nascido recebeu durante o tempo de internação logo após o nascimento. Foram definidas as seguintes categorias de regimes alimentares:

\section{h.1) Leite Humano Exclusivo}

Situação na qual o recém-nascido recebeu, durante toda a internação, somente leite humano de sua própria mãe e/ou do banco de leite. Esta categoria foi sub-dividida em:

- Leite só da mãe

- Leite só do banco de leite

- Leite da mãe + leite do banco

\section{h.2) FóRmula Exclusiva}

Situação na qual o recém-nascido tenha recebido somente fórmula, durante toda a internação. 


\section{h.3) Leite Humano + Fórmula}

Situação na qual o recém-nascido recebeu, durante a internação, leite humano (da mãe e/ou do banco) e fórmula. Esta categoria foi sub-dividida em:

- Leite da mãe + fórmula

- Leite do banco + fórmula

- Leite da mãe + leite do banco + fórmula

\section{i) Regime Alimentar Após a Alta hospitalar}

Refere-se ao tipo de regime alimentar que a criança recebeu após a alta hospitalar até os primeiros seis meses de vida. Foram definidas as seguintes categorias de regimes alimentares:

- Aleitamento materno exclusivo (AME): alimentação exclusiva com leite da própria mãe e/ou do banco de leite humano.

- Aleitamento materno (AM): alimentação com leite da própria mãe elou do banco de leite complementada por outros alimentos.

- Aleitamento artificial (AA): alimentação somente com leite artificial.

\section{j) Procedência materna}

- Londrina

- Região 


\subsection{Procedimentos Analíticos}

Os dados coletados na pesquisa foram categorizados e digitados em um banco de dados estruturado no programa Epi-Info versão 6.0b (DEAN et al. 1995).

Para a análise dos dados foram calculadas médias e desvios padrão para as variáveis quantitativas e porcentagens para as variáveis qualitativas. Os dados foram apresentados de forma a permitir comparação entre os grupos de crianças internadas em 1994 e 1998. Para verificar a igualdade das médias entre os grupos, utilizou-se o teste $\mathrm{t}$ de Student ou teste de KruskalWallis e, para verificar a homogeneidade na distribuição das variáveis qualitativas, utilizou-se o teste do Qui-quadrado e, na impossibilidade deste, utilizou-se o teste exato de Fisher. Todos estes testes foram realizados pelo programa Epi-Info.

Para a análise do aleitamento, durante o periodo de internação, comparou-se a prevalência do AM e do AME entre os recém-nascidos internados na UTI/UCI neonatal em 1994 e 1998. Foram comparadas prevalências brutas e prevalências ajustadas para as variáveis cuja distribuição tivesse alterado significativamente entre 1994 e 1998 empregando-se para tanto regressão logística conduzida por meio do programa SAS (SAS 1989).

Para estimar o tempo de duração do AM e do AME nos primeiros seis meses de vida das crianças internadas em 1994 e 1998 utilizou-se a 
técnica de Kaplan-Meier. Para avaliação do significado estatístico de diferenças na duração do AM e AME entre os dois grupos de estudo, utilizou-se o teste Log-Rank realizado pelo programa Statistica for Windows (STATSOFT 2000). Comparações que levam em conta alterações significativas entre 1934 e 1998 na distribuição de possíveis variáveis de confusão foram realizadas empregando-se o método de regressão de Cox por meio do programa SAS. Nesse modelo de regressão o AME e $~ A M$ foram considerados como variáveis dependentes e como variáveis independentes considerou-se: Ano (1 = 1994 e $2=1998) ; \quad$ Precedência (1 = região e $2=$ Londrina $) ;$ Peso ao nascer/IG $(1=$ pequeno e $2=$ adequado + grande $)$; Apgar no $1^{0}$ minuto $(1=$ até 7 e $2=8$ ou +$) ;$ Apgar no $5^{0}$ minuto $(1=$ até 7 e $2=8$ ou +$)$ e Tempo de internação ( 1 = até 10 e $2=1$ ou +$)$.

Em todos os testes adotou-se o nível de $5,0 \%$, ou seja, todos os testes que apresentaram niveis descritivos menores que $0,05(p<0,05)$ foram considerados estatisticamente significantes. 


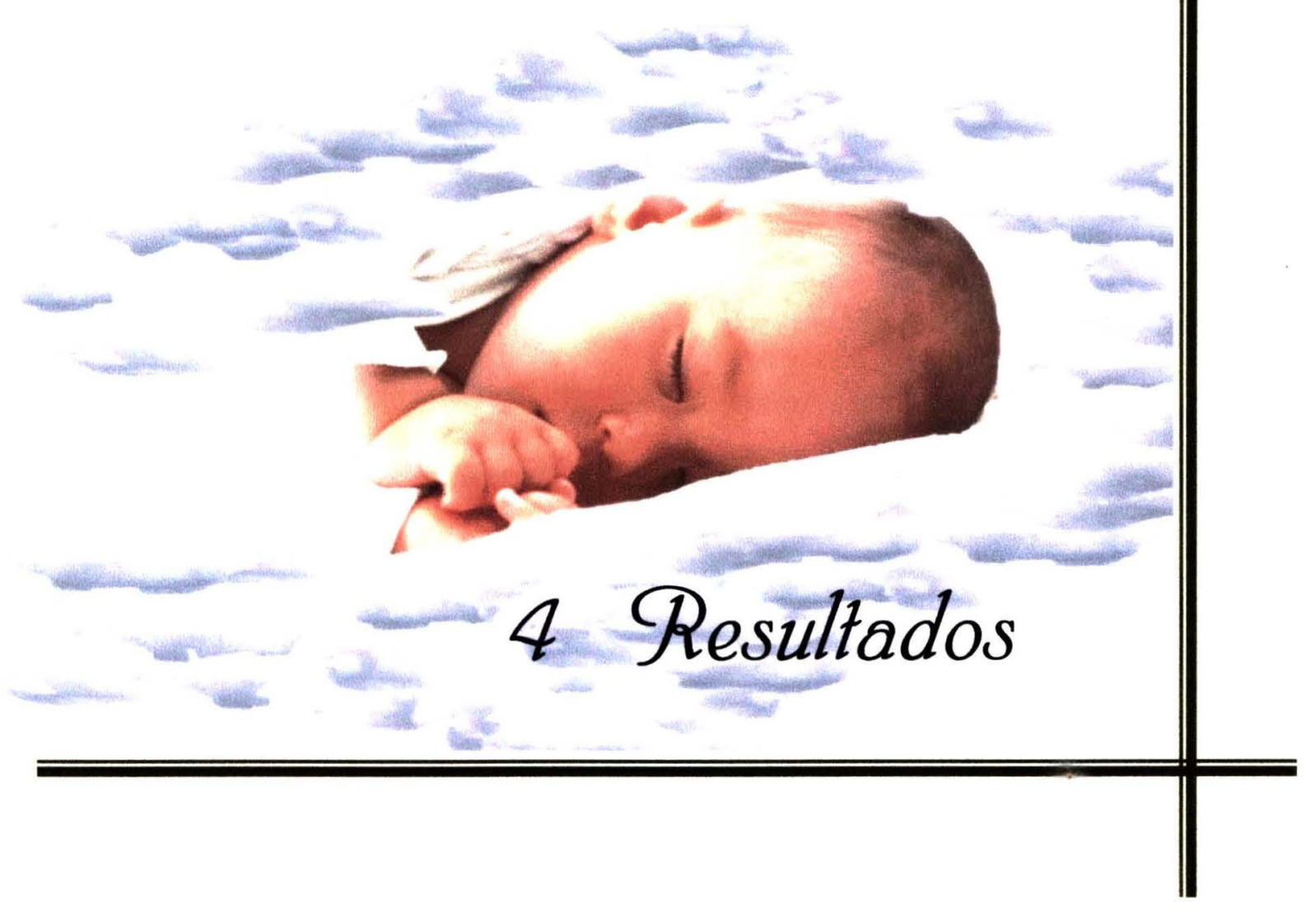




\subsection{ETAPAS dA IMPLANTAÇÃo dA INICIATIVA dO HOSPITAL AMigo da CRIANÇa No HURNP}

Até 1994, apesar de inúmeras iniciativas relativas à promoçao ao aleitamento materno em Londrina e, em especial no HURNP, parte das crianças nascidas nesse hospital continuava recebendo fórmulas em substituição ao leite materno. Esta situação levou profissionais da área materno-infantil do HURNP à decisão de reavaliar e reestruturar as rotinas e procedimentos referentes ao aleitamento materno no hospital e de buscar a prática dos "Dez Passos" preconizados pela IHAC, visando o sucesso da amamentação. Em 1995 inicia-se o processo de implantação da IHAC no HURNP.

A primeira etapa da implantação foi a realização, em março de 1995, de um inquérito para avaliar o cumprimento pelo HURNP dos "Dez Passos" preconizados pela IHAC. Esse inquérito revelou que o HURNP ainda estava distante de poder pleitear a qualificação de "Hospital Amigo da Criança" (THOMSON et al. 1995).

Frente ao resultado do inquérito, em abril de 1995, a direção do hospital nomeou o grupo de implantação da Iniciativa Hospital Amigo da Criança, composto por enfermeiros, médicos, fisioterapeuta, nutricionista e assistente social. Este grupo multiprofissional responsabilizou-se por desenvolver estratégias voltadas à implantação e implementação da IHAC no HURNP.

Inicialmente, o grupo era numeroso mas, com o decorrer do 
4 Resultados

tempo, ficou constituído principalmente pelas pessoas mais comprometidas com o processo de mudanças. O trabalho de implantação/implementação da IHAC ocorreu durante três anos e, no final de 1997, o grupo julgou oportuna a realização de uma nova avaliação para verificar o cumprimento dos passcs da IHAC. Dessa forma, solicitou à SESA o envio de avaliadores ao HURNP para que se efetuasse a primeira pré-avaliação. Essa avaliação, realizada no início de setembro de 1999, com base no questionário de auto avaliação dos hospitais, mostrou o efetivo cumprimento dos "Dez Passos" pelo HURNP. A etapa seguinte da implantação ocorreu no final setembro de 1999 , quando então a SESA enviou ao Ministério da Saúde o resultado da pré-avaliação, acompanhado de pedido de nova avaliação. O MS enviou, no início de abril de 2000, dois avaliadores que realizaram a última avaliação, utilizando como instrumento um questionário de avaliação global de hospitais, instrumento fornecido pelo próprio MS (BRASIL 1992b). No final de abril de 2000, o HURNP foi credenciado pelo MS, e recebeu a placa de "Hospital Amigo da Criança" em setembro de 2000.

O Quadro 1 apresenta um resumo das etapas da implantação da IHAC no HURNP. 
4 Resultados

QUADRO 1 - Etapas desenvolvidas para a implantação da IHAC no HURNP.

\begin{tabular}{|c|c|}
\hline ETAPAS & DATAS \\
\hline $\begin{array}{l}\text { 1. Diagnóstico da situação do HURNP com relação aos } \\
\text { Dez Passos da IHAC }\end{array}$ & março de 1995 \\
\hline $\begin{array}{l}\text { 2. Formação do grupo de implantação da IHAC e início } \\
\text { das atividades }\end{array}$ & abril de 1995 \\
\hline $\begin{array}{l}\text { 3. Solicitação à SESA para pré-avaliação dos Dez } \\
\text { Passos }\end{array}$ & dezembro de 1997 \\
\hline 4. Realização da pré-avaliação pela SESA & setembro de 1999 \\
\hline $\begin{array}{l}\text { 5. Encaminhamento ao MS do resultado da pré- } \\
\text { avaliação dos Dez Passos, realizada pela SESA }\end{array}$ & setembro de 1999 \\
\hline $\begin{array}{l}\text { 6. Avaliação dos Dez Passos da IHAC no HURNP, pelo } \\
\text { MS }\end{array}$ & abril de 2000 \\
\hline $\begin{array}{l}\text { 7. Credenciamento do HURNP como "Amigo da } \\
\text { Criança", pelo MS }\end{array}$ & abril de 2000 \\
\hline $\begin{array}{l}\text { 8. Entrega da placa de "Hospital Amigo da Criança" ao } \\
\text { HURNP }\end{array}$ & setembro de 2000 \\
\hline
\end{tabular}

\subsection{Rotinas Sobre a Prática do Aleitamento Materno NO H U R N P, ANTES E APÓS A IMPLANTAÇÃo da InICIATIVA Hospital AMIGO dA CRIANÇA}

$\mathrm{Na}$ investigação dos documentos e registros existentes no HURNP sobre a implantação/implementação da IHAC, foram analisados os resultados de dois inquéritos que tiveram como objetivo verificar o cumprimento dos "Dez Passos". O primeiro inquérito foi realizado no início de 1995, antes da implantação da IHAC (THOMSON et al. 1995), e o segundo no final de 1998 
(SENTONE e THOMSON, 2000). Ambos os inquéritos foram realizados por profissionais de saúde integrantes do grupo de implantação/implementação da IHAC no HURNP, e tiveram como base o questionário de auto-avaliação de hospitais fornecido pelo MS (BRASIL 1992a). Para cada um dos "Dez Passos" foi definida uma forma de avaliação, incluindo análise crítica das rotinas, levantamento de prontuários de recém-nascidos para verificar o tipo de alimentação recebida durante a internação e aplicação do questionário a gestantes, puérperas e profissionais de saúde do ambulatório de pré-natal, maternidade, UTI e UCI neonatal do HURNP.

O Quadro 2 apresenta um resumo dos resultados dos inquéritos realizados no HURNP, antes e após a implantação da IHAC. 
QUADRO 2 - Comparação do cumprimento dos "Dez Passos" pelo HURNP antes (1995)* e após (1998)** a implantação da IHAC.

\begin{tabular}{|c|c|c|c|}
\hline \multirow{2}{*}{\multicolumn{2}{|c|}{ PASsOS }} & \multicolumn{2}{|c|}{ CUMPRIMENTO DOS PASSOS } \\
\hline & & 1995 & 1998 \\
\hline 1 & $\begin{array}{l}\text { Ter norma escrita sobre AM, que deve ser } \\
\text { rotineiramente transmitida à equipe de } \\
\text { saúde }\end{array}$ & Não & Sim \\
\hline 2 & $\begin{array}{l}\text { Treinar toda a equipe de cuidados de } \\
\text { saúde, capacitando-a para implementar } \\
\text { esta norma }\end{array}$ & $\begin{array}{c}\text { Parcial } \\
(10,0 \% \text { da equipe })\end{array}$ & $\begin{array}{l}\text { Parcial } \\
\text { (90,0\% da } \\
\text { equipe) }\end{array}$ \\
\hline 3 & $\begin{array}{l}\text { Informar todas as gestantes sobre as } \\
\text { vantagens e o manejo do aleitamento }\end{array}$ & $\begin{array}{l}\text { Parcial } \\
\text { (10,0\% das } \\
\text { gestantes) }\end{array}$ & $\begin{array}{l}\text { Total } \\
\text { (100,0\% das } \\
\text { gestantes) }\end{array}$ \\
\hline 4 & $\begin{array}{l}\text { Ajudar as mães a iniciar a amamentação } \\
\text { na primeira meia hora após o parto }\end{array}$ & Não & Sim \\
\hline 5 & $\begin{array}{l}\text { Mostrar às mães como amamentar e } \\
\text { manter a lactação, mesmo se vierem a ser } \\
\text { separadas de seus filhos }\end{array}$ & $\begin{array}{c}\text { Parcial } \\
(6,7 \% \text { das mães })\end{array}$ & $\begin{array}{l}\text { Total } \\
(100,0 \% \text { das } \\
\text { mães })\end{array}$ \\
\hline 6 & $\begin{array}{l}\text { Não dar a recém-nascidos nenhum outro } \\
\text { alimento ou bebida além do leite materno, } \\
\text { a não ser que seja indicado pelo médico }\end{array}$ & $\begin{array}{c}\text { Parcial } \\
(6,7 \% \text { dos RNs em } \\
\text { AME) }\end{array}$ & $\begin{array}{c}\text { Parcial } \\
(80,2 \% \text { dos } \\
\text { RNs em AME) }\end{array}$ \\
\hline 7 & $\begin{array}{l}\text { Praticar o alojamento conjunto - permitir } \\
\text { que mães e bebês permaneçam juntos } \\
24 \mathrm{~h} \text { por dia }\end{array}$ & $\begin{array}{c}\text { Parcial } \\
(50,0 \% \text { - Parto Normal }) \\
(100,0 \% \text { - Cesária })\end{array}$ & $\begin{array}{l}\text { Total } \\
(100,0 \% \text { dos } \\
\text { RNs })\end{array}$ \\
\hline 8 & Encorajar o aleitamento sob livre demanda & $\begin{array}{c}\text { Parcial } \\
(6,7 \% \text { das mães })\end{array}$ & $\begin{array}{l}\text { Total } \\
(100,0 \% \text { das } \\
\text { mães })\end{array}$ \\
\hline 9 & $\begin{array}{l}\text { Não dar bicos ou chupetas a crianças } \\
\text { amamentadas ao seio }\end{array}$ & $* * *$ & $\begin{array}{l}\text { Total } \\
(100,0 \% \text { dos } \\
\text { RNs })\end{array}$ \\
\hline 10 & $\begin{array}{l}\text { Encorajar a formação de grupos de apoio } \\
\text { à amamentação para onde as mães } \\
\text { devem ser encaminhadas, logo após a alta } \\
\text { do hospital ou ambulatório****}\end{array}$ & $\begin{array}{c}\text { Parcial } \\
\text { (esporádico ao BLH) }\end{array}$ & $\begin{array}{l}\text { Total } \\
(100,0 \% \text { das } \\
\text { mães })\end{array}$ \\
\hline
\end{tabular}

Fontes: *Thomson, Vannuchi e Melanda, 1995.

**Sentone e Thomson, 2000.

*** A avaliação deste passo ficou prejudicada em função do período de transição para a rotina do uso do "copinho".

**** Não existem grupos de apoio comunitários em Londrina. O cumprimento do passo foi avaliado considerando-se o encaminhamento das mães aos serviços de apoio do HURNP. 
Vale ressaltar que ambos os inquéritos apresentados no Quadro 2, fizeram parte do processo de implantação da IHAC no hospital, portanto, os resultados nele apresentados referem-se a todas as unidades onde os questionários foram aplicados e não somente à UTI e à UCI neonatal.

A seguir serão apresentadas as mudanças de rotinas sóbre a prática do aleitamento materno, primeiramente no hospital como um todo, e na seqüência, na UTI e UCI neonatal, unidades de interesse desta pesquisa. Os dados serão apresentados seguindo os "Dez Passos".

- Passo 1: Ter uma norma escrita sobre aleitamento, que Deve ser Rotineiramente Transmitida a Toda a Equipe de Cuidados de SAÚde

No início de 1995 , de acordo com resultados do primeiro inquérito, não havia norma especifica sobre aleitamento materno na UTI/UCI neonatal do HURNP. O que existia era um material bastante volumoso intitulado “Normas, Técnicas e Rotinas do Setor de Enfermagem dA Unidade de NeOnatologia" que continha todas as normas, técnicas e rotinas para a organizaçăo das atividades desenvolvidas no setor, dirigido aos três turnos de trabalho. A técnica de AM encontrava-se descrita junto às demais, sem destaque para tal procedimento.

Existia também no setor de neonatologia, uma rotina médica de orientação para a alimentação do recém-nascido, indicando o estímulo ao AM 
sempre que possivel. Este material servia de referência para os alunos dos cursos de graduação e pós-graduação em enfermagem e medicina.

Constatou-se desconhecimento destas normas por parte dos profissionais entrevistados os quais se referiram ao aparecimento de norma específica sobre AM somente após o desencadeamento do processo da IHAC, como mostram os seguintes relatos:

Existia dentro do esquema de alimentação do recém-nascido, existia que o ideal é o leite materno, suas vantagens, isto fazia parte de orientação das mães no momento da alta. Fazia parte da rotina médica para orientações de estudantes e residentes. Foi criada especificamente para o AM após a IHAC (E8).

No início da UTI neonatal não existiam normas sobre $A M$. Aparece a partir de quando eles começaram a dar os cursos da IHAC (E1).

Existia pouquíssima coisa. Existiam orientações focadas em pessoas mas não existia como normatização do setor que favorecesse o AM. Esta norma aparece a partir do momento que a instituição resolve entrar no processo da IHAC (E2).

Após a IHAC foram implantadas normas e rotinas especificas sobre AM na UTI e UCI neonatal, sala de parto e maternidade conforme resultado demonstrado no inquérito de 1998. 


\section{- Passo 2: treinar toda a Equipe de Cuidados de saúde, Capacitando-A para Implementar esta Norma}

Quanto ao treinamento da equipe, o inquérito realizado em 1995 revelou que apenas $10,0 \%$ dos funcionários haviam recebido treinamento específico sobre AM. Já em 1998, $90,0 \%$ da equipe havia sido treinada, porém, com relação à UTI/UCI neonatal, toda a equipe havia recebido treinamento. $O$ processo de treinamento coletivo foi desencadeado somente após a IHAC, como mostram as falas de alguns profissionais entrevistados:

No início da IHAC eu fiz um curso com duração de duas semanas, ai fizemos também uma visita ao serviço de AM de Santos. $O$ treinamento acrescentou conteúdo novo para mim porque eu sabia orientar a prática mas não sabia a fundamentação daquilo que eu explicava para a mãe, mas o treinamento foi dado após a IHAC (E1).

O treinamento só se deu após a IHAC e acrescentou bastante, porque as informações recebidas no curso fazem você refletir a sua prática (E2).

Eu recebi treinamento de 18 horas no inicio do processo da IHAC e hoje eu treino outros profissionais porque eu dou aula nos cursos da IHAC (E8). 


\section{- Passo 3: Informar todas as Gestantes sobre as Vantagens} e o manejo do aleitamento

O inquérito realizado em 1995 mostrou que as orientações daadas às mães no pré-natal eram insuficientes e atingiam um número muito pequeno de mães $(10,0 \%)$. Já o segundo inquérito revelou que todas as mães recebiam orientações no pré-natal.

Repostas oriundas das entrevistas feitas com os profissionais do setor de neonatologia, revelam que as mães de recém-nascidos internados no setor de terapia intensiva assimilam melhor as informações recebidas por ocasião do internamento de seu filho, quando orientadas no pré-natal. Abaixo, alguns exemplos:

A mãe que vem de um serviço que tem este passo é mais fácil trabalhar com ela, ela já vem mais esclarecida então você só vai reforçar o conhecimento sobre AM que ela já tem (E4).

É fundamental que a gente discuta as informações que são recebidas antes do nenezinho nascer, porque tem o stress do parto ou do nenezinho nascer doente ou prematuro e tudo isto faz com que ela tenha uma captação menor das informações (E3). 


\section{- Passo 4: Ajudar as mães a iniciar a Amamentação na Primeira} HORa Após o Parto

O primeiro inquérito mostrou que, no início de 1995 , este passo não era obedecido. Nos casos de parto normal, apenas uma criança havia sido amamentada com menos de três horas após o nascimento, enquanto $70,0 \%$ haviam sido amamentadas com mais de seis horas de vida. Nos casos de cesariana, todas as crianças haviam sido amamentadas com mais de oito horas de vida. Apenas $20,0 \%$ das mães disseram ter recebido orientações sobre o início da amamentação. O inquérito de 1998 revelou que todas as mães e recém-nascidos em boas condições de vitalidade, haviam recebido ajuda para iniciar a amamentação na primeira meia hora de vida.

A maioria dos profissionais entrevistados disse que este passo é difícil de ser aplicado com relação às mães de recém-nascidos graves, que necessitam de internação em unidade de terapia intensiva, de acordo com as falas abaixo:

Dificilmente o bebê que nasce grave é colocado para sugar na sala de parto... (E4).

... a criança que vai para a UTI não tem condições de mamar na sala de parto. Mas acho que essa rotina implantada na sala de parto, mantém a conscientização dos funcionários sobre a importância desse passo, além de sabermos que a descida do leite é diretamente proporcional à ordenha precoce... (E8). 


\section{- Passo 5: Mostrar às mães como amamentar e como mantero} Processo de lactação, Mesmo se Vierem a ser Separadas de SEUS FILHOS

No primeiro inquérito, $93,3 \%$ das mães informaram não ter recebido as orientações contidas no Passo 5, quando separadas de seus filhos. Por outro lado, no segundo inquérito, todas as mães separadas de seus filhos disseram ter recebido essas orientações.

Este passo é de fundamental importância para o aleitamento das crianças que necessitam de internação logo após o nascimento. As respostas dos profissionais entrevistados confirmaram que ele passou a ser praticado na UTI e UCI neonatal do HURNP após a implantação da IHAC, conforme mostram as falas abaixo:

Antes da IHAC as mães iam embora e não amamentavam mesmo, porque elas deixavam o bebê e não eram orientadas como manter a produção láctea delas e, quando voltavam para buscar o bebê na alta elas diziam que não tinham mais leite (E4).

Com a vinda da IHAC passa a existir um trabalho de mudança de comportamento de como orientar esta mãe que está separada de seu filho, ou seja, esta mãe mesmo impossibilitada de ter o primeiro contato com seu filho na sala de parto, de iniciar precocemente a lactação, ela é orientada a fazer a ordenha manual desta mama para que este estímulo seja precocemente instalado e o processo de lactação ocorra mesmo a criança estando sem a mãe (E2). 


\section{- Passo 6: não dar ao Recém-Nascido nenhum Outro alimento ou Líquido Além do Leite Materno, a Não Ser que Seja Indicado PELO MÉdICO}

O primeiro inquérito evidenciou o descumprimento total deste passo pois, de acordo com a maioria dos prontuários médicos, o leite artificial foi ministrado sem prescrição médica e raras foram as justificativas encontradas nos prontuários para não usar o leite materno. Somente $6,7 \%$ das crianças encontravam-se em AME. Em 1998, essa situação se altera, e todos os casos de crianças que receberam outro alimento ou líquido diferente do leite materno foram justificados, conforme anotação constante em prontuário. Das crianças pesquisadas no segundo inquérito, $80,2 \%$ encontravam-se em AME.

As entrevistas feitas com profissionais do Setor de Neonatologia confirmaram a situação descrita acima. Quando questionados sobre o tipo de leite oferecido aos recém-nascidos internados na UTI ou UCI antes da IHAC, a maioria respondeu que era o artificial, de acordo com os relatos abaixo:

Dava Pré-nan e Nan. Leite materno ou do banco, eram raros (E5).

Era quase unanimidade o uso de fórmulas lácteas. O que era muito prescrito era o Nan, não existia conscientização de estar incentivando o $A M(\mathrm{E} 2)$. 
Na prática era dado o Pré-nan e o Nan (E1).

No periodo pós implantação da IHAC, todos disseram que a primeira opção é o leite materno, a segunda é o leite do BLH e, por último, a fórmula com justificativa médica. A seguir, algumas falas que ilustram, essa situação:

Hoje após a IHAC, é o inverso que ocorre; vem leite da própria mãe e o complemento é o leite do BLH, isto na primeira semana $e$ após só leite da mãe quando esta tiver a sua produção aumentada (E7).

Após a IHAC se prescreve leite da própria mãe ou banco $e$ também é checado se aquilo que foi prescrito é aquilo que foi dado... (E8).

Com a vinda da IHAC, passou a existir uma norma que a gente segue no sentido de incentivar o AM desde a sala de parto. No caso de alguma criança que por algum motivo esteja impossibilitada de praticar o AM, a primeira opção é o leite do BLH e em última instância usa-se fórmula (E2). 


\section{- Passo 7: Praticar o alojamento conjunto - Permitir que a mãe e Bebê Permaneçam Juntos 24 horas por Dia}

O primeiro inquérito revelou que, até o início de 1995, tocios os recém-nascidos de parto cirúrgico, em boas condições de vitalidade, eram alojados após 12 horas de vida, e $50,0 \%$ dos recém-nascidos de parto normal eram alojados a partir de três horas de vida.

Após a IHAC, de acordo com o segundo inquérito, todos os recém-nascidos de parto normal ou cirúrgico em boas condições de vitalidade, eram alojados imediatamente após o nascimento.

O alojamento conjunto é um sistema de internação utilizado para crianças que nascem em boas condições de vitalidade, caso contrário, as crianças são internadas em unidades de terapia intensiva. Como a população desta pesquisa são crianças internadas na UTI/UCI neonatal do HURNP, os profissionais foram questionados sobre o livre acesso da mãe a essas unidades, antes e após a IHAC.

A maioria respondeu que no início de 1995, antes da IHAC, não se permitia livre acesso da mãe a UTI/UCI neonatal, como se observa nos depoimentos abaixo:

Livre acesso não, era restrito ao horário de visitas (E6). 
...tinha acesso limitado pelas normas que determinavam que a mãe incomodava e atrapalhava a equipe e o serviço... (E7).

Todos admitiram que, após a IHAC, o acesso da mãe ao setor tornou-se mais flexivel, apesar da falta de infra-estrutura dessa unidade para acomodação das mães, conforme se observa nas seguintes falas:

A mãe fica o tempo que ela quiser. Quanto mais tempo ela puder ficar melhor, à noite, até às 22 horas, porque não temos acomodações adequadas (E6).

A mãe pode ficar o dia todo na UTI e também a noite inteira, normalmente, à noite, ela vai para casa descansar (E2).

\section{- Passo 8: Encorajar o Aleitamento sob livre Demanda}

O inquérito de 1995 mostrou que a maioria das mães (93,3\%) não havia recebido informações sobre a freqüência das mamadas; já o inquérito de 1998 revela que todas as mães afirmaram ter recebido orientação nesse sentido. Vale ressaltar que esses resultados referem-se também a mães de recém-nascidos em boas condições de vitalidade e que permaneceram em alojamento conjunto.

A aplicação deste passo em relação a crianças internadas em unidades de terapia intensiva é possível, dependendo das condições de saúde 
do recém-nascido e da presença da mãe na unidade. As respostas dos profissionais da UTI/UCI neonatal mostraram que, antes da implantação da IHAC, este passo não era aplicado no setor, como se pode observar através dos seguintes relatos:

Antes da IHAC parecia que isto não era importante pára as crianças da UTI (E1).

Este passo era aplicado para o bebê que ficava ao lado da mãe, para os da UTI não (E7).

Não se praticava porque a mãe não permanecia lá (E5).

Quando questionados se houve mudança relativa a esta conduta após a IHAC, a maioria dos entrevistados respondeu que sim, conforme revelam os seguintes depoimentos:

Com a vinda da IHAC passou a existir a preocupação de que a partir do momento que o bebê suga, como a mãe tem livre acesso a UTI, ela pode estar alimentando o seu filho (E2).

Com certeza houve, assim que o recém-nascido passa a ter condições de sugar a equipe orienta a mãe a amamentar por livre demanda, pois a mãe tem livre acesso à UTI (E6).

Hoje livre demanda fala-se também para crianças internadas $e$ nós mudamos de postura em relação a isto (E7). 


\section{- Passo 9: Não dar bicos Artificiais ou Chupetas a Crianças Amamentadas ao Selo}

$\mathrm{Na}$ época do primeiro inquérito, a avaliação deste passo ficou prejudicada porque estava ocorrendo, na UTI/UCI neonatal e na maternidade do HURNP, a substituição de bicos artificiais pelo "copinho" para oferecimento de leite aos bebês. Dentre as crianças amamentadas com leite artificial $(93,3 \%)$, algumas já o haviam recebido pelo "copinho". Com relação ao uso de chupeta, todas as mães afirmaram que seus filhos não a usavam. As crianças em fototerapia recebiam, rotineiramente, chás em mamadeiras. Após a IHAC, houve abolição desta prática, como demonstrou o segundo inquérito.

A maioria dos profissionais da UTI/UCI referiu que, apesar do desencadeamento do processo de retirada de bicos artificiais do setor de neonatologia, esta prática ainda era comum no início de 1995. Somente após a IHAC, os bicos artificiais foram abolidos e as chupetas usadas sob orientação médica, conforme revelam as falas a seguir:

Após a IHAC somente a chupeta é usada e com critério, como exemplo: um recém-nascido a termo com hipertensão pulmonar que precisa de oxigênio, qualquer esforço que ele faça cai a oximetria, portanto, dá-se o bico para que ele fique tranqüilo não exigindo assim maior quantidade de $\mathrm{O}_{2}$. Tudo isto é justificado no prontuário (E8). 
Veja, depois da IHAC somente o uso de chupeta e mesmo assim em casos especiais como nas fendas palatinas onde a fono orienta o bico até a criança começar a sucção. Em alguma debilidade de sucção também é indicado, mas quando isto acontece a gente documenta no prontuário (E2).

- Passo 10: encorajar a formação de Grupos de apolo ao am, Para Onde as Mães Deverão Ser Encaminhadas por Ocasião da Alta Hospitalar ou ambulatorial

O primeiro inquérito mostrou que o serviço de apoio ao AM mantido pelo HURNP era o BLH, porém, a rotina existente naquela época, não era clara quanto ao encaminhamento das mães a esse serviço no momento da alta hospitalar. Nenhuma mãe referiu encaminhamento a grupos comunitários de apoio ao AM; somente a Postos de Saúde e ambulatórios do próprio HURNP foram citados. O inquérito de 1998 constatou que todos os recém-nascidos, de acordo com a necessidade, são agendados previamente para os serviços de apoio ao AM do HURNP - Banco de Leite Humano, Clínica de Lactaçăo, Ambulatório de Puericultura e Ambulatório de Prematuridade, uma vez que não há, em Londrina, grupos de apoio ao AM organizados pela comunidade. Os relatos seguintes confirmam essa situação:

Não temos grupos de mães formalizados nem na instituição e nem na cidade. $O$ que temos para garantir o retorno destas mães $\dot{e}$ 
a reunião do AM na alta onde ela tira as dúvidas e recebe o cartão-criança com o agendamento específico para aquela criança. A gente tenta garantir o retorno com menos de 15 dias após a alta, para resolver dívidas relativas ao $A M(\mathrm{E} 2)$.

Encaminhamos à clínica de lactação. Se for criança da UTI, se é prematuro extremo continua sempre com o ambulatório de prematuro. Outras crianças vão para a puericultura e a criança normal é encaminhada ao Posto de Saúde (E8).

É feito encaminhamento para clinica de lactação para orientação e quanto ao retorno ao ambulatório para todos os nenezinhos que ficam internados (E3). 


\subsection{Evolução do Padrão Alimentar dos Pacientes INTERNADOS NA UTI/UCI NEONATAL DO HURNP}

\subsubsection{Estudo Preliminar da EVoluÇÃo do PadRão Alimentar DOS PACIENTES INTERnados DURANTE OS MESES de MÁRÇO E ABRIL, NO PERÍOdo dE 1994 A 1998}

Este estudo preliminar foi realizado para conhecer a evolução anual do padrão alimentar dos pacientes internados na UTI/UCI neonatal do HURNP, no período de 1994 a 1998. Para tanto, foram escolhidos os meses de março e abril de cada ano. A Tabela 1 mostra as mudanças no tipo de alimentação ao longo do período. 
4 Resultados

TABELA 1 - Distribuição percentual de recém-nascidos segundo o tipo de alimentação recebida durante internação na UTI/UCI neonatal do HURNP em Londrina, PR, 1994 a 1998*.

\begin{tabular}{|c|c|c|c|c|c|}
\hline \multirow{2}{*}{$\begin{array}{c}\text { REGIME ALIMENTAR } \\
\text { DURANTE A INTERNAÇÃo }\end{array}$} & 1994 & 1995 & 1996 & 1997 & 1998 \\
\hline & $n=45$ & $n=47$ & $n=54$ & $n=40$ & $n=64$ \\
\hline Leite Humano Exclusivo & 0,0 & 12,5 & 16,7 & 7,9 & 52,4 \\
\hline Só da Mãe & 0,0 & 5,0 & 11,1 & 5,3 & 17,5 \\
\hline Só do Banco & 0,0 & 7,5 & 3,7 & 2,6 & 4,8 \\
\hline Mãe + Banco & 0,0 & 0,0 & 1,9 & 0,0 & 30,2 \\
\hline FóRMULA EXCLUSIVA & 52,2 & 5,0 & 0,0 & 0,0 & 0,0 \\
\hline Leite Humano + Fórmula & 47,8 & 82,5 & 83,3 & 92,1 & 47,6 \\
\hline Mãe + Fórmula & 47,8 & 62,5 & 14,8 & 5,3 & 1,6 \\
\hline Banco + Fórmula & 0,0 & 0,0 & 1,8 & 0,0 & 0,0 \\
\hline Mãe + Banco + Fórmula & 0,0 & 20,0 & 66,7 & 86,8 & 46,0 \\
\hline TOTAL & 100,0 & 100,0 & 100,0 & 100,0 & 100,0 \\
\hline
\end{tabular}

*Inclui apenas recém-nascidos internados nos meses de março e abril.

Em 1994 havia predomínio da utilização de fórmula exclusiva $(52,2 \%)$ e a não utilização de leite humano exclusivo (0,0\%). A partir de 1995 , coincidindo com o início do processo de implantação da IHAC no HURNP, observa-se um aumento gradual da utilização de leite humano exclusivo, com exceção de 1997, que por razões desconhecidas, houve uma diminuição na 
oferta de leite humano exclusivo. Em 1998, praticamente com a IHAC implantada, houve uma inversão no regime alimentar das crianças internadas na UTI/UCI neonatal, ou seja, abolição total da fórmula exclusiva (de $52,2 \%$ para $0,0 \%$ ) e aumento significativo da utilização de leite humano exclusivo (de $0,0 \%$ para $52,4 \%$ ).

Observa-se ainda na Tabela 1 que há aumento do regime alimentar leite humano associado à fórmula nos anos de 1995 a 1997 e redução em 1998, porém, há diminuição da utilização de leite da própria mãe associado à fórmula (de $47,8 \%$ em 1994 para $1,6 \%$ em 1998) e, um aumento gradativo da utilização do leite da própria mãe associado ao leite do banco e à fórmula, sugerindo que passou-se a utilizar maior quantidade do leite da própria mãe e do banco de leite em substituição à fórmula, ao longo do período de 1994 a 1998. A constatação desta mudança levou a pesquisadora a definir como amostra final para o estudo todos os prontuários dos pacientes internados na UTI/UCI neonatal do HURNP durante os anos de 1994 e 1998.

\subsubsection{Evolução do Padrão Alimentar dos Pacientes INTERNADOS NA UTI/UCI NEONATAL DO HURNP DURANTE OS ANOS DE 1994 E 1998}

A Tabela 2 sumariza os dados referentes às caracteristicas dos recém-nascidos internados na UTI/UCI neonatal em 1994 e 1998. 
TABELA 2 - Características dos recém-nascidos internados na UTI/UCI neonatal do HURNP em Londrina, PR, 1994 e 1998.

\begin{tabular}{|c|c|c|c|c|c|}
\hline \multirow{2}{*}{ VARIÁVEIS } & \multicolumn{4}{|c|}{$1994(n=268) * 1998(n=350) *$} & \multirow{2}{*}{$\begin{array}{l}\text { VALOR } \\
\text { DE p }\end{array}$} \\
\hline & $\mathbf{n}$ & $(\%)$ & $\mathbf{n}$ & $(\%)$ & \\
\hline \multicolumn{6}{|c|}{ PROCEDÊNCIA (MATERNA) } \\
\hline Londrina & 207 & 77,2 & 224 & 64,0 & \multirow[t]{2}{*}{$<0,01$} \\
\hline Região & 61 & 22,8 & 126 & 36,0 & \\
\hline \multicolumn{5}{|l|}{ SEXO } & \multirow{3}{*}{ NS } \\
\hline Masculino & 117 & 43,3 & 173 & 49,6 & \\
\hline Feminino & 151 & 56,3 & 176 & 50,4 & \\
\hline \multicolumn{5}{|c|}{ PESO AO NASCER (gramas) } & \multirow{4}{*}{$<0,05$} \\
\hline$<1500$ & 51 & 19,0 & 59 & 16,9 & \\
\hline 1500 a 2499 & 136 & 50,7 & 148 & 42,3 & \\
\hline 2500 ou mais & 81 & 30,2 & 143 & 40,9 & \\
\hline \multicolumn{5}{|c|}{$\begin{array}{c}\text { CLASSIFICAÇÃO DA } \\
\text { MATURIDADE (SEMANAS) }\end{array}$} & \multirow{4}{*}{ NS } \\
\hline Pré-Termo $(<37)$ & 173 & 66,8 & 217 & 63,5 & \\
\hline A Termo $(37-42)$ & 83 & 32,0 & 122 & 35,7 & \\
\hline Pós-Termo (> 42) & 3 & 1,2 & 3 & 0,9 & \\
\hline \multicolumn{5}{|c|}{ RELAÇÃo PESO/IDADE GESTACIONAL } & \multirow{4}{*}{$<0,001$} \\
\hline$P \mid G$ & 62 & 23,1 & 49 & 14,0 & \\
\hline$A \mid G$ & 201 & 75,0 & 269 & 76,9 & \\
\hline GIG & 5 & 1,9 & 32 & 9,1 & \\
\hline \multicolumn{5}{|c|}{ DURAÇÃO DA INTERNAÇÃO (DIAS) } & \multirow{9}{*}{ NS } \\
\hline 1 a 5 & 60 & 22,4 & 87 & 24,9 & \\
\hline 6 a 10 & 70 & 26,1 & 96 & 27,4 & \\
\hline 11 a 15 & 34 & 12,7 & 33 & 9,4 & \\
\hline 16 a 20 & 24 & 9,0 & 23 & 6,6 & \\
\hline 21 a 25 & 19 & 7,1 & 24 & 6,9 & \\
\hline 26 a 30 & 15 & 5,6 & 11 & 3,1 & \\
\hline 31 a 35 & 9 & 3,4 & 19 & 5,4 & \\
\hline 36 ou mais & 37 & 13,8 & 57 & 16,3 & \\
\hline \multicolumn{5}{|l|}{$\begin{array}{c}\text { ÍNDICE DE APGAR } \\
\underline{1^{\circ} \text { MINUTO }}\end{array}$} & \multirow{8}{*}{0,01} \\
\hline 0 a 3 & 52 & 19,8 & 38 & 11,4 & \\
\hline 4 a 7 & 77 & 29,4 & 81 & 24,3 & \\
\hline 8 a 10 & 133 & 50,8 & 215 & 64,4 & \\
\hline$\underline{5^{\circ} \text { Minuto }}$ & & & & & \\
\hline 0 a 3 & 9 & 3,4 & 4 & 1,2 & \\
\hline 4 a 7 & 41 & 15,6 & 31 & 9,3 & \\
\hline 8 a 10 & 212 & 80,9 & 298 & 89,5 & \\
\hline
\end{tabular}

*Excluídos todos os óbitos até 48 horas. NS = Não significativo. 
Verifica-se que, neste período, há aumento da freqüência de recém-nascidos de mães que residiam fora de Londrina, diminuição dos recém-nascidos de baixo peso e pequenos para a idade gestacional e melhora na distribuição do índice de Apgar. As distribuições de sexo, idade gestacional e duração da internação não se alteraram no período.

A Tabela 3 descreve o tipo de alimentação recebida pelos recém-nascidos internados na UTI/UCI neonatal do HURNP, em 1994 e 1998.

TABela 3 - Distribuição percentual de recém-nascidos, segundo o tipo de alimentação recebida durante internação na UTI/UCI neonatal do HURNP em Londrina, PR, 1994 e 1998.

\begin{tabular}{|c|c|c|}
\hline \multirow{2}{*}{$\begin{array}{l}\text { REgIME ALIMENTAR DURANTE A } \\
\text { INTERNAÇÃo }\end{array}$} & 1994 & 1998 \\
\hline & $(\mathrm{n}=257) *$ & $(n=345) *$ \\
\hline Leite Humano Exclusivo & 1,9 & 41,7 \\
\hline Só da Mãe & 1,9 & 9,6 \\
\hline Só do Banco de Leite & 0,0 & 1,4 \\
\hline Mãe + Banco de Leite & 0,0 & 30,7 \\
\hline FóRMULA EXCLUSIVA & 17,9 & 0,0 \\
\hline LeITE HuMANo + Fórmula & 80,2 & 58,3 \\
\hline Mãe + Fórmula & 80,2 & 0,6 \\
\hline Banco + Fórmula & 0,0 & 1,2 \\
\hline Mãe + Banco + Fórmula & 0,0 & 56,3 \\
\hline TOTAL & 100,0 & 100,0 \\
\hline
\end{tabular}

$\mathrm{p}<0,0001$

*Excluídos os óbitos até 48 horas e ainda 11 casos (4,1\%) em 1994 e 5 casos $(1,4 \%)$ em 1998, por falta de anotação nos prontuários. 
Mudanças significativas no regime alimentar dos recém-nascidos são observadas no periodo $(p<0,0001)$, destacando-se um aumento expressivo do percentual de crianças que passaram a receber exclusivamente leite humano (1,9\% em 1994 para 41,7\% em 1998). Observa-se ainda que, em 1994 , não se utilizava leite humano do banco apesar da existência do BLH no hospital; em 1998, o BLH passa a ter participação ativa na manutenção do AME das crianças internadas na UTI/UCI neonatal, ocorrendo o abandono da prática da utilização da fórmula exclusiva.

No que se refere à utilização de combinações de tipos de leite nota-se que, em $1994,80,2 \%$ das crianças recebiam leite da própria mãe associado à fórmula; em 1998, a associação leite da própria mãe e fórmula virtualmente desaparece $(0,6 \%)$, sendo substituída, em grande medida, pela combinação de leite da própria mãe, leite do banco e fórmula. Vale ressaltar que, através da análise dos prontuários das crianças de 1998, quando se oferecia à criança leite da própria mãe + banco + fórmula, constatou-se que pelo menos $2 / 3$ do volume desta associação era composto por leite da própria mãe e o restante de leite do BLH e fórmula, mostrando uma maior participação da mãe e do banco de leite e menor utilização de fórmulas.

Como se observou anteriormente, os recém-nascidos estudados em 1994 diferiram significativamente dos recém-nascidos estudados em 1998 em relação a cinco variáveis: procedência materna, peso ao nascer, relação peso/idade gestacional e Índice de Apgar, tanto no $1^{\circ}$ como no $5^{\circ}$ minuto. 
Objetivando controlar a influência que essas variáveis poderiam ter nas modificações observadas quanto ao regime alimentar dos recém-nascidos, aplicou-se um modelo de regressão logística ao conjunto das observações de 1994 e 1998. Nesse modelo, o regime alimentar foi a variável dependente; o ano de internação a variável independente e as cinco variáveis mencionadas acima foram consideradas de controle. No modelo de regressão, o regime alimentar foi categorizado AME e Não $\mathrm{AME}$, devido ao desaparecimento de casos que recebiam fórmula exclusiva em 1998. Os resultados relativos à regressão logística são apontados na Tabela 4.

TABELA 4 - Distribuição de recém-nascidos, segundo regime alimentar e Odds Ratio para AME durante internação na UTI/UCI neonatal do HURNP em Londrina, PR, 1994 e 1998.

\begin{tabular}{|c|c|c|c|c|}
\hline \multirow{2}{*}{$A N O$} & \multicolumn{2}{|c|}{$\begin{array}{c}\text { REGIME ALIMENTAR } \\
\text { DURANTE A INTERNAÇÃo }\end{array}$} & \multicolumn{2}{|c|}{$\begin{array}{l}\text { ODDS RATIO } \\
\text { ( IC } 95 \% \text { ) }\end{array}$} \\
\hline & A ME & NÃO A ME & BRUTO & AJUSTADO* \\
\hline 1994 & 5 & 252 & 1,0 & 1,0 \\
\hline 1998 & 144 & 201 & $\begin{array}{c}36,1 \\
(13,9-101,8)\end{array}$ & $\begin{array}{c}35,7 \\
(14,2-89,9)\end{array}$ \\
\hline
\end{tabular}

$p<0,0001$

* Ajustado para o peso ao nascer, relação peso/idade gestacional e índice de Apgar no $1^{\circ}$ minuto.

No modelo final da análise de regressão logística, mantiveram-se significativamente associados à freqüência do AME o ano de internação e as 
4 Resultados

seguintes variáveis de controle: peso ao nascer, relação peso/idade gestacional e índice de Apgar no $1^{\circ}$ minuto. $O$ controle das variáveis de confusão atenuou apenas ligeiramente a forte associação entre o ano de internação e o AME: Odds Ratio bruto de 36,1 antes do controle e Odds Ratio de 35,7 após o controle.

\subsection{Frequência do Aleitamento Materno nos Primeiros Seis Meses de Vida em Pacientes INTERnados na UTI/UCI NEONATAL DO HURNP EM 1994 E 1998}

Em ambos os anos, houveram perdas de informação sobre o tipo de aleitamento materno recebido pelas crianças nos primeiros seis meses de vida. A ausência desta informação decorreu da criança não ter retornado ao ambulatório de acompanhamento do HURNP e à falta de anotação, no prontuário, sobre o tipo de aleitamento que a criança estava recebendo no momento do retorno. O percentual de perdas foi semelhante nos dois anos, correspondendo a 33,4\% das crianças internadas em 1994 e a $34,8 \%$ em 1998 $(p=0,85)$. Observou-se também que as características das crianças sem informaçס̃es sobre o tipo de aleitamento recebido nos primeiros seis meses de vida não se alteraram significativamente entre 1994 e 1998 (Tabela 5). 
4 Resultados

TABELA 5 - Características dos recém-nascidos internados na UTI/UCI neonatal do HURNP com ausência de informação sobre o regime alimentar após alta hospitalar. Londrina, PR, 1994 e 1998.

\begin{tabular}{|c|c|c|c|}
\hline \multirow{2}{*}{ VARIÁVEIS } & \multicolumn{2}{|c|}{ A N 0} & \multirow{2}{*}{$\begin{array}{l}\text { VALOR DE p DE } \\
\text { MANTAEL-HAENSZEL }\end{array}$} \\
\hline & $\begin{array}{c}1994 \\
(\%)\end{array}$ & $\begin{array}{c}1998 \\
(\%)\end{array}$ & \\
\hline \multicolumn{4}{|l|}{ PROCEDÊnCIA (MATERNA) } \\
\hline Londrina & 30,2 & 27,9 & \multirow[t]{2}{*}{0,503} \\
\hline Região & 19,3 & 35,9 & \\
\hline \multicolumn{4}{|l|}{ PESO AO NASCER (gramas) } \\
\hline$<1500$ & 24,3 & 8,9 & \multirow{3}{*}{0,896} \\
\hline 1500 a 2499 & 20,2 & 23,1 & \\
\hline 2500 e mais & 41,3 & 45,7 & \\
\hline \multicolumn{4}{|l|}{$\begin{array}{l}\text { RELAÇÃo PESO/IDADE } \\
\text { GESTACIONAL }\end{array}$} \\
\hline$P \mid G$ & 22,2 & 26,1 & \multirow{2}{*}{0,564} \\
\hline Não P | G & 29,2 & 31,5 & \\
\hline \multicolumn{4}{|l|}{$\begin{array}{c}\text { ÍNDice DE APGAR } \\
1^{\circ} \text { Minuto }\end{array}$} \\
\hline 0 a 3 & 25,0 & $0,0 *$ & \multirow[t]{3}{*}{0,615} \\
\hline 4 a 7 & 34,4 & 23,1 & \\
\hline 8 a 10 & 27,0 & 31,3 & \\
\hline \multicolumn{4}{|l|}{$\begin{array}{c}\text { REGIME ALIMENTAR DURANTE A } \\
\text { INTERNAÇÃo }\end{array}$} \\
\hline AME & 33,3 & 47,4 & 0,112 \\
\hline Não AME & 27,0 & 19,5 & \\
\hline
\end{tabular}

* Teste de Fisher. 
A Tabela 6 volta a comparar as crianças internadas na UTI/UCI neonatal do HURNP em 1994 e 1998, restringindo-se dessa vez àquelas com informações sobre a frequência do aleitamento materno durante os primeiros seis meses de vida. Verifica-se diminuição dos recém-nascidos pequenos para a idade gestacional e aumento dos adequados e grandes para a idade gestacional. Com relação à duração da internação, há um discreto aumento do número de internações entre 1 a 5 dias e também de 36 dias ou mais. A distribuição da procedência materna, sexo, peso ao nascer, classificação de maturidade e índice de Apgar não se alteraram no periodo. 
TABELA 6 - Características dos recém-nascidos internados na UTI/UCI neonatal do HURNP, acompanhados ao longo dos primeiros seis meses de vida. Londrina, PR, 1994 e 1998.

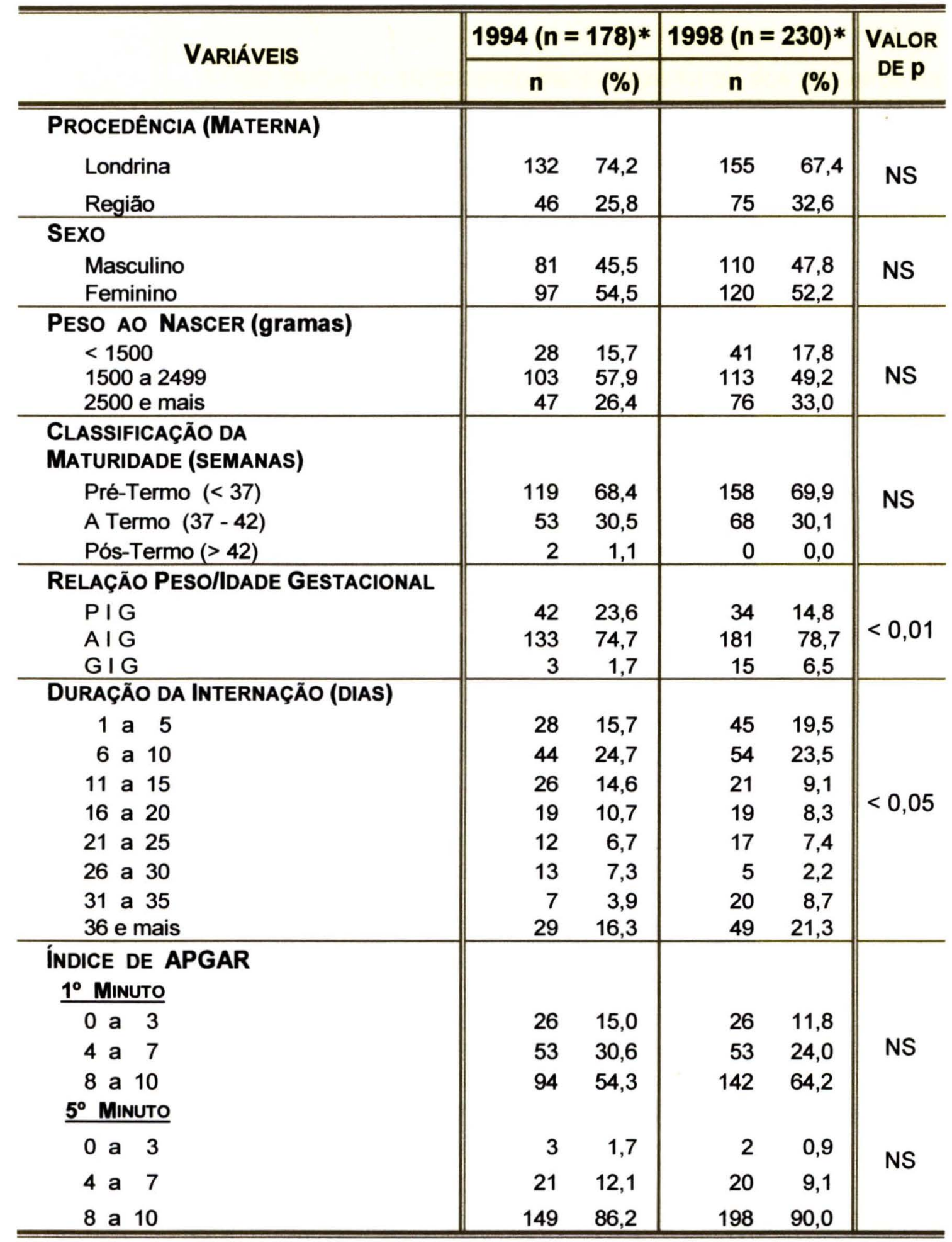

NS = Não significativo.

* Excluídos os óbitos até 48 horas e aqueles que não continham informação sobre o regime alimentar após alta hospitalar. 
A seguir serão apresentados os resultados referentes à freqüência do $A M$ e $A M E$ durante os primeiros seis meses de vida.

A freqüência do aleitamento materno ao longo dos primeiros seis meses de vida das crianças de 1994 e 1998 foi estimada através do emprego da técnica de sobrevida de Kaplan-Meier, distinguindo-se duas categorias: o AM e 0 AME.

A Figura 1 mostra o comportamento das curvas de sobrevida do AM durante os primeiros seis meses de vida.

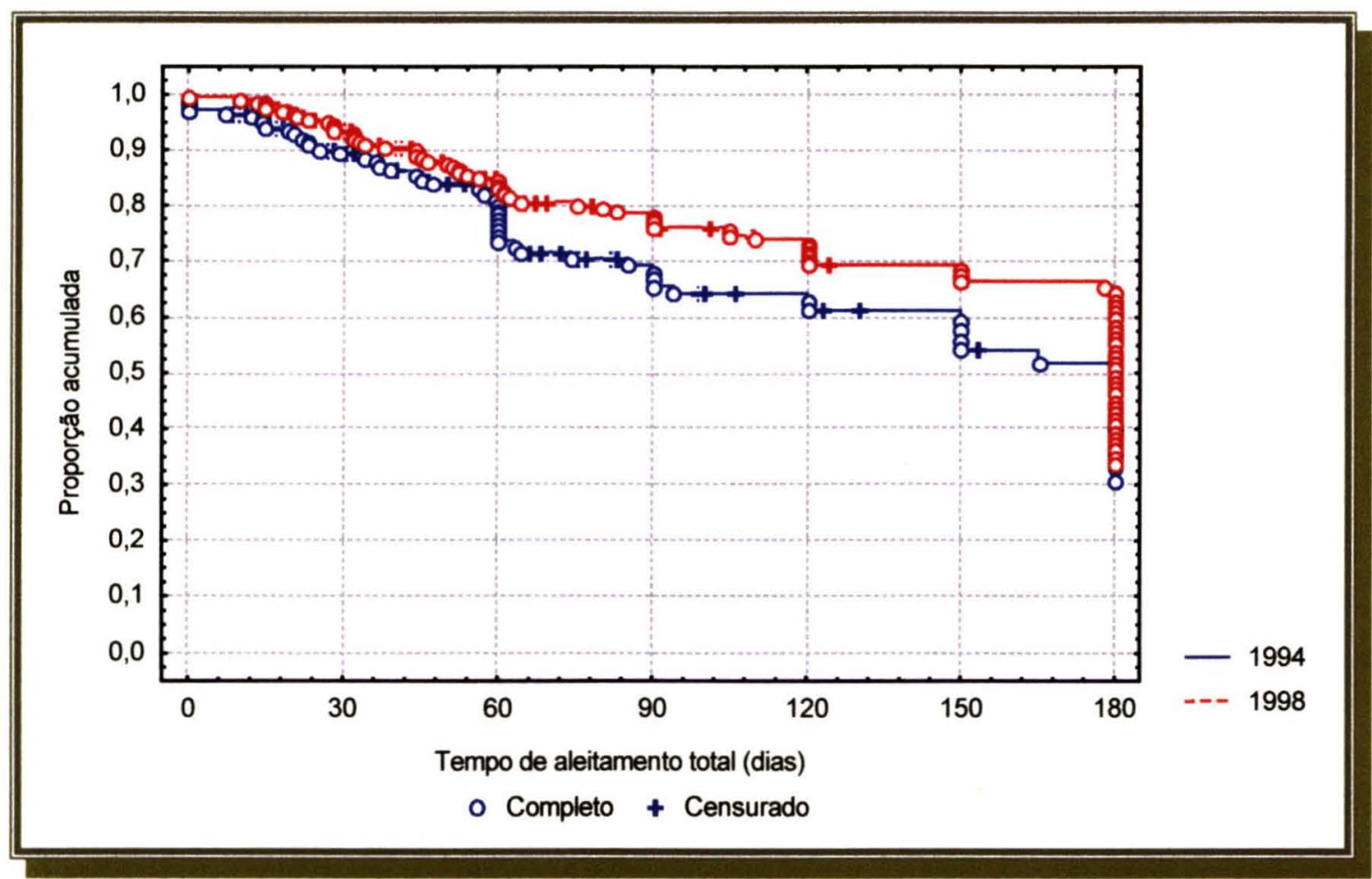

Figura 1 - Curvas de sobrevida do AM durante os primeiros seis meses de vida. Crianças internadas na UTI/UCI neonatal do HURNP em Londrina, PR, 1994 e 1998. 
Ao final do segundo mês de vida, em $1994,73,6 \%$ das crianças permaneciam em AM contra $83,1 \%$ em 1998 . Ao término do quarto mês, $61,2 \%$ das crianças de 1994 continuavam em AM contra 69,2\% em 1998. Ao completarem seis meses de vida, $31,0 \%$ das crianças em 1994 estavam em AM e, em $1998,34,0 \%$. O tempo mediano do AM foi de 176 dias para 1994 e de 180 dias para 1998 (Figura 1). O teste de Log-Rank não apontou diferença significativa entre as curvas de sobrevida do AM em 1994 e 1998.

A Figura 2 apresenta as curvas de sobrevida do AME durante os primeiros seis meses de vida.

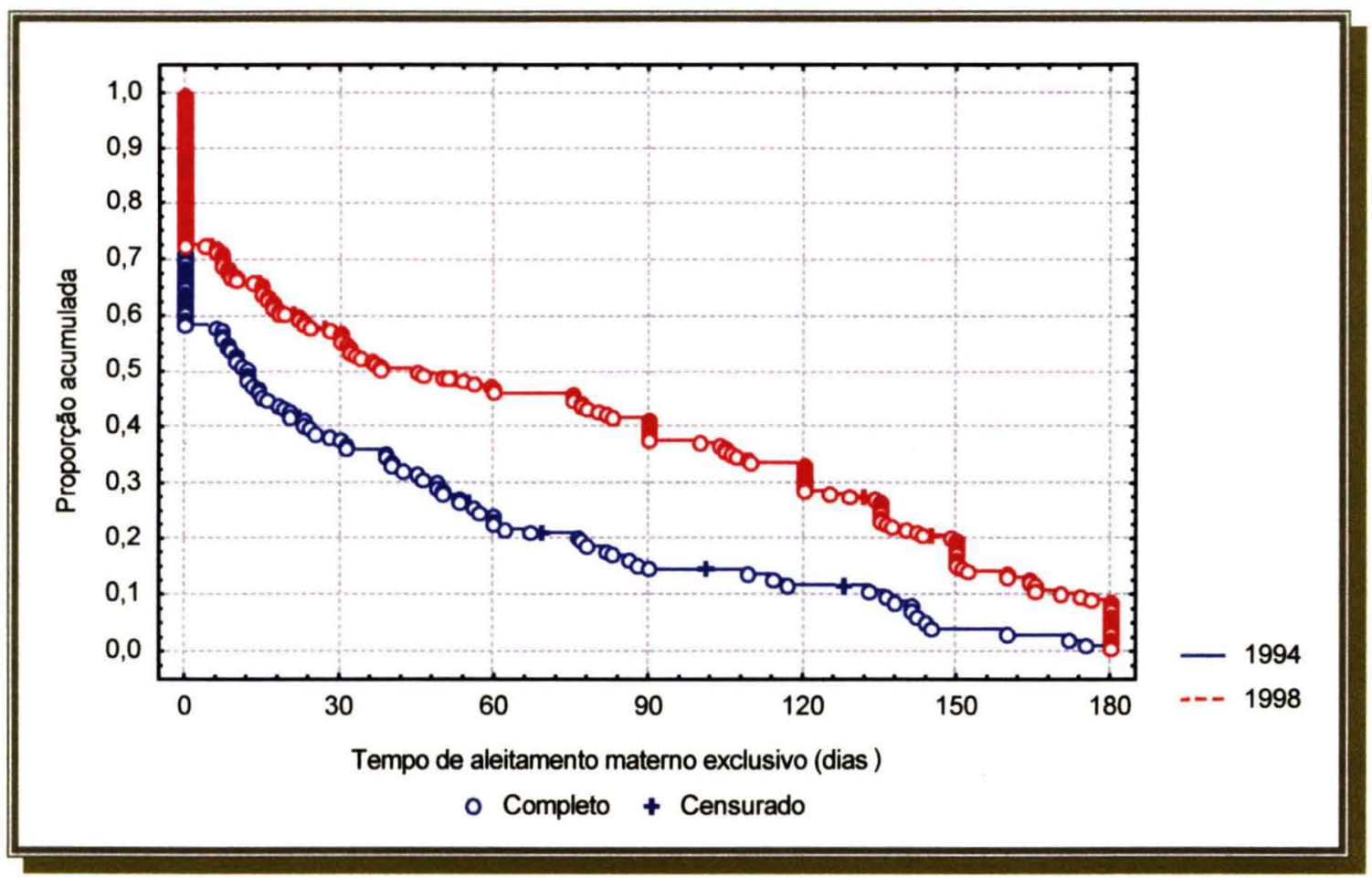

Figura 2 - Curvas de sobrevida do AME durante os primeiros seis meses de vida. Crianças internadas na UTI/UCI neonatal do HURNP em Londrina, PR, 1994 e 1998. 
Com relação ao AME, nota-se que os recém-nascidos de 1998, desde o nascimento, apresentam-se em situação mais vantajosa que os recém-nascidos de 1994, sendo que essa vantagem se mantém ou mesmo se amplia, até o sexto mês de vida (Figura 2). Ao final do segundo mês de vida, apenas $22,6 \%$ das crianças do grupo de 1994 estavam em AME contra $46,1 \%$ do grupo de 1998; ao final do quarto mês, somente $11,7 \%$ das crianças de 1994 continuavam com esse tipo de alimentação, aumentando para 28,6\% em 1998. Com cinco meses de vida, apenas $4,0 \%$ das crianças de 1994 encontravam-se em AME, enquanto que, em 1998, 15,2\% recebiam exclusivamente leite materno. O tempo mediano de AME foi de 12 dias para o grupo de crianças de 1994, aumentando para 45 dias em 1998. O teste de Log-Rank apontou diferença significativa $(p<0,001)$ entre as curvas de sobrevida do $A M E$, entre 0 grupo de crianças de 1994 e de 1998.

Como se viu anteriormente, as crianças de 1994 e de 1998, acompanhadas durante os primeiros seis meses de vida, diferiram significativamente $(p<0,05)$ em relação a duas variáveis: relação peso/idade gestacional e tempo de internação. Quanto às variáveis procedẻncia materna e Índice de Apgar no $1^{\circ}$ e $5^{\circ}$ minuto, não chegaram a alcançar significado estatístico $(0,05<p<0,20)$. Para controlar a influência que essas variáveis poderiam ter sobre a freqüência do $A M$ e do $A M E$ nos primeiros seis meses de vida, aplicou-se o modelo de regressão de Cox ao conjunto de crianças de 1994 e 1998. Os resultados relativos à regressão de Cox confirmaram a ausência de diferenças estatisticamente significativas quanto à freqüência do $A M$ nos 
primeiros seis meses de vida em 1994 e 1998 (para o AM em 1998 obteve-se OR ajustado $=1,07 ;$ IC $95 \% \quad 0,82-1,40)$.

Os resultados relativos à regressão de Cox para o AME nos primeiros seis meses de vida, são apresentados na Tabela 7. 
TABELA 7 - Análise do tempo de AME através da regressão de Cox univariada e multivariada: Qui-quadrado de Wald, valor de p, Odds Ratio e Intervalo de Confiança de 95\% em recém-nascidos internados na UTI/UCI neonatal do HURNP, acompanhados nos primeiros seis meses de vida. Londrina, PR, 1994 e 1998.

\begin{tabular}{|c|c|c|c|c|c|c|c|c|c|c|c|}
\hline \multirow{3}{*}{ VARIÁVEL } & \multirow{3}{*}{ CATEgorias } & \multicolumn{5}{|c|}{ UNIVARIADA (BRUTO) } & \multicolumn{5}{|c|}{ MULTIVARIADA (AJUSTADO) } \\
\hline & & \multirow{2}{*}{$\begin{array}{l}\chi^{2} \text { DE } \\
\text { WALD }_{\text {AL }}\end{array}$} & \multirow{2}{*}{$\begin{array}{l}\text { VALOR } \\
\text { DE } \rho\end{array}$} & \multirow{2}{*}{ O R } & \multicolumn{2}{|c|}{ I C $95 \%$} & \multirow{2}{*}{$\begin{array}{l}\chi^{2} \mathrm{DE} \\
\text { WALD }\end{array}$} & \multirow{2}{*}{$\begin{array}{l}\text { VALOR } \\
\text { DE } \rho\end{array}$} & \multirow{2}{*}{ O R } & \multicolumn{2}{|c|}{ I C $95 \%$} \\
\hline & & & & & Min. & MÁx. & & & & Mín. & MAX. \\
\hline Ano & $\begin{array}{l}1=1994 \\
2=1998\end{array}$ & 5,66 & 0,017 & 4,18 & 1,29 & 13,58 & 4,82 & 0,028 & 3,77 & 1,15 & 12,35 \\
\hline Procedência & $\begin{array}{l}1=\text { REGIÃO } \\
2=\text { LONDRINA }\end{array}$ & 0,64 & 0,423 & 0,78 & 0,43 & 1,42 & 0,96 & 0,327 & 0,72 & 0,38 & 1,38 \\
\hline Peso/IG & $\begin{array}{l}1=\text { PEQUENo } \\
2=\text { ADEQ+GRANDE }\end{array}$ & 0,49 & 0,482 & 1,39 & 0,55 & 3,49 & 0,02 & 0,894 & 1,06 & 0,42 & 2,68 \\
\hline $\begin{array}{l}\text { APGAR NO } 1^{\circ} \\
\text { MINUTO }\end{array}$ & $\begin{array}{l}1 \text { = ATÉ } 7 \\
2=8 \text { OU + }\end{array}$ & 2,57 & 0,109 & 0,62 & 0,35 & 1,11 & 4,56 & 0,033 & 0,47 & 0,24 & 0,94 \\
\hline $\begin{array}{l}\text { APGAR NO } 5^{\circ} \\
\text { MINUTO }\end{array}$ & $\begin{array}{l}1 \text { = ATÉ } 7 \\
2=8 \mathrm{OU}+\end{array}$ & 0,07 & 0,789 & 0,87 & 0,31 & 2,42 & 0,00 & 0,962 & 1,03 & 0,32 & 3,25 \\
\hline $\begin{array}{l}\text { TEMPO DE } \\
\text { INTERNAÇÃO }\end{array}$ & $\begin{array}{l}1=\text { ATÉ } 10 \text { DIAS } \\
2=11 \text { OU + DIAS }\end{array}$ & 4,20 & 0,040 & 0,53 & 0,29 & 0,97 & 6,62 & 0,010 & 0,41 & 0,21 & 0,80 \\
\hline
\end{tabular}


No modelo final da análise da regressão de Cox, mesmo após o controle das variáveis de confusão, persistiu significativa a maior freqüência do AME em 1998 (OR ajustado $=3,77$ : IC $95 \%$ de $1,15-12,35$ ), o que indica que ter nascido em 1994, portanto, antes da implantação da IHAC confere risco de 3,77 para a interrupção do AME. Do mesmo modo que, permanecer internados por menos de onze dias, confere proteção significativa para o AME (OR ajustado $=0,41$ : IC $95 \%$ de $0,21-0,80$ ). 


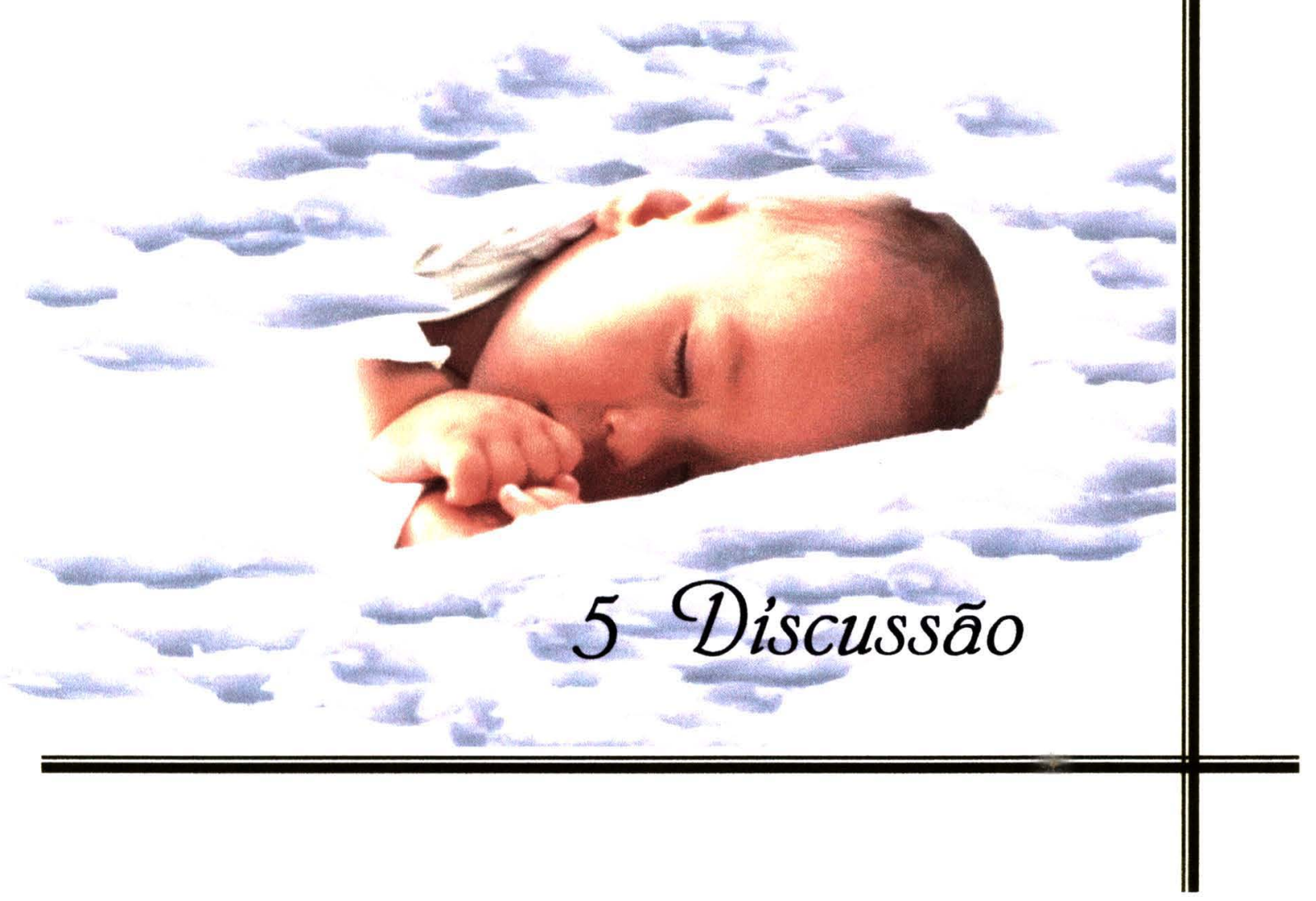




\subsection{Considerações Metodológicas}

De acordo com a OMS, efetividade é a expressão do efeito desejado de um programa, serviço, instituição ou atividade de apoio em reduzir um problema de saúde ou melhorar uma situação de saúde insatisfatória. Mede - grau em que se atingem os objetivos e metas predeterminados de um programa, serviço ou instituição (OMS 1991).

O propósito desta pesquisa foi avaliar os resultados advindos da implantação da IHAC na UTI/UCI neonatal do HURNP relativos ao aleitamento materno, através de um estudo do tipo "Antes" e "Depois" (RATTNER 1991). A Figura 3 apresenta a seqüência utilizada para realização das avaliações da IHAC no HURNP.

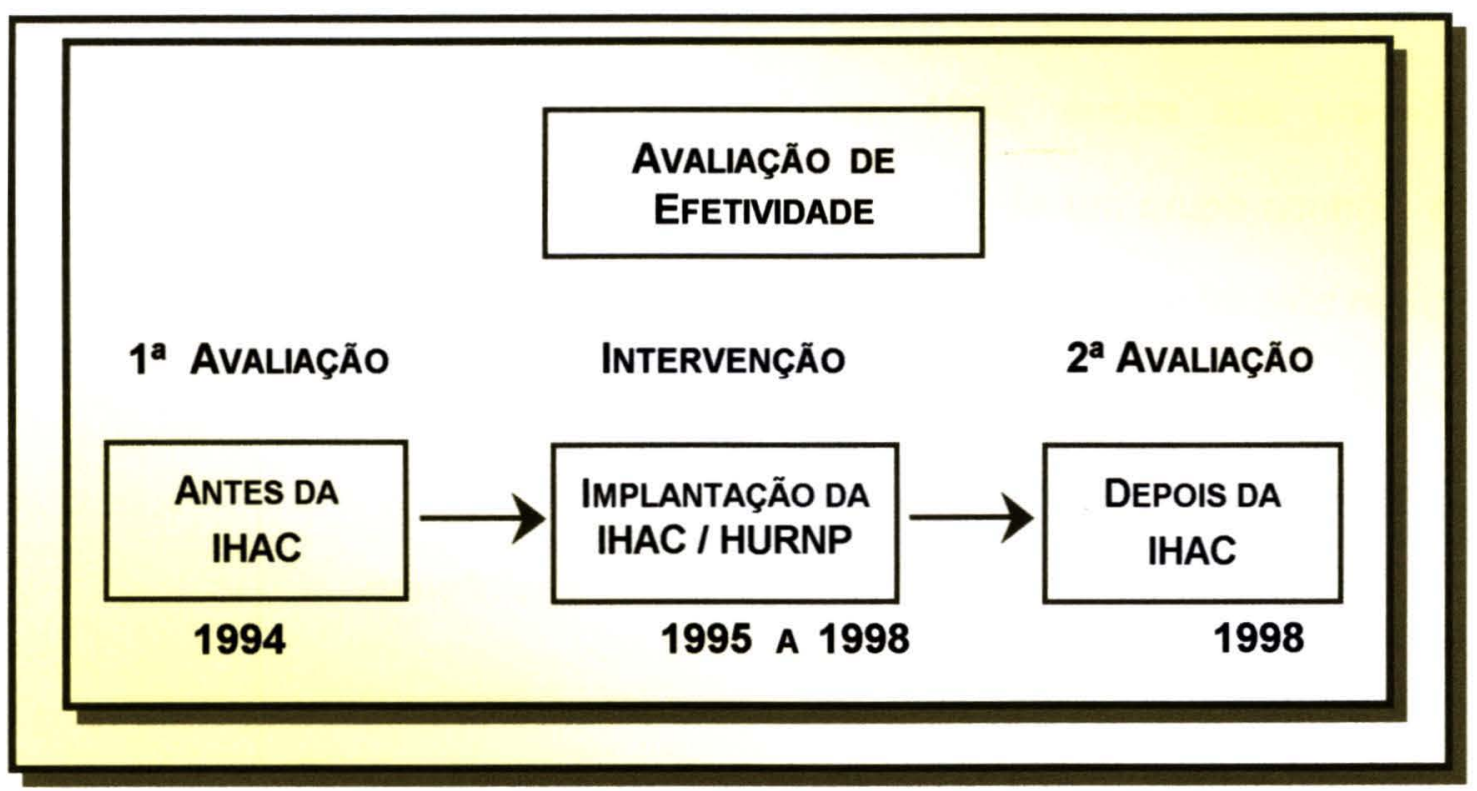

FiguRA 3 - Seqüência do processo de Avaliação da IHAC no HURNP. 
As avaliações do tipo "Antes" e "Depois" têm, sobretudo, relevância para o desenho dos programas, pois permitem visualizar os resultados e benefícios que foram produzidos como conseqüência da ação dos mesmos (GIL 1995).

No Brasil são comuns as avaliações de efetividadé em intervenções já implantadas pelos serviços (NOVAES 2000). Se, por um lado, isto é desejável uma vez que a avaliação deve ser incorporada à prática dos serviços, por outro lado, pode gerar limitações de ordem metodológica para a realização de pesquisas. Nessa perspectiva, o presente estudo, por ter sido realizado após a implantação da IHAC e desenvolvido através de análises das normas e rotinas do serviço, apresenta as seguintes limitações:

1. Não houve sorteio de um grupo controle. Ele corresponde à população de recém-nascidos internados na UTI/UCI neonatal do HURNP em 1994, época que precede a implantação da IHAC. O sorteio de um grupo controle seria inviável não somente pelo fato da pesquisa ter sido realizada após a implantação da IHAC no HURNP, como também por questões éticas, uma vez que teríamos um grupo que se beneficiaria do aleitamento materno e outro não.

2. O método de avaliação do tipo "Antes" e "Depois" sugere que a medida da variável de interesse na pesquisa seja feita 
pouco antes e logo após a intervenção, o que não foi possível nesta pesquisa por termos obedecido à dinâmica do serviço. Assim, a medida das variáveis de interesse "Depois", só ocorreu em 1998 época em que se concretizou a implantação da IHAC no HURNP. Neste periodo de quase quatro anos pode ter possibilitado que as mães da população "Depois" da implantação da IHAC, tenham recebido, de outras fontes, mais informações sobre aleitamento materno do que as mães de 1994 ("Antes"). Para atenuar esta limitação, tomamos como base o resultado do estudo preliminar realizado durante dois meses de cada um dos anos do período de 1994 a 1998, o qual mostrou evolução gradativa do regime alimentar dos recém-nascidos internados na UTI/UCI neonatal, evoluindo de fórmula para leite humano.

3. É possível que o grupo de crianças de 1994 não seja igual ao de 1998 com relação a outras variáveis que não as controladas na análise multivariada, que influenciem na freqüência da amamentação. Com relação a essa limitação, como se trata de recém-nascidos de risco internados em UTI/UCI neonatal, o peso ao nascer e a idade gestacional são duas variáveis importantes a serem consideradas na 
amamentação dessas crianças, portanto, ambas foram controladas nos testes estatisticos realizados.

4. No período de realização das entrevistas coin os profissionais de saúde, a IHAC era foco de ampla discussão no HURNP, o que pode ter influenciado as respostas dos entrevistados. Podem também ter ocorrido limitações de lembrança dos profissionais quando questionados sobre a época anterior à implantação da IHAC no HURNP, uma vez que haviam passado quase seis anos. Esta limitação está relacionada com a implantação da IHAC no HURNP e não propriamente ao sucesso da amamentação. Neste sentido, os resultados relativos ao aleitamento materno, após a implantação da IHAC na UTI/UCI neonatal do HURNP, foram suficientemente significativos para serem creditados a vieses metodológicos. Por outro lado, há estudos em populaçб̃es controladas que mostram a efetividade da IHAC sobre o AME.

LUTHER et al. (1997) compararam, em Santos-SP, dois grupos de mulheres, sendo que um deu a luz num hospital "Amigo da Criança" e outro grupo de mulheres, que deu a luz num hospital que não possuía o programa (grupo controle). Os resultados mostraram um aumento de 53 dias para o 
AME entre as mulheres que deram a luz no hospital "Amigo da Criança".

CORREA (1996) analisou o impacto das ações de saúde na duração do aleitamento materno total em crianças nascidas em dois hospitais de Santos-SP, sendo um deles "Amigo da Criança". Os resultados mostraram que a implantação dos "Dez Passos" direcionam as necessidades de proteção, promoçăo e incentivo ao aleitamento materno nas maternidades.

\subsection{O Impacto da InICIATIVA Hospital Amigo dA Criança no aleitamento materno na Uti/UCI NEONATAL DO HURNP}

Considerando que uma das principais causas do insucesso da amamentação é atribuída às práticas hospitalares, a IHAC tem como objetivo, entre outros, mobilizar os profissionais de saúde para mudarem práticas e rotinas que possam levar ao desmame precoce.

Embora a IHAC tenha se disseminado rapidamente por todo o mundo, poucos são os relatos existentes na literatura a respeito do seu impacto sobre as taxas de aleitamento materno e são particularmente raras as publicações que tratam do papel da IHAC para crianças prematuras e de baixo 
peso, enfim, aquelas que necessitam de internação em unidades de terapia intensiva logo após o nascimento.

Estudo realizado por TOMA (1998) sobre diagnóstico do cumprimento dos "Dez Passos" em maternidades públicas e privadas do município de São Paulo, revelou que a maioria dos hospitais com alojámento conjunto adota um peso mínimo ao nascer necessário para que o recém-nascido permaneça junto à sua mãe. Os pesos minimos de $2000 \mathrm{~g}$ e de $2500 \mathrm{~g}$ estabelecidos, respectivamente por $50 \%$ e $33,3 \%$ dos hospitais fazem com que os benefícios do aleitamento materno se restrinjam a uma pequena parcela de recém-nascidos de baixo peso. Além disso, o mesmo estudo indicou que cerca de $50 \%$ dos hospitais do município de São Paulo não permitem que a mãe de um recém-nascido prematuro entre livremente na unidade de internação e cerca de $40 \%$ não orientam adequadamente a mãe sobre medidas para manter a lactação, mesmo separada do filho. Apenas $18,4 \%$ dos hospitais utilizam leite materno pasteurizado, o que torna mais difícil manter a lactação das mães dos prematuros.

Segundo LEVIN (1999), a IHAC está direcionada para a amamentação de crianças saudáveis, o que deveria ser repensado, uma vez que, em diferentes países, 5 a $7 \%$ das crianças nascem com problemas de saúde e, para elas, a amamentação é mais importante ou, no mínimo, tão importante quanto para as crianças sadias. Por outro lado, existe a interferência das indústrias de leite artificial que apoiam pesquisas com o intuito de mostrar 
que, para as crianças com problemas de saúde, as fórmulas são melhores que o leite materno. Este fato tem gerado, nas unidades neonatais, violação do código internacional que regulamenta a utilização de produtos substitutos do leite materno.

Entre os "Dez Passos" da IHAC, os Passos 5, 6 e 9,estão relacionados ao aleitamento materno de recém-nascidos prematuros e de baixo peso, porém não há detalhamento dos aspectos importantes e inerentes a esse grupo. Considerando que a população desta pesquisa refere-se a recém-nascidos de risco internados logo após o nascimento, a discussão sobre o impacto de cada um dos "Dez Passos" no aleitamento materno dessas crianças focalizará inicialmente estes três passos.

- Passo 5: Mostrar às mães como Amamentar e como manter a lactação, Mesmo se Vierem a ser Separadas de Seus Filhos

Mães de bebês em cuidados especiais devem receber ajuda para iniciar e manter a produção de leite através da extração manual freqüente. Os profissionais de saúde devem ensiná-las como extrair o leite e como posicionar adequadamente o bebê ao peito. As mães precisam ser incentivadas a permanecerem o maior tempo possível ao lado de seu filho (OMS 1998).

Os resultados relativos a este passo demonstraram que, antes da implantação da IHAC no HURNP, essas orientações, quando seguidas, eram 
pontuais e realizadas por algumas enfermeiras, de acordo com o interesse da mãe pela amamentação, como mostra o depoimento de um dos profissionais:

Antes da IHAC não era trabalhada esta questão. Dependia da mãe, aquela que queria amamentar era orientada a ir para o banco de leite. Dependia mais da mãe do que da equipe (ET).

Após a IHAC, o conteúdo do Passo 5 passou a fazer parte da rotina sobre aleitamento materno na UTI/UCI neonatal. Os seguintes relatos mostram, com clareza, a importância deste passo para manter a lactação durante a internação do recém-nascido, bem como o compromisso da mãe com a rotina e a mudança de comportamento da equipe:

... a mãe passou a ter outro papel para nós, e não só para nós mas para a criança também. Houve uma mudança de visão da equipe não só da enfermagem, como da médica, assistente social, psicologia e fisioterapia (E7).

Após a IHAC mudou tudo, tanto com relação a orientação da mãe sobre como amamentar e também como manter a lactação (E6).

Com a implantação deste passo passamos a ter um índice de amamentação alta das crianças internadas na UTI... (E8).

Alguns fatores podem ter contribuido para o cumprimento deste passo na UTI/UCI neonatal do HURNP. O baixo nivel socioeconômico das 
mães, aliado ao impacto psicológico causado pelas condições clínicas de seu filho, incentivou a equipe a buscar mecanismos para aumentar o tempo de aleitamento das crianças internadas. As seguintes ações passam a ser desenvolvidas a partir de 1995 (SILVA et al. 1998):

1. Entrevista social durante o período de internação da mãe para identificar a situação socioecônomica, habitacional, profissional e familiar, com orientações sobre aleitamento materno e acompanhamento diário do recém-nascido.

2. Reunião semanal das mães e familiares das crianças internadas visando à resolução das dificuldades da mãe e/ou família.

3. Levantamento e classificação diária da situação do aleitamento materno de cada criança, além de uma avaliaçăo do envolvimento da mãe com seu filho.

4. Visita domiciliária para busca ativa das mães que apresentam dificuldade em amamentar e em formar vínculo com seu filho internado.

Outro fator fundamental para a implantação deste passo foi a integração da equipe do banco de leite do HURNP com os profissionais que 
atuam no Setor de Neonatologia, principalmente no que se refere ao incentivo e apoio ao aleitamento materno, como demonstra a fala a seguir:

Hoje existe integração entre UTI/UCI e BLH. Assim o BLH passa a ser um aliado neste processo, existe uma demanda da UTI neo ao BLH. Isto caracteriza aleitamento materno exclusivo... (E2).

A integração entre as equipes do banco de leite e da UTI/UCI neonatal contribuiu muito para que as orientações relativas à extração periódica do leite fossem cumpridas pelas mães. Isto é essencial para garantir o leite da própria mãe para o recém-nascido prematuro, de baixo peso ou que apresenta alguma patologia. Em situações clínicas que justificam a separação da mãe e filho, é imprescindivel que haja um monitoramento contínuo para manter a produção de leite enquanto o bebê permanecer impossibilitado de mamar no peito. Assim, recomenda-se o estímulo da sucção artificial por meio da extração manual freqüente a fim de aumentar ou manter a produção do leite na auséncia da criança. Vários estudos mostram a importância desta conduta.

MÉIER (1994) enfatiza que os recém-nascidos de baixo peso precisam ser alimentados com leite materno, cuja extração deve ser realizada precocemente após o parto, com técnica e freqüência adequadas para se obter produção de leite e se estabelecer a lactação. Recomenda que a extração de leite seja feita de oito a doze vezes por dia, principalmente na primeira semana.

DE CARVALHO et al. (1985) observaram que mães de 
prematuros internados, que extraiam o leite quatro ou mais vezes ao dia, apresentavam uma maior produção de leite do que as demais mães.

NYQVIST e EWALD (1997) compararam 148 recém-nascidos internados em UTI neonatal com 3516 recém-nascidos não internados. As mães dos recém-nascidos internados foram orientadas a realizar extração dé leite precoce e freqüente, pelo menos seis vezes ao dia. A duração do aleitamento materno exclusivo e parcial foi similar em ambos os grupos; sugerindo que a extração precoce e freqüente tenha ajudado a amenizar os efeitos da separação.

A maioria dos profissionais entrevistados reconheceu que este passo foi alcançado no Setor de Neonatologia. Apenas um profissional referiu dúvidas sobre as orientações dadas à mãe no momento da alta como mostra a sua fala:

Hoje tem uma rotina de orientação que eu tenho dúvida se é feita, por exemplo: eu gostaria que a mãe que sai de alta, seria importante que tivesse alguém destacado dentro da equipe para dar orientações a ela.Para a mãe do prematuro, que a criança não mama na sala de parto, teria que ser feito uma ordenha precoce. Isto é feito? Eu não sei dizer. Se é mantido a periodicidade desta ordenha enquanto a criança está internada eu também não sei dizer... (E8).

Este depoimento sugere que, apesar do avanço obtido após a IHAC, ainda há falta de coesão entre a equipe acerca das orientações sobre 
aleitamento materno que devem ser dadas às mães. Alguns profissionais de unidades de terapia intensiva neonatal, de forma não intencional, continuam limitando-se ao atendimento dos bebês, que na maioria das vezes encontram-se em condições críticas atribuindo as orientações sobre aleitamento materno, como função de outros profissionais da unidade. Esta falta de unidade da equipe merece atenção especial, para que não haja comprometimento do aleitamento materno e favorecimento do desmame precoce.

- Passo 6: não dar ao Recém-Nascido Nenhum Outro alimento ou líquido além do leite materno, a não Ser que Seja INDICADO PELO MÉdico

Os recém-nascidos com baixo peso, prematuros ou que possuem algum tipo de patologia, enfrentam problemas que dificultam a amamentaçăo, necessitando de cuidados especiais. A lactação pode demorar mais tempo para se estabelecer devido a fatores como a debilidade de reflexos para coordenaçăo da sucçăo/deglutiçăo/respiração, ou ainda, à falta de força suficiente para sugar. Contudo, a proteçăo exercida pelo aleitamento materno torna-se ainda mais importante nesta situaçăo do que em circunstâncias normais, e todo empenho deve ser feito para que as limitações sejam eliminadas e a criança possa ser amamentada (EUCLYDES 2000; VINHA et al. 1988).

A IHAC preconiza que, toda vez que se administra um alimento ou líquido diferente do leite materno, deva haver justificativa médica aceitável (OMS 1998). 
No entanto, ainda é comum, nas maternidades, o uso de "chucas" para a administração rotineira de soro glicosado e/ou suplementos aos recém-nascidos o que pode interferir no sucesso do aleitamento materno. A administração dessas substâncias aumenta o risco de infecções e, quando se utilizam mamadeiras, pode haver interferência na sucção do lactente. Pode, ainda, influenciar a freqüência das mamadas, contribuindo para o ingurgitamento mamário e conseqüente queda da produção de leite.

Os resultados desta pesquisa mostram que, antes da IHAC, a oferta de fórmulas aos lactentes internados na UTI/UCI neonatal do HURNP era tão comum a ponto de os profissionais responderem que o leite rotineiramente prescrito na época era o leite artificial, o que não corresponde à realidade. A análise dos prontuários dos recém-nascidos internados no setor de terapia intensiva neonatal, durante o ano de 1994, mostrou que o leite materno era a primeira opção das prescrições médicas. No entanto, a fórmula era rotineiramente oferecida, independentemente do que havia sido prescrito, havendo pouquíssimos prontuários com justificativas para tal conduta. Percebese, aqui, um conflito entre o que se preconizava na teoria com o que se vivenciava na prática, ou seja, prescrevia-se leite materno, porém a cultura dos profissionais de saúde, formada e sedimentada durante anos, conduzia-os ao uso indiscriminado de fórmulas, atitude que contava com a conivência daqueles que prescreviam o leite materno como primeira opção. A fala a seguir, ilustra a situação descrita: 
Após a IHAC se prescreve leite da própria mãe ou do banco e também é checado se aquilo que foi prescrito é o que é dado ao $R N$.. Isto é diferente de 1994, era prescrito leite materno mas na prática dava-se outro leite que freqüentemente era a fórmula. Apesar disso, não checávamos e também não cobrávamos dos funcionários o cumprimento da prescrição (E8).

Essas atitudes desarticuladas demonstram a falta de uma rotina estruturada e voltada para o aleitamento materno, justificando o baixo índice de AME $(1,9 \%)$ encontrado junto às crianças internadas na UTI/UCI neonatal em 1994. Estudos mostram o impacto negativo da oferta de fórmulas sobre a manutenção da amamentação.

LEEFSMA e HABATSKY (1990), em um estudo longitudinal em Israel, concluíram que os lactentes que recebiam fórmulas lácteas, uma ou mais vezes, diminuiam a probabilidade de aleitamento materno completo até seis semanas, sugerindo que quanto mais o lactente recebia fórmulas, maior era a probabilidade de não ser amamentado ao seio.

PÉREZ-ESCAMILLA et al. (1996) analisaram dados do Programa de Saúde da Familia de 1991/92 em Honduras, que incluía 714 mulheres com filhos de 0 a 6 meses de idade. A administração de água antes da apojadura se associava negativamente com aleitamento materno exclusivo; o uso de fórmulas lácteas associava-se negativamente com o aleitamento materno exclusivo e com o aleitamento materno em geral, e o uso de alimentos líquidos 
(chá e água glicosada) antes da apojadura, associava-se com o início tardio da lactação (depois de 24horas). Os autores concluíram que a utilização de alimentos pré-lácteos constitui fator de risco para o abandono precoce do aleitamento materno.

MARTIN-CALAMA et al. (1997), em estudo aleatório controlado, compararam um grupo de lactentes que recebia somente leite materno (grupo de intervenção) nos três primeiros dias $(n=87)$ com outro grupo que recebia soro glicosado em mamadeira (grupo controle), durante o mesmo periodo $(n=83)$. As mães dos lactentes foram entrevistadas por telefone no quinto mês pós-parto. 0 aleitamento materno artificial foi significativamente menos freqüente na quarta semana pós-parto no grupo de intervenção do que no grupo controle ( $18 \%$ versus $34 \%, p<0,05)$. Na $16^{a}$ semana, a prevalência da amamentação continuou sendo mais alta no grupo de intervenção ( $67 \%$ versus $43 \%, p<0,01)$.

Antes da IHAC, os efeitos dos substitutos do leite materno sobre a amamentaçăo eram praticamente ignorados pelos profissionais da Unidade de Neonatologia do HURNP mas, após a implantação da IHAC, observam-se mudanças na postura desses profissionais. Todos responderam que as prescriçőes médicas trazem como primeira opçăo o leite materno, seguido do leite do banco, sendo a fórmula a última opção. Sobre o tipo de leite que é oferecido na prática, foram unânimes em responder que seguem rigorosamente a prescrição médica. Houve uma adequação dos profissionais aos "Dez Passos" no sentido de oferecer ao recém-nascido exclusivamente leite humano, deixando 
a fórmula para situações excepcionais, sendo o seu uso sempre muito bem justificado no prontuário do paciente. Chama a atenção a afirmação de um profissional de que, hoje, a equipe de enfermagem alerta os médicos para prescreverem leite da própria mãe, revelando uma situação inversa a que existia antes da IHAC, em que o médico prescrevia o leite materno ou fórmula e a equipe de enfermagem oferecia fórmula, apesar de ser a segunda opção escrita na prescrição médica e mesmo assim, não havia questionamentos por parte dos médicos. $O$ depoimento a seguir ilustra essa situação:

...oferecemos ao bebê o leite que está prescrito. Hoje, nós da enfermagem, é que policiamos mais os médicos com relação a prescrever leite da própria mãe... (E7).

Há constatação de que a suplementação, em casos de indicação estritamente médica não altera a relação entre mãe e filho como também a confiança da måe, possibilitando a retomada do aleitamento materno logo que possivel, o que năo acontece quando o suplemento é dado de forma indiscriminada e irresponsável (BLOMQUIST et al. 1994).

O cumprimento do Passo 6, na UTI/UCI neonatal, contribuiu não só para aumentar a taxa de AME (de 1,9\% em 1994 para $41,7 \%$ em 1998), como também para a abolição total do uso exclusivo de fórmulas. Esse processo de retomada do leite materno para pacientes da UTI/UCI neonatal foi gradativo e contou com a participação do BLH. Apesar do BLH existir desde o final da 
década de 80 , portanto, antes de se desencadear o processo da IHAC, os resultados desta pesquisa mostraram que, em 1994, não se utilizava leite do banco para as crianças internadas na UTI/UCI neonatal. A maior parte do volume de leite do banco, até então, era destinada ao atendimento de crianças nascidas a termo na maternidade do HURNP, crianças em pós-operatório, crianças internadas na UTI pediátrica e solicitações de outros serviços.

De acordo com RÉA (1998), a Academia Americana de Pediatria, através de um grupo de trabalho sobre aleitamento materno, composto por grandes especialistas da área que se reuniram entre 1996 e 1997, divulgou oito recomendaçőes sobre a prática de amamentar e salientou o papel dos pediatras relativo ao aleitamento. Entre essas recomendações, há que se destacar o ponto inicial que recomenda: Leite humano é o alimento de preferência sempre, mesmo para recém-nascidos prematuros e de baixo peso...

Atualmente, sabe-se que bebês prematuros são capazes de responder adequadamente quando se utiliza leite humano, e que o leite produzido por suas mãe apresenta composição diferenciada em termos de aporte protéico-energético e de constituintes imunológicos. Tal leite ajusta-se às peculiaridades fisiológicas do metabolismo desses bebês, o que leva as unidades de terapia intensiva neonatal dos hospitais "Amigos da Criança" a utilizarem exclusivamente leite humano, obtendo excelentes respostas (ALMEIDA 1999). 
Neste contexto, é fundamental que uma instituição com UTI neonatal, tenha à disposição um banco de leite, preferencialmente instalado em suas dependências, a fim de atender os recém-nascidos de risco internados na UTI.

No HURNP, houve necessidade de reestruturação do BLH por ocasião do processo de implantação da IHAC. Seus objetivos foram revistos e priorizados os seguintes (OLIVEIRA et al. 1999):

1. Incentivar as mães a amamentar e garantir o aleitamento materno de bebês internados na UTI/UCI neonatal com ênfase para:

- A importância do aleitamento materno para o desenvolvimento de seu filho.

- Os procedimentos para manter a lactação enquanto separada do filho.

- O esgotamento periódico das mamas. O leite ordenhado é identificado, armazenado e posteriormente fornecido ao bebê de acordo com as suas necessidades.

- Os procedimentos das mães para a coleta do leite em sua casa, armazenamento e transporte do leite até o banco de leite.

- A importância de sua presença o maior tempo possível ao lado do filho. 
2. Manutenção do estoque de leite de mães de prematuros no banco de leite.

3. Avaliação periódica do aleitamento desses bebês pela equipe de atendimento ao recém-nascido internado.

Os depoimentos abaixo mostram a contribuição do BLH para a sustentação do AME dos recém-nascidos internados:

Hoje existe integração entre UTI/UCI e BLH. Assim o BLH passa a ser um aliado neste processo existindo uma demanda da UTI Neo ao BLH, isto caracteriza o AME, portanto, mesmo que a mãe não tenha ainda quantidade suficiente de leite, o BLH vem suprir esta falta (E2).

Antes da IHAC tínhamos pouco contato com o BLH, nós até esquecíamos que ele havia. Hoje a gente sabe mais em relação ao BLH. O banco é muito importante, porque trabalha o AM com as mães dos bebês internados além de fornecer leite materno para as crianças internadas. Se ele não tivesse a segunda opção não seria leite do banco e sim fórmula (E4).

A participação efetiva e o respaldo que o $\mathrm{BLH}$ tem dado para o cumprimento deste passo é essencial num hospital com as características do HURNP, que atende a maioria dos partos de risco do município e região. A 
garantia do fornecimento de leite humano para atender a todos os lactentes de risco depende da existência de um banco de leite.

É também de fundamental importância para a implantação e manutenção do Passo 6, o cumprimento da Norma Brasileira para Comercialização de Alimentos para Lactentes (BRASIL 1994), no que se réfere à proibição da distribuição de brindes e doação de amostras grátis de fórmulas nas unidades neonatais, pois pode induzir a mãe a optar pelo aleitamento artificial. Estudos mostram que mães que receberam amostra grátis de fórmula no hospital iniciaram o uso regular de fórmula mais precocemente e amamentaram por menos tempo do que as que não receberam (WRIGHT et al. 1996). Felizmente, após a vinda da IHAC, esta prática não se verifica mais na maternidade e Unidade de Neonatologia do HURNP.

\section{- Passo 9: não dar Bicos artificiais ou Chupetas a Crianças Amamentadas ao Seio}

Este passo era parcialmente observado em 1994, mas, ao término da implantação da IHAC, passou a ser integralmente cumprido, estando de acordo com o que preconiza a OMS (1998): as maternidades e unidades neonatais não devem oferecer bicos artificiais e mamadeiras aos bebês internados, uma vez que existem evidências científicas mostrando que o uso destes objetos compromete o aleitamento materno. 
Recomenda-se não usar mamadeiras e chupetas, especialmente no início da amamentação, porque essa prática, além de confundir o reflexo de sucção do recém-nascido, pode retardar o estabelecimento da lactação. Sabe-se que os movimentos que o bebê faz com a boca e a língua durante a sucçao do seio diferem daqueles utilizados para sugar a mamadeira. A sucção para retirada de leite do peito exige movimentos musculares para abaixar, protuir, elevar e retrair a mandíbula e movimentos da língua que fazem a ordenha do leite, enquanto que para a retirada do leite da mamadeira, não há necessidade dos movimentos de protusão e retrusão da mandíbula, nem dos movimentos da lingua. Conseqüentemente, recém-nascidos, após serem expostos à mamadeira, podem apresentar dificuldade em sugar o peito (NEWMAN 1990; NEWMAN 1993; DE CARVALHO 1995).

VICTORA et al. (1997) estudando o comportamento e atitudes de 450 pares de mãe-bebê, no Brasil, quanto ao uso de chupetas, concluiram que as chupetas contribuem para o desmame precoce entre as mães que não se sentem confortáveis em amamentar, mas não parecem afetar a duração do aleitamento entre as mães que acreditam na amamentação.

BARROS et al. (1995), em estudo realizado no Brasil com 605 recém-nascidos com um mês de idade, constataram que $23 \%$ usavam chupeta continuamente e $32 \%$ usavam parte do tempo. Aos quatro meses de idade, a prevalência do aleitamento materno exclusivo era mais alta entre os que não usavam chupeta $(45 \%)$ do que entre os que a usavam continuamente $(17 \%)$ ou 
parte do tempo $(26 \%)$. Os que usavam chupeta tinham quase quatro vezes mais probabilidade de abandonar a amamentação entre 1 e 6 meses de idade do que aqueles que não usavam.

LEITE et al. (1997) acompanharam 515 recém-nascidos com peso igual ou inferior a três quilos e suas respectivas mães, e concluíram que 0 uso de chupeta no primeiro mês de vida está altamente correlacionado com o desmame precoce. Portanto, recomendam que o uso de chupeta seja desaconselhado para crianças em aleitamento materno no primeiro mês de vida.

MÉIER (1988) estudando prematuros, constatou que esses recém-nascidos mostraram mais sinais de sofrimento, como a diminuição da $\mathrm{pO}_{2}$ transcutânea, quando sugavam na mamadeira do que quando sugavam no seio, indicando que o oferecimento da mamadeira ao prematuro antes de iniciar o aleitamento ao seio, é uma prática inapropriada.

No HURNP, o cumprimento deste passo pode ter sido facilitado pelo fato de existir, na época, uma tentativa de extinguir o uso de bicos e chupetas, substituindo-os por copinhos. O uso de copinhos ou xícaras é uma alternativa para os lactentes que não podem sugar diretamente ao seio, por ser um método artificial seguro para recém-nascidos de baixo peso e prematuros, até que eles estejam fortes e maduros o suficiente para mamar no peito. A indicação do uso de copos surgiu de estudos pioneiros de MUSOKE (1990) no Quênia, demonstrando que é mais fácil o aleitamento materno em prematuros quando não se usam bicos e mamadeiras. O uso do copo ou xicara substitui o 
uso da mamadeira, principalmente em países em desenvolvimento, onde convive-se com sérios problemas de higiene e nem sempre há disponibilidade de sondas gástricas. Assim, esta forma de amamentação torna-se simples, prática e econômica. Além disso, não interfere no modo de sucção que o bebe irá desenvolver quando vier a ser amamentado no peito, ao contrário da amamentação por mamadeira, uma vez que o tipo de sucção desenvolvida por esta via é diferente da sucção ao seio (LANG et al. 1994).

JONES (1994), em estudo realizado no Reino Unido, concluiu que prematuros alimentados com copos tinham maior possibilidade de continuar em aleitamento materno do que aqueles que haviam recebido mamadeira.

As repercussões negativas do uso indiscriminado de chupetas e mamadeiras não se limitam ao período de internação desses em unidades de terapia intensiva. Esta prática interfere, também, na amamentação futura e está relacionada à cárie rampante (MILNES 1996), à síndrome do respirador bucal, patologias do aparelho respiratório, deglutição atípica, maloclusão, disfunções crâneo-mandibulares e às dificuldades da fonação (DE CARVALHO 1995). Além disso, há maior exposição às nitrosaminas, substâncias cancerigenas presentes nas borrachas das mamadeiras (WESTIN 1990; GLÓRIA 1991).

Apesar das desvantagens do uso de bicos e chupetas, há estudos que defendem a utilização de chupetas em situações especiais, porque proporcionam a chamada sucção não nutritiva para bebês prematuros, que 
consiste em um padrão organizado e repetitivo de sugadas curtas e estáveis e pausas longas ou irregulares.

TIRADO et al. (1998) observou a influência da sucção não nutritiva no estado de consciência de recém-nascidos prematuros durante a alimentação. Aqueles que receberam sucção não nutritiva antes de 'serem alimentados, apresentaram um estado de consciência mais adequado durante a alimentação e, conseqüentemente, sugaram uma maior quantidade de leite num tempo menor.

GUINSBURG (1999) refere-se à ação da sucção não nutritiva em situações que resultam em dor do recém-nascido. $O$ uso da chupeta não diminui a dor, mas ajuda a criança a se organizar após um estímulo agressivo, minimizando as repercussões fisiológicas e comportamentais. $\mathrm{O}$ autor orienta a utilização desse recurso terapêutico durante a realização de pequenos procedimentos, como por exemplo, durante a coleta de sangue.

Em uma meta-análise de 19 trabalhos sobre o uso de sucção não nutritiva em prematuros, SHEET (1998) mostrou um decréscimo significativo no tempo de internação desses recém-nascidos, porém não revelou nenhum benefício com relação a outras variáveis como ganho de peso, saturação de oxigênio, tempo de trânsito intestinal, batimentos cardiacos e ingestão de energia. O estudo não menciona relação entre sucção não nutritiva e o aleitamento materno. 
No HURNP, os resultados mostram que antes da IHAC já havia uma tentativa de extinção de bicos e chupetas no Setor de Neonatologia, um processo bastante polêmico, como mostra a fala a seguir:

Antes da IHAC já havia uma iniciativa de retirar as mamadeiras e substituir por copinhos, então foi uma coisa tranqüila, uma coisa que fluiu. No inicio, é lógico, muitas resistências... (E2).

A existência dessa discussão, anterior à implantação da IHAC, facilitou o alcance do Passo 9 que foi considerado implantado por todos os entrevistados, resultando na mudança da rotina do setor e na conscientização das mães sobre a influência do uso de chupetas e bicos no aleitamento materno. Apesar dos profissionais terem considerado este passo de fácil implantação, há respostas conflituosas sobre situações em que é indicado o uso de chupetas. Todos dizem que a indicação se dá em circunstâncias especiais, porém nem todas as falas confirmam esta afirmação. Há depoimentos, como o que se segue, no sentido de que as indicações tidas como especiais precisam ser revistas e rediscutidas:

Eu acho que existe uma discussão que nós ainda não fechamos, $e$ temos que discuti-la, que é a indicação da suç̧ão não nutritiva. $E u$ não tenho indicado, mas existe na literatura a indicação. $O$ outro grande dilema é com aquelas crianças em que está contra indicado o aleitamento materno e a gente questiona porque ela recebeu leite no copo se em casa ela não irá receber. Mas eu não 
tenho indicado para essas crianças nem mamadeira e nem sucção não nutritiva... (E3).

As controvérsias a respeito do uso da chupeta em unidades de neonatologia e a preocupação com a sua interferência no aleitamento materno não ocorrem somente no HURNP. Há conflitos também na literatura, o que aponta para a necessidade de novos estudos neste sentido, uma vez que a sucção não nutritiva, desde que bem indicada, parece ser importante tanto para estimular prematuros como para ajudá-los em sua organização neurológica e emocional, após ser submetido a um estímulo agressor.

Outro ponto importante a ser considerado é que o uso, sem critério, de chupetas e mamadeiras nas maternidades, pode transmitir a impressão de que os profissionais de saúde o consideram seguro, o que poderia estimular ou reforçar essa atitude. Assim, é necessário que se cumpra rigorosamente a NBCAL, para que não haja distribuição gratuita de mamadeiras, bicos e substitutos do leite materno nas maternidades.

A seguir, serão discutidos os demais passos, obedecida a seqüência de apresentação dos "Dez Passos" da IHAC. 


\section{- Passo 1: Ter uma Norma Escrita Sobre Aleitamento, que DeVe Ser Rotineiramente Transmitida À Equipe de Saúde}

Os resultados mostram que as rotinas do Setor de Enfermagem da Unidade de Neonatologia do HURNP, vigentes em 1994, foram elaboradas em 1986 e constam do documento "Normas, Técnicas e Rotinas do Setor de Enfermagem da Unidade de Neonatologia do HURNP". Na análise desse documento, fica claro que não havia preocupação em priorizar a prática do aleitamento materno. Essa forma de normatização é introduzida normalmente, no setor, por razões científicas e organizacionais, que são aparentemente válidas, por transmitirem à equipe de saúde a sensação de que a existência das mesmas possibilita oferta de serviços que consideram eficientes e eficazes (OMS 1989).

Apesar da existência das normas referidas acima, observou-se desconhecimento destas por parte dos profissionais de saúde, que enfatizaram o aparecimento de norma específica sobre aleitamento materno, somente após o desencadeamento da IHAC no HURNP.

POWERS et al. (1994) discutem o papel que a rotina hospitalar exerce sobre os profissionais de saúde, que podem promover e apoiar práticas ótimas de aleitamento ou sabotar a decisão de amamentar. Assim, é fundamental que as rotinas explicitem claramente a prioridade institucional pelo aleitamento materno, que resultará em melhor qualidade do atendimento das mulheres e de suas familias. 
No HURNP, com a IHAC, foram elaboradas normas e rotinas especificas sobre aleitamento materno para a UTI/UCI neonatal, sala de parto e maternidade. A elaboração destas normas permitiu ampla participação dos profissionais dos diferentes setores e representou momentos importantes de aprendizado coletivo e trocas de experiências sobre aleitamento materno. Elas foram afixadas em cada um dos setores em locais visiveis, com conteúdo de fácil compreensão e contemplando todos os "Dez Passos".

Para os profissionais de saúde entrevistados, essas normas foram consideradas como um valioso instrumento para mudar a rotina de aleitamento materno na UTI/UCI neonatal do HURNP. Entretanto, há profissionais que as consideram importantes, mas ressaltam que deveriam estar associadas ao treinamento e reciclagem da equipe.

\section{- Passo 2: treinar toda a Equipe de Cuidados de Saúde, Capacitando-a Para implementar Esta norma}

Para a implementação de uma política de aleitamento materno, é necessário que os profissionais de saúde tenham informação sobre o assunto e uniformidade nas ações.

De acordo com a OMS (1998), todos os profissionais de saúde que tenham contato com mães e crianças, devem ser capacitados com base nos "Dez Passos". Esta capacitação, na IHAC, é dada através de um curso 
denominado "Manejo Clínico e Promoção do Aleitamento Materno", com carga horária mínima de 18 horas, sendo pelo menos três horas de prática sobre manejo clínico.

No HURNP, o inquérito realizado em 1995, revelou que apenas $10 \%$ dos profissionais haviam recebido algum tipo de treinamento em aleitamento materno o que, seguramente, refletia no desempenho da equipe. As conseqüências foram a pouca valorização do aleitamento materno e reduzida implementação de ações de estímulo à amamentação. Vários trabalhos demonstram o impacto positivo da educação continuada no desempenho dos profissionais de saúde.

NAYLOR et al. (1994) afirmam que a maioria dos profissionais de saúde considera o leite materno o alimento de escolha para a nutrição infantil, mas nem todos estão preparados para o manejo da lactação. Para corrigir esta falha, propõem a educação continuada, tanto para graduados como para graduandos, enfocando o aleitamento materno.

WINIKOFF et al. (1986) relatam o resultado de um projeto de combate aos obstáculos ao aleitamento materno em um grande hospital municipal, que teve a educação continuada e o treinamento intensivo da equipe médica e de enfermagem como meios de intervenção. A avaliação demonstrou que a taxa de AME aumentou de $15 \%$ para $46 \%$ após a intervenção, e o uso de fórmulas, embora tenha diminuido, não foi totalmente extinto, por falta de leite 
materno. Concluiram que o processo de combate aos obstáculos é difícil, porém não é impossivel.

WESTPHAL et al. (1995) realizaram um estudo sobre o impacto de um curso de treinamento em amamentação para equipes multiprofissionais, com duração de 133 horas, oferecido pelo Centro de Lactação de Santós, SP. Os conhecimentos foram medidos através de um questionário aplicado antes e depois do curso, e as atitudes mensuradas por meio de dinâmica de grupos. Os autores concluiram que o curso capacitou os participantes para promover as práticas de apoio ao aleitamento materno em suas instituições de origem.

RÉA e VENÂNCIO (1999) conduziram um estudo, em São Paulo sobre o impacto do "Curso de Aconselhamento em Amamentação". Os resultados mostraram que houve melhora significativa no desempenho do grupo exposto ao curso quanto às habilidades de aconselhamento. Após três meses do treinamento, houve uma discreta perda dos conhecimentos adquiridos, não havendo, entretanto, interferência significativa nas habilidades.

O segundo inquérito realizado no HURNP, em 1998, mostrou que $90 \%$ dos profissionais de saúde haviam recebido o treinamento proposto pelo Passo 2.

$\mathrm{Na}$ época em que os profissionais de saúde foram entrevistados, todos os funcionários da UTI/UCI já haviam sido treinados, o que os levou a entender que este passo já estava totalmente cumprido. Contudo, em um 
hospital universitário, dada a alta rotatividade de estudantes de enfermagem e de medicina que estagiam nessa unidade, o Passo 2 estará sendo continuamente desenvolvido. Até meados do ano 2001, cerca de 500 pessoas, entre profissionais e alunos, haviam sido treinados no HURNP.

Segundo a IHAC, para que este passo seja considerado cumprido, $100 \%$ da equipe deve estar treinada. Portanto, há que se buscar mecanismos para facilitar a sua execução em hospitais universitários, uma vez que a mudança de profissionais é uma realidade desse tipo de serviço.

As respostas dos profissionais entrevistados ressaltaram que o treinamento resgatou a importância da amamentação, permitiu a troca de experiências entre os participantes, possibilitou a uniformização das condutas e complementou as informações sobre o aleitamento materno.

Portanto, sob a ótica dos profissionais, os treinamentos têm tido um impacto positivo, por acrescentarem mais informações sobre o tema e, sobretudo, por ensinarem como fazer o manejo clínico do aleitamento materno.

Não há dúvidas que a maioria dos profissionais de saúde considera o leite materno o alimento ideal para crianças de zero a seis meses, mas, não se pode afirmar que eles estejam capacitados a orientar as mães sobre as diferentes situações que envolvem o aleitamento materno. Neste sentido, a realização do Passo 2 é fundamental para que os demais sejam cumpridos. 
Acredita-se que os treinamentos foram essenciais para as mudanças no padrão alimentar dos lactentes internados na UTI/UCI neonatal do HURNP.

\section{- Passo 3: Informar todas as Gestantes Sobre as Vantagens e manejo do Aleitamento materno}

O pré-natal é o tempo de preparo da mulher para o nascimento de seu filho, incluindo evidentemente a orientação e o preparo para a amamentação. Sendo assim, a percepção da gestante quanto ao atendimento e cuidados recebidos nesse período, podem refletir na maneira como ela cuidará do seu filho. Conseqüentemente, se essa percepção for positiva, poderá contribuir para o êxito da amamentação.

A OMS (1998) orienta que, o pré-natal deve incluir: informação sobre aleitamento materno, para incentivar as mães a amamentar; técnica de aleitamento materno, para capacitá-las e transmitir-lhes confiança; e, exame físico visando ao preparo das mamas para a amamentação.

Os resultados dos inquéritos realizados em 1995 e 1998 revelaram que, antes da implantação da IHAC no HURNP, poucas mães receberam orientação sobre aleitamento materno no pré-natal. Após a IHAC, todas as mães que haviam feito pré-natal no HURNP e tiveram seus filhos nesse hospital, haviam sido orientadas. 
As orientações sobre aleitamento materno no pré-natal são dadas pelos profissionais na perspectiva de que as mães terão seus bebês a termo o que, por um lado, facilita a amamentação. Por outro lado, as mães também têm a expectativa de que seu filho nasça sem problemas, o que nem sempre acontece. A mãe de um recém-nascido patológico pode manifestar sentimentos de frustração por seu bebê não ter nascido conforme ela havia idealizado. Tensão e preocupação pelos cuidados que o bebê exige, culpa pela patologia do filho, além do sofrimento pela separação do bebê durante a internação, são fatores que podem interferir intensamente na amamentação.

As respostas dos profissionais entrevistados mostraram que, apesar do Passo 3 se relacionar à educação das mães no pré-natal, seu conteúdo contribuiu para o resgate do aleitamento materno na UTI/UCI neonatal. Ficou evidente que as mães orientadas no pré-natal absorveram melhor as informações sobre aleitamento materno recebidas durante a internação de seu filho e apresentaram desempenho mais satisfatório na amamentação do que as mães não orientadas.

A literatura apresenta vários estudos que reforçam a importância das orientações sobre aleitamento materno durante o pré-natal.

GIUGLIANI et al. (1992), em estudo realizado no Rio Grande do Sul, mostraram que mães que não receberam orientação no pré-natal, apresentaram risco 1,7 vezes maior de desmamar nos três primeiros meses quando comparadas com as que receberam orientação. 
PUGIN et al. (1996), em estudo realizado em Santiago do Chile, avaliaram o efeito de um programa hospitalar de promoção do aleitamento materno com e sem educação no pré-natal. O programa incluia várias intervenções que englobavam os conteúdos dos "Dez Passos" da IHAC. Os autores concluíram que $\circ$ grupo que recebeu orientação pré-natal apresentou aumento do aleitamento completo até seis meses ( $80 \%$ versus $65 \%)$. Quando analisaram os resultados em separado, segundo a paridade, as diferenças foram significativas somente para as primiparas (94\% versus $57 \%)$. A influência da educação pré-natal sobre o aleitamento materno mostrou-se significativa e importante, especialmente entre mulheres sem experiência prévia com amamentação.

WILES (1984), em estudo realizado nos Estados Unidos, avaliou o efeito da educação em aleitamento materno durante o pré-natal sobre o sucesso da amamentação e a percepção da mãe sobre seu filho. A amostra consistiu de 40 mães primíparas, sendo que 20 receberam orientações sobre aleitamento materno no pré-natal e 20 fizeram parte do grupo controle. Os resultados mostraram que a educação sobre aleitamento materno no pré-natal exerce um efeito significativamente positivo, tanto no sucesso da amamentação como na percepção das mães sobre seu bebê.

Embora as orientações sobre aleitamento materno no pré-natal sejam imprescindiveis para o sucesso da amamentação, as mesmas devem ser reforçadas durante a permanência da mãe na maternidade e nos retornos ao 
ambulatório ou postos de saúde. A equipe de saúde deve estar alerta no pré-natal para a não utilização de materiais educativos fornecidos por indústrias de alimentos infantis e mamadeiras, assim como as gestantes não devem receber amostras grátis de substitutos do leite materno. $O$ uso desses materiais pode influenciar negativamente as mães para 0 aleitamento materno, particularmente para as mães de bebês prematuros, o impacto dessas propagandas poderá ser ainda maior uma vez que a permanência dela no hospital é freqüente durante a internação de seu filho.

\section{- Passo 4: Ajudar as mães a iniciar a Amamentação na Primeira Meia Hora Após o Parto}

O contato pele-a-pele da mãe com seu filho, logo após o nascimento, permite que o bebê fixe seu olhar no rosto da mãe; sobre o abdômen, ele busca o mamilo abrindo a boca e abocanhando o mamilo e a aréola para receber o colostro que Ihe dará imunidade. É um momento especial para que mãe e filho permaneçam juntos, tranqüilos, conhecendo-se e iniciando a amamentação (KLAUS e KENNEL 1983; RIGHARD e ALADE 1990).

A função dos profissionais de saúde que estão atuando na sala de parto neste momento é de apoio e ajuda à mãe, na tentativa de que resulte numa experiência satisfatória. De acordo com WINDSTROM (1990), a sucção precoce leva à descarga de oxitocina, que contribui para a descida do leite e atua na contração uterina, diminuindo a hemorragia pós-parto. A alimentação 
precoce e efetiva do recém-nascido com colostro previne a hipoglicemia e favorece o comportamento maternal.

Os resultados dos inquéritos realizados no HURNP mostraram que, antes da implantação da IHAC, o Passo 4 não era cumprido. Após a IHAC, ele passa a ser aplicado nas situações em que as crianças nascem em boas condições de vitalidade, uma vez que nem sempre é possivel fazê-lo em relação a mães de bebês que necessitam ser internados em unidades de terapia intensiva.

As respostas dos profissionais entrevistados reafirmaram a dificuldade de cumpri-lo com mães de recém-nascidos que são internados nessas unidades, dadas as condições de nascimento dos bebês. Eventualmente, isto é possivel em relação à criança internada na $\mathrm{UCl}$ neonatal e, quando ocorre, percebe-se que a descida do leite fica mais fácil, como mostram as falas a seguir:

... a partir do momento que nasce uma criança grave, muitas vezes este $R N$ é impedido do primeiro contato com a mãe na sala de parto, mas as crianças de UCI tem vários deles que são colocados para sugar e por alguma intercorrência foram levados à UCI. Portanto acho extremamente importante a mãe ter este contato dando início à interação mãe e filho e facilitando o início da descida do leite (E2).

As crianças que vão para a UTI às vezes pulam essa fase dada a sua gravidade, mas para as da UCI este contato com a mãe é 
muito importante porque acelera a produção de leite o que é muito importante para o bebê (E7).

A seguir, serão discutidos os Passos 7, 8 e 10, uma vez que os Passos 5,6 e 9 já foram analisados.

- Passo 7: Praticar o alojamento Conjunto - Permitir que a mãe e Bebé Permaneçam Juntos - 24 horas por Dia

\section{- Passo 8: Encorajar a Amamentação Sob livre Demanda}

A discussão dos Passos 7 e 8 se dará em conjunto porque $\circ$ cumprimento de ambos requer a presença da mãe junto ao seu filho.

O sistema de Alojamento Conjunto surgiu da necessidade de se criar condições que permitissem um relacionamento favorável entre mãe e filho desde os primeiros momentos após o parto, intensificando as suas relações. Este sistema contribui para a educação dos pais, proporcionando-Ihes o desenvolvimento de habilidades e segurança emocional. Permite também a proximidade da mãe com o recém-nascido e a flexibilidade de horário, o que possibilita que a amamentação ocorra de acordo com a demanda do bebê, conforme apregoa o Passo 8. 
A IHAC preconiza que os recém-nascidos normais permaneçam alojados com suas mães dia e noite, com intervalos de até uma hora para realização de procedimentos hospitalares (OMS 1998).

O HURNP foi o primeiro hospital do Paraná a implantar o sistema de alojamento conjunto, em 1974 (THOMSON 1996). Esta prática é adotada para recém-nascidos saudáveis; os que nascem prematuros, com baixo peso ou com alguma patologia, são internados na UTI ou UCI neonatal para tratamentos especiais.

É inquestionável a importância e a necessidade de interação precoce e contínua entre a mãe e o recém-nascido logo após o nascimento. Em se tratando de recém-nascidos de alto risco, este processo pode ficar prejudicado por um período indeterminado, dada a necessidade de internação em unidade de terapia intensiva. De modo geral, as unidades de terapia intensiva são bastante restritivas com relação aos horários de visitas.

ZIEGEL e CRANLEY (1985) alertam que as rotinas hospitalares privilegiam a eficiência e a conveniência de médicos e enfermeiros, o que vem há muito tempo prejudicando o vínculo familiar. Os pais têm sido separados um do outro e do bebê no momento do nascimento e em grande parte do período puerperal.

BELLI (1992), em pesquisa realizada em São Paulo sobre a assistência prestada ao recém-nascido em UTI neonatal, mostra que $70 \%$ dos 
enfermeiros entrevistados eram favoráveis ao estabelecimento de horários de visitas das mães. Constatou-se, ainda, que a permanência da mãe junto do filho internado era bastante restrita, sendo a "interferência nas atividades da equipe que assiste ao recém-nascido" a principal justificativa para essa conduta.

Os inquéritos de 1995 (THOMSON et al. 1995) e' 1998 (SENTONE e THOMSON 2000) mostraram avanços em relação a esses dois passos após a implantação da IHAC no HURNP. As respostas dos profissionais entrevistados nesta pesquisa revelam que, antes da IHAC, não se permitia o livre acesso da mãe à UTI/UCl neonatal. Segundo eles, houve modificação dessa rotina após a IHAC, mas pode-se observar contradições relativas aos horários de permanência da mãe no setor:

Antes da IHAC a mãe tinha acesso limitado pelas normas que determinavam que a mãe incomodava e atrapalhava o serviço. Depois da IHAC este papel mudou, a mãe passou a ter um papel importante não só para o bebê mas também para a equipe. Se a mãe não vem nós vamos atrás dela (E7).

Hoje a mãe pode chegar aqui as 8 horas da manhã e sair as 7 horas da noite... (E1).

Ela pode ficar aqui das 7 às 22 horas... (E4).

Percebe-se que, após a IHAC, houve progresso no sentido de se facilitar o acesso das mães na UTI/UCI neonatal, mas sua permanência no setor 
ainda é restrita, sob o argumento de que há horários de visitas pré-estabelecidos e de que a estrutura física do hospital não permite que elas fiquem ao lado do filho na maior parte do tempo, conforme mostram os seguintes relatos:

Hoje não tem tempo determinado, ela fica o tempo que quiser, só recomendamos que ela não venha em horários de pićos de trabalho e quando vamos fazer um procedimento ela é convidada a se retirar. Toda vez que ela vem pergunta se o momento é apropriado para ela entrar, mas é livre (E8).

O tempo fica a critério da mãe. À noite até as dez horas porque ela precisa descansar e o hospital não tem infra-estrutura para isto $(\mathrm{E} 7)$.

A função da equipe não deve se restringir apenas em ajudar o recém-nascido a sobreviver, mas criar empatia com a mãe, apoiando-a para criar laços com o filho (KLAUS e KENNEL 1992).

A IHAC teve um papel importante para que os profissionais da UTI/UCI do HURNP passassem a perceber a necessidade de mudanças de suas condutas relativas à presença da mãe junto ao seu filho, mas, apesar do avanço, ainda há muito por fazer. É preciso que as mães de recém-nascidos internados sejam esclarecidas quanto ao seu papel nessa situação especial; elas precisam sentir-se úteis aos seus filhos, sentir que eles Ihes pertencem. Esta aproximação aumentaria o vínculo afetivo e a humanização do cuidado neonatal, coritribuindo 
para aumentar ainda mais a taxa de aleitamento materno tão almejada para esse grupo de crianças. A readequação da estrutura física da UTI/UCI neonatal do HURNP para acomodar as mães está planejada para um futuro próximo, o que permitirá avanços ainda maiores para os Passos 7 e 8 .

- Passo 10: encorajar a formação de grupos de apolo ao am, para Onde as Mães DeVerão Ser Encaminhadas por Ocasião da ALta HOSPITALAR

O acompanhamento da mãe e da criança após a alta hospitalar é de extrema importância, principalmente nos primeiros meses de vida do lactente. Além do suporte ambulatorial oferecido pela instituição onde o bebê nasceu, a mãe deverá ser orientada para contatar grupos de apoio ao aleitamento materno que por ventura existam na comunidade.

Somente orientações dadas às mães no pré-natal e puerpério não garantem o sucesso da amamentação. Estudos mostram que, durante todo o período de amamentação, a mulher está sujeita a crises temporárias na lactação que podem propiciar o desmame, caso não haja orientação adequada. Daí, a importância do apoio não só de um profissional de saúde, como também de membros da própria comunidade engajados na luta pelo aleitamento materno (VERRONEM 1982; SOUZA 1996).

DAVIES-ADETUGBO (1996) avaliou um programa de educação pós-natal em aleitamento materno desenvolvido na Nigéria por agentes de saúde 
da comunidade. A prevalência do aleitamento materno completo aos quatro meses foi significativamente maior no grupo que recebeu intervenção $(40 \%)$ do que no grupo controle (14\%).

Estudo no México mostrou que mães que recebiam seis visitas domiciliares por promotores treinados em aleitamento materno apresentavam maior probabilidade de aleitamento materno exclusivo aos três meses de vida (72\%) do que aquelas que recebiam somente três visitas dos mesmos promotores $(50 \%)$. No grupo controle, somente $7 \%$ encontravam-se em aleitamento materno aos três meses (MORROW 1996).

De acordo com Leite et al. (1998), citados pela OMS (1998, p.85), resultados preliminares de um estudo controlado, realizado em Fortaleza, indicam que promotores treinados em aleitamento materno que atuam junto a mães na comunidade contribuem para $\circ$ aumento das taxas de aleitamento materno exclusivo.

No HURNP, o inquérito realizado antes da IHAC mostrou que o banco de leite humano era o ponto de referência de encaminhamento das mães após a alta da maternidade. $O$ inquérito realizado depois da implantação da IHAC e as respostas dos entrevistados nesta pesquisa mostraram que os encaminhamentos são feitos para os serviços de suporte ao aleitamento materno existentes na Universidade (ambulatórios de Puericultura e de Neonatologia; Clínica de Lactação e Banco de Leite Humano) por serem públicos e estarem ao alcance da população atendida na maternidade do HURNP. Além desses 
serviços, os encaminhamentos podem ser feitos às Unidades Básicas de Saúde, dependendo do estado de saúde da criança na alta hospitalar.

Para os bebês de risco, é fundamental contar com serviços ambulatoriais de apoio, tendo em vista a necessidade de acompanhamento dessas crianças e considerando a importância do aleitamento materno para a saúde das mesmas. A rotina ambulatorial do HURNP para esses bebês consiste no encaminhamento de todos os prematuros para o Ambulatório da Neonatologia e, se necessário, para a Clínica de Lactação. Todos os prematuros extremos (< 1500g) são encaminhados para o Ambulatório de Neonatologia e para a Clínica de Lactação.

A Clínica de Lactação, criada em 1995, funciona no Ambulatório do Hospital de Clínicas da Universidade Estadual de Londrina e oferece atendimento multiprofissional para dirimir dúvidas e solucionar os principais problemas ligados ao aleitamento materno, além de dar atendimento específico para os prematuros nascidos no HURNP com peso abaixo de 1500 gramas.

Há um compromisso dos profissionais da UTI/UCI neonatal para que a mãe receba todas as orientações relativas ao aleitamento materno durante a internação e por ocasião da alta do bebê, cabendo aos serviços ambulatoriais reforçar essas orientações e ajudar as mães na solução de eventuais problemas relativos ao aleitamento materno depois da alta hospitalar.

Apesar dos avanços relativos em aleitamento materno no municipio, atualmente não existem, em Londrina, grupos comunitários de apoio à 
amamentação, conforme preconiza a IHAC. É preciso desenvolver políticas públicas de saúde voltadas para o aleitamento materno, com participação intensa de profissionais dos serviços de saúde, das instituições de ensino e da comunidade para que tais grupos se estruturem, consolidem e prolifeiem, atuando na promoção, proteção e apoio ao aleitamento materno.

\subsubsection{A FreqüÊncia do Aleitamento Materno nos Primeiros Seis Meses de Vida}

O impacto da IHAC sobre a duração do aleitamento materno, tanto para crianças a termo como aquelas de risco, que necessitam de internação após o nascimento, não tem sido um aspecto muito explorado nos estudos sobre as repercussões da IHAC. Na literatura consultada, não há dados quanto à sua influência sobre a duração do aleitamento materno e, portanto, torna-se difícil uma análise comparativa entre os resultados encontrados nesta pesquisa e resultados de outros estudos.

A maioria dos estudos existentes resulta da avaliação das taxas de aleitamento materno em serviços de saúde, porém questões metodológicas dificultam a comparação dos estudos realizados em diferentes localidades do país, uma vez que são citadas diferentes terminologias adotadas para especificar os tipos de aleitamento materno. Diferenças também ocorrem na forma de coletar e analisar os dados disponiveis. Nos estudos transversais, a zoleta de 
dados sobre a freqüência de crianças amamentadas pode ser feita com base no tipo de alimentação que a criança recebeu no dia anterior à entrevista ou, ainda, com base em dados coletados de forma retrospectiva e analisados pela técnica de tábua de vida (PASSOS et al. 2000).

Nesta pesquisa, verificou-se que no final do segundo mês de vida, apenas $22,6 \%$ das crianças encontravam-se em aleitamento materno exclusivo em 1994 e 46,1\% em 1998, duplicando o número de crianças nesta modalidade de aleitamento. No final do quarto mês, o número de crianças em aleitamento materno exclusivo, em 1998 , aumentou ainda mais $(28,6 \%)$, quando comparado com $1994(11,7 \%)$. Ao final do quinto mês o aumento foi de $4,0 \%$ para $15,2 \%$. Estas mudanças resultaram no aumento da mediana da duração do aleitamento materno exclusivo, que era de 12 dias, em 1994, para 45 dias em 1998.

A elevação da mediana do aleitamento materno exclusivo torna-se bastante significativa em se tratando de recém-nascidos prematuros e de baixo peso. Estudo realizado por HYLANDER et al. (1998) na Unidade de Terapia Intensiva Neonatal do Centro Médico da Universidade de Georgetown, demonstrou o efeito do leite humano na incidência de infecções em crianças de muito baixo peso durante sua hospitalização. A incidência de infecções em crianças que receberam leite humano foi de $29,3 \%$ e, em relação às crianças que receberam fórmula, foi de $47,2 \%$. A incidência de sepsis e meningite foi de $19,5 \%$ em crianças que receberam leite humano e de $32,6 \%$ nas crianças 
alimentadas com fórmula, mostrando que as infecções foram significativamente reduzidas nas crianças alimentadas com leite humano.

Segundo LEVIN (1999), a IHAC tenderia a beneficiar somente os bebês saudáveis uma vez que apenas as rotinas das maternidades contemplaria os "Dez Passos" enquanto uma unidade de terapia intensiva neonatal, no mesmo hospital, não responderia a todos os passos. Entretanto, os resultados desta pesquisa contrariam a opinião apresentada por esse autor, uma vez que a implantação dos "Dez Passos" da IHAC na UTI/UCI neonatal do HURNP resultou no aumento dos índices do aleitamento materno exclusivo e aleitamento materno em geral.

Estes resultados são de extrema importância, pois o leite produzido pelas mães de prematuros traz benefícios não apenas por apresentar maiores quantidades de fatores imunológicos mas, também, pelo menor risco da presença de contaminantes. As crianças prematuras e de baixo peso nem sempre são beneficiadas pela transferência de imunoglobulinas através da placenta que ocorre após 34 semanas de gestação. Por estarem expostas a um ambiente patogênico durante a internação em unidades de terapia intensiva, é fundamental que elas recebam os fatores de proteção através do leite da própria mãe como primeira opção ou leite humano de banco de leite como segunda opção, desde que seja compatível com a idade gestacional do recémnascido. 
A decisão de cumprir todos os passos relativos aos recémnascidos de risco e a mudança de postura da equipe frente ao aleitamento dessas crianças possibilitaram a melhoria dos índices de aleitamento materno num grupo de crianças onde a amamentação representa dificuldades peculiares, seja para o recém-nascido, para a mãe, para a familia ou ainda para a equipe de saúde que assiste este recém-nascido durante $\circ$ parto e $\circ$ período de internação.

Aumentar os índices de aleitamento materno durante a internação não basta, é preciso garantir mecanismos eficientes de acompanhamento da mãe e da criança, com o objetivo de se monitorar os indices de aleitamento materno, bem como possibilitar à mãe orientação e apoio caso ela apresente dúvidas relativas à amamentação. Após a alta hospitalar da criança, as mães devem ser orientadas a retornar ao ambulatório para reavaliação após cinco ou sete dias, considerando que é nos primeiros dias, em casa, que surgem problemas e dúvidas que podem interferir na amamentação. É essencial que, em todos os retornos, o profissional de saúde reforce as orientações relativas à amamentação.

Aumentar as taxas de aleitamento materno enquanto o bebê ainda se encontra hospitalizado e durante o seguimento ambulatorial pós-alta, implica também assegurar os benefícios que esta prática representa a longo prazo para o desenvolvimento imunológico, emocional, nutricional e neurológico dessas crianças. 


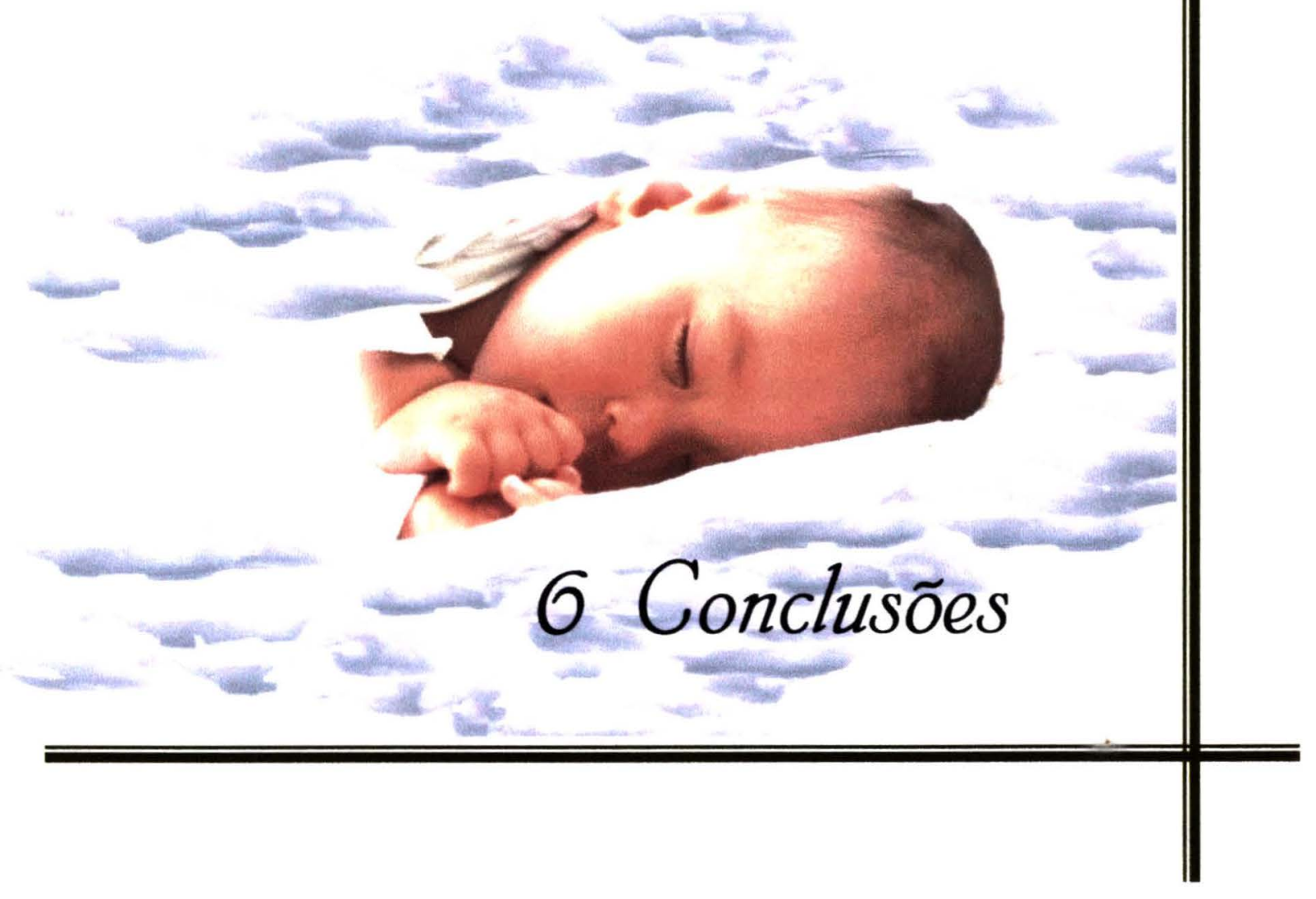


- O processo de implantação da IHAC no HURNP iniciou-se em 1995, concretizou-se no final de 1997 e, no início do ano 2000, o hospital foi credenciado como "Hospital Amigo da Criança". Na unidade de neonatologia, em particular observaram-se mudanças importantes nas rotinas referentes à prática do aleitamento materno, segundo apontam relatos de profissionais de saúde que vivenciaram o processo de implantação da IHAC nesta unidade.

- A partir de 1995, início da implantação da IHAC no HURNP, houve um aumento gradual na utilização de leite humano exclusivo para os recém-nascidos internados na unidade de neonatologia e abandono da utilização de fórmulas como única fonte de alimentação.

- Foram constatadas mudanças significativas no regime alimentar dos recém-nascidos internados na UTI/UCI neonatal do HURNP nos anos de 1994 e 1998, destacando-se um aumento expressivo de crianças que passaram a receber exclusivamente leite humano (de 1,9\% em 1994 para 41,7\% em 1998). Em 1994, cerca de $80,0 \%$ das crianças recebiam leite da própria mãe associado à fórmula; já em 1998, a combinação leite da própria mãe e fórmula virtualmente desaparece $(0,6 \%)$, sendo 
substituída pela combinação leite da mãe, do banco de leite e fórmula.

- A combinação de leite da mãe, do banco de leite e fórmula, recebida por cerca de $58,0 \%$ das crianças internadas em 1998 , pelo menos $2 / 3$ do volume desta associação era composta por leite da própria mãe e o restante do banco de leite e fórmula, evidenciando maior participação da mãe e do banco de leite e menor utilização de fórmulas.

- Em 1994, cerca de $18,0 \%$ das crianças internadas na Unidade de Neonatologia do HURNP recebiam exclusivamente fórmulas sendo que, em 1998, ocorreu abolição total da utilização de fórmulas.

- Não houve diferença significativa quanto à freqüência do aleitamento materno nos primeiros seis meses de vida entre 0 grupo de crianças estudadas em 1994 e 1998; o tempo mediano do aleitamento materno nos primeiros seis meses de vida, foi de 176 dias em 1994, para 180 dias em 1998. 
- Houve aumento significativo na frequência do aleitamento materno exclusivo nos primeiros seis meses de vida entre os anos de 1994 e 1998. Ao final do segundo mês de vida, somente $22,6 \%$ do grupo de crianças de 1994 encontravami-se em AME, contra $46,1 \%$ em 1998. Ao final do quarto mês de idade, $11,7 \%$ das crianças do grupo estudado em 1994 encontravam-se em AME enquanto que em $1998,28,6 \%$ das crianças continuavam em AME. Com cinco meses de vida, apenas $4,0 \%$ das crianças de 1994 encontravam-se em AME, enquanto, em 1998, 15,2\% recebiam exclusivamente leite materno. O tempo mediano do AME nos primeiros seis meses de vida, que era de 12 dias em 1994, aumentou para 45 dias em 1998. 


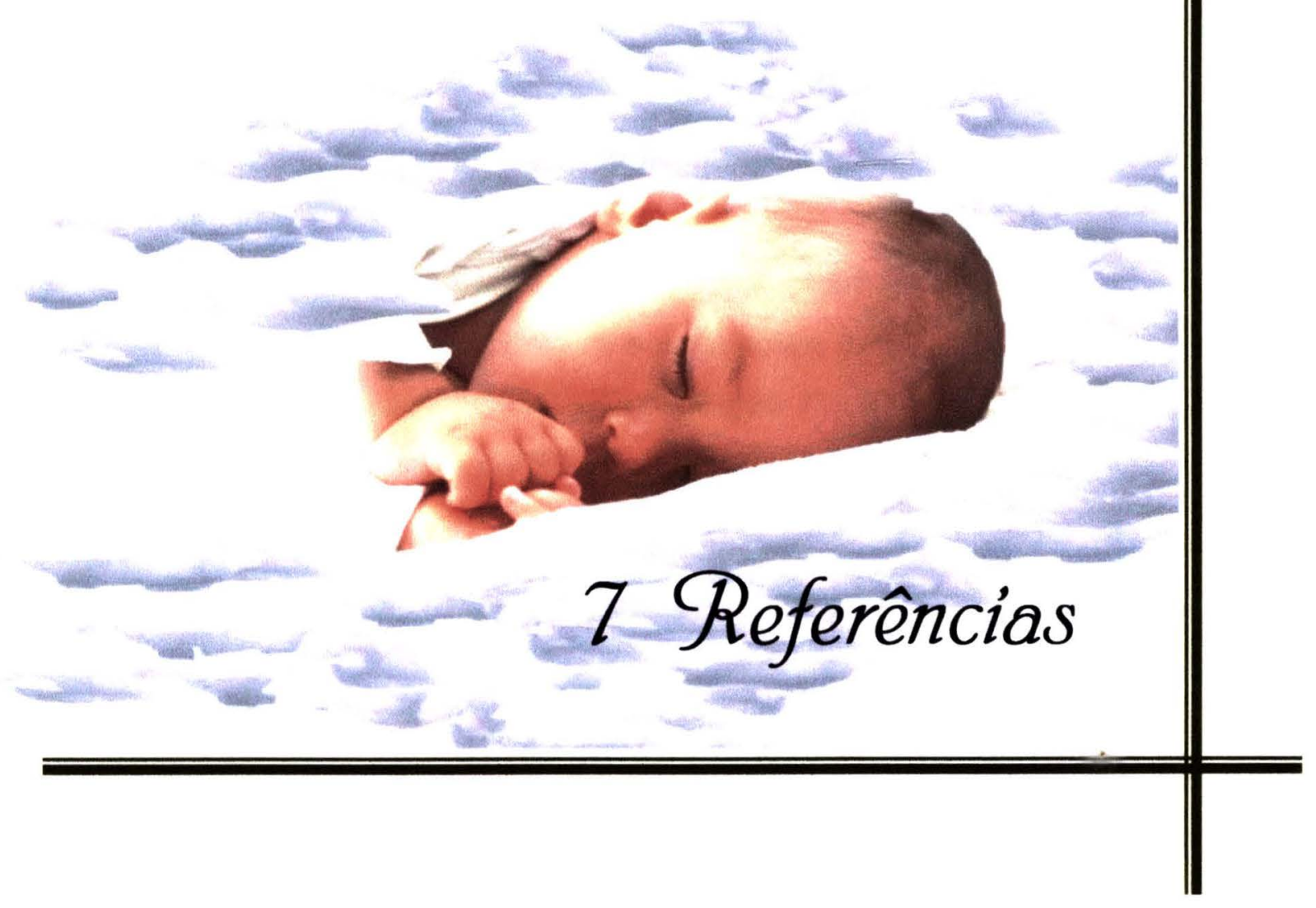


Akré J. Alimentação infantil: bases fisiológicas. São Paulo: Instituto de Saúde; 1994.

Almeida JAG. Amamentação: um híbrido natureza-cultura. Rio de Janeiro: Fio Cruz; 1999.

American Academy of Pediatrics. Committee on nutrition. Nutritional neéds of low-birth-weight infants. Pediatrics 1985; 976-86.

American Academy of Pediatrics. Breastfeeding and the use of human milk. Pediatrics 1997; 100(6):1035-39.

Baltar CAF. Reflexões sobre a utilização de leite humano em UTI neonatal. Rio de Janeiro, 1997. [Monografia. Instituto Fernandes Figueira Universidade do Rio de Janeiro].

Barros FC et al. The impact of lactation centres on breastfeeding patterns, morbidity and growth: a birth cohort study. Acta Paediatr. 1995, 84:1221-26.

Barros MD, Yamashiro G, Barreto O; Sampaio MMS. Características do leite de mães de recém-nascidos de baixo peso. J Pediatr 1984, 6:53-7.

Belli MAJ. Assistência à mãe de recém-nascido internado na UTI neonatal: experiências, expectativas e sugestões manifestadas por mães e enfermeiros. São Paulo; 1992. [Dissertação de Mestrado - Escola de Enfermagem da Universidade de São Paulo].

Blaww R, Alberse EC, Beneke T, Lombard CJ, Laubscher R, Hough FS. Risk factors for the development of osteoporosis in South Africa population. South Afr Med J 1994; 84:328-32. 
Blomquist HK, Jonsbo F, Serenius F, Persson LA. Supplementary feeding in the maternity ward shortens the duration of breast feeding. Acta Paediatr 1994; 83:1122-26.

Bener UM, Denic S, Galadari S. Longer breastfeeding and protection against childhood leukaemia and lymphomas. Eur J Cancer 2001; 37:234-8.

Bier JAB, Fergusson A, Anderson L, Solomon E, Voltas $C$ et al. Breastfeeding of very low birth weight infants. J Pediatr 1993; 123:773-8.

Brasil. Ministério da Saúde. Coordenadoria de Saúde Materno-infantil. Grupo de Defesa de Saúde da Criança. Iniciativa "Hospital Amigo da Criança": Questionário de Auto-Avaliação de Hospitais. Brasília (DF); [1992](a).

Brasil. Ministério da Saúde. Programa Nacional de Incentivo ao Aleitamento Materno. Grupo de Defesa de Saúde da Criança. Iniciativa "Hospital Amigo da Criança": Questionário de Avaliação Global de Hospitais. Brasilia (DF); [1992](b).

Brasil. Ministério da Saúde. Instituto Nacional de Alimentação e NutriçãoINAN. Conselho Nacional de Saúde-CNS. Norma Brasileira para Comercialização de Alimentos para Lactentes $-3^{a}$ ed. Brasilia (DF); 1994.

Brasil. Ministério da Saúde. Secretaria da Criança e Aleitamento Materno. Departamento de Geståo de Políticas Estratégicas. Secretaria de Políticas de Saúde. Recomendações Técnicas para o Funcionamento de Bancos de Leite Humano. $4^{\text {a }}$ ed. Brasília (DF);1999.

Brasil. Ministério da Saúde. Secretaria de Assistência à Saúde. Conselho Nacional de Saúde. Programa Nacional de Doenças Sexualmente Transmissiveis. Diretrizes e normas regulamentadoras de pesquisa envolvendo seres humanos. Brasília;1997. 
Brun JG, Nilssen S, Kuale G. Breastfeeding, other reproductive factors and rheumatoid arthritis: a prospective study. Br J Rheumatol 1995; 34:542-6.

Candella CLM. A amamentação e manutenção da lactação relacionadas com a condição e o conhecimento de mães no momento da alta de seus filhos em berçário de alto risco. São Paulo; 1995. [Monografia - Escola de Enfermagem da Universidade de São Paulo].

Cattaneo A, Davanzo R, Uxa F, Tamburlini G. Recommendations for the implementation of Kangaroo Mother Care for low birth weight infants. Acta Paediatr 1998; 87:440-5.

Chang-Claude J, Eby N, Kiechle M, Bastert G, Becher H. Breastfeeding and breast cancer risk by age 50 among women in Germany. Cancer Causes Control 2000; 11:687-95.

Chua S, Arulkumanan S, Lim I, Selamat N, Ratnam SS. Influence of breastfeeding and nipple stimulation on postpartum uterine activity. BR J Obstet Gynaecol 1994; 101:804-5.

Correa AMS. Aleitamento materno: estudo sobre o impacto das práticas assistenciais. Campinas; 1996. [Tese de Doutorado - Faculdade de Ciências Médicas da UNICAMP].

Cummings RG, Klineberg RJ. Breastfeeding and other reproductive factors and the risk of hip fracture in elderly women. Int J Epidemiol 1993; 2:684-91.

Davies-Adetugbo AA. Promotion of breast feeding in the community: impact of health education programme in rural communities in Nigeria. J Diarrhoeal Dis Res 1996; 4(1):5-11. 
Davis MK, Stavitz DA, Graubard BI. Infant feeding and childhood cancer. Lancet 1998; 2:365-8.

De Carvalho GD. A amamentação sob a visão funcional e clínica de odontologia. Rev Secretários Saúde 1995; 10:12-3.

De Carvalho $\mathrm{M}$ et al. Frequency of milk expression and milk production by mothers of nonnursing premature neonates. Am J Dis Child 1985; 139:48385.

Dean, $A G$ et al Epi Info, version 6.0b a Word processing, database and statistics program for epidemiology on microcomputers. Atlanta: Centers for Disease Control and Prevention, 1995.

Duncan B, Eny J, Holberg CJ, Wright AL, Martinez FD, Taussing LM. Exclusive breast-feeding for at least 4 months protects against otitis media. Pediatrics 1993; 91:867-72.

Euclydes MP. Aleitamento materno. $2^{a}$ ed. Viçosa (MG):Suprema; 2000. Nutriçăo do lactente: base científica para uma alimentação adequada; p. 259346.

Favoreto J, Thomson Z. Avaliação do programa de estímulo ao aleitamento materno do Hospital Universitário Regional do Norte do Paraná, Londrina. J Pediatr 1991; 70:138-49.

Ford RPK, Taylor BJ, Mitchell EA, Enrigth SR, Steward AW, Becrof DM et al. Breastfeeding and the risk of sudden infant death syndrome. Int J Epidemiol 1993; 22:885-90. 
Gil CRR. Avaliação de projetos: análise do Projeto UNI-Londrina. A avaliação como instrumento da ação. Londrina; 1995. [Dissertação de Mestrado - Universidade Estadual de Londrina].

Gimeno SG, Souza JMP. Amamentação ao seio com leite de vaca e o diabetes mellitus tipo 1. Rev Bras Epidemiol 1998; 1:4-13.

Giugliani ERJ, Issler RMS, Justo EB, Seffrin CF, Hartmann RM, Carvalho NM. Risk factors for early termination of breast feeding in Brazil. Acta Paediatr $1992 ; 8: 482-7$.

Glória MBA. N-nitrosamines in baby bottle nipples and pacifiers. Cienc Cult $1991 ; 43(1): 44-7$.

Goldman AS, Garza C, Nichols B, Jhonson CA, Smith EO, Goldblum RM. Effects of prematurity on the immunologic system in human milk. J Pediatr $1982 ; 101: 901-6$.

Gonzáles LH, Morales TT, Pereya JT. Alimentacion de prematuros sanos con leche de su propria madre. Rev Child Obstet Ginecol 1991; 56:206-9.

Gross SL, Geler N, Tomarelli RM. Composition of breast milk from mothers of preterm infants. Pediatrics 1981; 68:480-3.

Guinsburg R. Avaliação e tratamento da dor no recém-nascido. J Pediatr 1999; 75(3):149-60.

Hardy E, Faundes A, Marussi ES, Algaba MFO, Pinotti JA. Aleitamento materno e câncer de mama. Estudo caso controle desenvolvido em Campinas- São Paulo. Rev Bras Ginec Obstetr 1993; 5:83-7. 
Hylander MA, Strobino DM, Dhanireddy R. Human milk feeding and infection among very low birth weight infants. Pediatrics [electronic article] 1998;102(3). Avaliable from:< URL:http://mww. pediatrics.org [1999 JUL 14].

Instituto Brasileiro de Geografia e Estatística. Cidades: O Brasil, município por município. [on line] 2000. Disponivel em: <URL:http://mww1.ibge.gov.br/cidadesat/ [2001 Out 02].

Jones E. Breastfeeding in the preterm infant. Modern midwife 1994; 4(1):2226.

Jones G, Riley M, Dwyer T. Breastfeeding in early life and bone mass in prepubertal children: a longitudinal study. Osteoporos Int 2000; 11:146-52.

Karjalainen j, Martin JM, Kinip M, llonen J, Robinson BH, Savilahti E et al. A bovine albumin peptide as a possible trigger of insulin-dependent diabetes mellitus. N Engl J Med 1992; 327:302-7.

Kennel JH, Klaus MH. Vínculo afetivo: observações recentes que alteram o cuidado perinatal. Pediatr Rev 1998;19(1):4-12.

King FS. Como ajudar as mães a amamentar. Trad. de Z. Thomson e ON Gordan. Brasília:Ministério da Saúde, 2001.

Klaus $\mathrm{MH}$, Kennel JH Parent to infant bonding:setting the record straight. J Pediatr 1983; 102:575.

Klaus $\mathrm{MH}$ e Kennel JH. Pais/bebê: a formação do apego. Porto Alegre, Artes Médicas, 1992. 
Kummer SC, Giugliani ERJ, Susin LO, Folletto JL, Lermen NR, Wu VYJ et al. Evolução do padrăo de aleitamento materno. Rev Saúde Pública 2000; $34(2): 143-8$.

Lang S, Lawrence CJ, Orme RCL. Xícara: um método alternativo para alimentação infantil. Arch Dis Child 1994; 71:365-69.

Lawrence RA e Lawrence RM. Breastfeeding: a guide for medical profession. $5^{\text {th }}$ ed. Mosby: St. Louis; 1999. Psychology impact of breastfeeding; p.197-232.

Leefsma $M$ e Habatsky $T$. The influence of hospital routine on successful breastfeeding. In: Freier S, Eidelman AL, eds. International Symposium on Breastfeeding. Human milk - It's biological and social value. Amsterdam, Excerpa Medica, 1990:309-13.

Leite AJM Cunha AJLA Machado M Capiberibe AL Rodrigues RC Braga D et al Uso de chupeta e desmame precoce no primeiro mês de vida. In: Anais do V Encontro Nacional de Aleitamento Materno. Londrina (Pr); 1997:28.

Lemons JA, Moye L, Hall D, Simmons M. Differences in the composition of preterm and term human milk during early lactation. Pediatr Res 1982;16:1137.

Levin A Humane neonatal care initiative. Acta Paediat 1999; 88:353-5.

Londrina 67: Londrina 67 Anos. Folha de Londrina (suplemento especial) 2001 dez 10; p.1-8.

Lucas A, Cole TJ. Breast milk and neonatal necrotising enterocolitis. Lancet $1990 ; 336: 1519-23$. 
Lucas A, Morley R, Cole TJ, Lister G, Leeson-Payne C. Breast milk and subsequent intelligency quocient in children preterm. Lancet 1992; 339:261-4.

Luther $\mathrm{CH}$; Pérez-Escamilla R; Segall A; Sanghvi T; Teruya K; Wickham C The effectiveness of a hospital program to promote exclusive breast-feeding among low-income women in Brazil. Am. J. Public Health, 87(4): 659-63, 1997.

Marcolini TT. Amamentação. In: Noronha DT; Lopes GP; Montgomery M. Tocoginecologia psicossomática. São Paulo: Amed; 1993. cap.12, p.83-8.

Martin-Calama J, Bunel J, Valero MT, Labay M, Lasarte JJ. The effect of feeding glucose water to breastfeeding newborns on weight, body temperature, blood glucose, and breastfeeding duration. J Hum Lact. 1997,13(3):209-13.

Méier P. Bottle and breast-feeding: effects on transcutaneous oxygen pressure and temperature in preterm infants. Nurs Res 1988; 37(1):36-41.

Méier $\mathrm{P}$. Breast feeding the premature baby: a research review. News brief. 1994; (1):2-5.

Milnes AR Description and epidemiology of nursing caries. J Public Health Dent 1996; 56(1):38-50.

Ministério da Saúde. Metas da cúpula mundial em favor da infância. Avaliação da meia década, 1990-1995. Brasília (DF);1997.

Ministério da Saúde. Pesquisa de prevalência do aleitamento materno nas capitais e no Distrito Federal. Brasília (DF); 2001. 
Monteiro CA, Rea MF, Victora C. Can infanty mortality be reduced by promoting of breastfeeding? Evidence from São Paulo city. Health Policy Plann 1990; 5:23-9.

Moreira MEL. Avaliação do crescimento e da composição corporal de recém-nascidos pré-termo. Ribeirão Preto; 1997. [Tese de Doutorado Faculdade de Medicina de Ribeirão Preto da USP].

Morrow AL The effectiveness of home-based counseling to promote exclusive breastfeeding among Mexicans mothers. In: Exclusive breastfeeding promotion: a summary of findings from EPB's applied research program (1992-1996). Wellstart international's Expanded Promotion of Breastfeeding (EPB) Program (unpublished document).

Musoke RN Breastfeeding promotion: feeding the low birth weight infant. Int $\mathrm{J}$ Gynecol Obstet. 1990; 31(suppl. 1):57-59.

Naylor AJ, Creer AE, Lopez GW, Dixon S. Lactation management education for physicians. Semin Perinatol. 1994; 18 (6): 525-531.

Newman J. Breast-feeding problems associated with the early introduction of bottles and pacifiers. J Hum Lact 1990; 6:59-63.

Newman J. Nipple confusion. Letter to the Editor. Pediatrics 1993; 92:297-8.

Novaes HMDN Avaliação de programas, serviços e tecnologia em saúde. Rev Saúde Pública 2000; 34(5):547-59.

Nyqvist KH, Ewald U. Successful breast feeding in spite of early motherbaby separation for neonatal care. 1997; 13:24-31. 
Oliveira MMB; Sentone ADD; Brenes MIM; Silva VES; Assis RO; Oliveira CH Desmistificando uma regra geral: Como ações de apoio 'a amamentação da mãe do prematuro também podem aumentar o seu tempo de lactação. In: Anais do II Encontro de Atividades Científicas UNOPAR. Londrina (Pr);1999:119.

Oliveira MSM. Perfil do aleitamento materno de mães entrevistas no dia da Campanha Nacional de Multivacinação de Londrina. Londrina ( $\mathrm{Pr}$ ); Departamento de Vigilância à Saúde da Secretaria Municipal de Saúde: Divisão de Informação em Saúde, 1994.

Organización Mundial de la Salud. Pruebas científicas de los Diez Pasos hacia una Feliz Lactancia Natural. Ginebra,1998.

Organização Mundial da Saúde. Health Programmes Evaluation; 1991.

Organização Mundial da Saúde. Proteção, promoção e apoio ao aleitamento materno: o papel especial dos serviços materno-infantis. Declaração conjunta OMS/UNICEF, Genebra, 1989.

Passos MC, Lamounier JA, Da Silva CAM, De Freitas SN, Baudson MFR. Práticas de amamentação no município de Ouro Preto, MG, Brasil. Rev Saúde Pública 2000; 34(6):617-22.

Perez-Escamilla R, Segura-Millan S, Canahuati J, Allen H. Prelacteal feeds are negatively associated with breast-feeding outcomes in Honduras. J. Nutr. 1996, 126:2765-73.

Pisacane A, Graziano L, Mazzarella G, Scrpellino B, Zona G. Breastfeeding and urinary tract infection. J Pediatr 1992; 120:87-9. 
Polit DF, Hungler BP. Fundamentos de Pesquisa em Enfermagem. Porto Alegre, Artes Médicas;1995.

Powers NG, Naylor AJ, Wester RA. Hospital polices: crucial to breastfeeding success. Semin Perinatol 1994; 18(6):517-24.

Prando C, Poli LMC. Relato de experiência - implantação do projeto Iniciativa Unidade Básica de Saúde Amiga da Criança de Londrina. In: Anais do V Encontro Nacional de Aleitamento Materno. Londrina (Pr); 1997:66.

Prefeitura Municipal de Londrina. Decreto Lei n.245, de 19 de abril de 1995. Institui o Comitê de Estimulo ao Aleitamento Materno no Município de Londrina (CALMA). Folha de Londrina, Londrina, 6 de maio de 1995. Seção de classificados, p.8.

Pugin E et al. Does prenatal breastfeeding skills group education increase the effectiveness of a comprehensive promotion program? J Hum Lact. 1996; 12(1):15-19.

Rattner D Subsídios para a avaliação da qualidade do processo de assistência ao parto. Săo Paulo; 1991. [ Dissertação de Mestrado Faculdade de Saúde Pública da Universidade de São Paulo].

Réa MF. A amamentaçăo e o uso do leite humano: o que recomenda a Academia Americana de Pediatria. J Pediatr 1998; 74(3):171-3.

Réa MF Substitutos do leite materno: passado e presente. Rev Saúde Pública. 1990; 24:241-9.(a)

Réa MF. The Brazilian national breastfeeding program: a sucess story. Int. J. Gynecol. Obstet. 1990; 31(Suppl. 1):79-82.(b) 
Réa MF e Venâncio SI. Avaliação do curso de Aconselhamento em Amamentação- OMS/UNICEF. J Pediatr 1999; 75(2):112-118.

Righard L, Alade MO. Effect of delivery room routines on success of first breast-feed. Lancet 1990; 336:1105-07.

Romieu I, Werneck G, Ruiz VS, White M, Hernandez M. Breastfeeding and asthma among Brazilian children. J Asthma 2000; 37:575-83.

Saarinen UM, Kajosaari M. Breastfeeding as prophylaxis against atopic disease: a prospective follow-up study until 17 years old. Lancet 1995; 346:1065-9.

SAS Institute. SAS/STAT user's guide. Version 6, 4 th ed.; v.2. NC:SAS Institute Inc. : computer program manual; 1989.

STATSOFT, Inc. STATISTICA for Windows [computer program manual]. Tulsa, OK. 2000.

Sentone ADD, Thomson, $Z$. O caminho de uma conquista [apresentado no Hospital Universitário Regional do Norte do Paraná por ocasião da entrega da placa de Hospital Amigo da Criança; 2000 set; Londrina, Pr.]

Sheet $\mathrm{C}$ Non nutritive sucking for the promotion of physiologic stability and nutrition in preterm infants. [on line]. 1998 [11]. Avaliable from: $<U R L$ : http://mww.nichd.nih.gov/cochraneneonatal/pinelli/pinelli.htm. [2001 JUN 03].

Silva VCE; Rosseto EG; Oliveira MMB; Vannuchl MTO; Souza SNDH Estímulo ao aleitamento do prematuro em um hospital-escola público: relato de uma experiência. [Apresentado no IX Encontro Paulista de Aleitamento Materno e II Encontro Paulista de Banco de Leite Humano. 1998 agosto, 24 a 28; São Paulo- SP]. 
Singhal A, Cole TJ, Lucas A. Early nutrition in preterm infants and later blood pressure: two cohorts after randomised trials. Lancet 2001 ; 357:413-9.

Souza LMBM "Promoção, proteção e apoio." Apoio? Representações sociais em aleitamento materno. Rio de Janeiro; 1996. [Dissertação de Mestrado - Instituto Fernandes Figueira/FIOCRUZ].

Thomson Z. Estudo da prática do aleitamento materno, Londrina-PR. Londrina; 1975. [Tese de Doutorado - Universidade Estadual de Londrina].

Thomson Z, coordenador. Projeto Centro de Referência em Aleitamento Materno de Londrina. Londrina: Universidade Estadual de Londrina;1996.

Thomson Z, Brito ASJ, Cordoni Junior L. Avaliação de um programa de estímulo ao aleitamento materno. J Pediatr 1982;53(3):179-82.

Thomson Z; Vannuchi MTO; Melanda MA. Relatório sobre a situação do HURNP em relação à Iniciativa Hospital Amigo da Criança. Londrina, 1995. Material digitado e não publicado.

Tirado AR, Denzin P, Basseto MCA. A influência da nutrição não nutritiva no estado de consciência de recém-nascidos pré-termo durante a alimentação. Rev. Paul. Pediatr 1998; 16(2):81-6.

Toma TS. Iniciativa Hospital Amigo da Criança: Diagnóstico das práticas de alimentação infantil em maternidades públicas e privadas do municipio de São Paulo. São Paulo; 1998. [Dissertação de Mestrado Faculdade de Saúde Pública da USP].

Universidade Estadual de Londrina. Catálogo dos cursos de graduação 2001. Londrina.Coordenadoria de Assuntos de Ensino de Graduação: editora da UEL; 2001. 
Universidade Estadual de Londrina, Prefeitura Municipal de Londrina, Secretaria de Estado de Saúde, Conselho de Saúde da Região Sul. Projeto UNI-Londrina: uma nova iniciativa da educação dos profissionais de saúde - união com a comunidade. Londrina; 1992.

Vannuchi MTO, Imperatriz DM, Braz IC, Oliveira MMB, Souza SNDH. Banco de Leite do Hospital Universitário Regional do Norte do Paraná: unindo esforços no incentivo ao aleitamento materno. In: Anais da $1^{\text {a }}$ Mostra de Experiências do Serviço Municipal de Saúde de Londrina. Londrina(Pr); 1996:52-5.

Venâncio SI. A evolução das práticas do aleitamento materno no Brasil nas décadas de 70 e 80. São Paulo;1996 [Dissertação de Mestrado Faculdade de Saúde Pública da USP].

Verronen P. Breastfeeding: reasons for giving up and transient lactational crises. Acta Paediatr Scand 1982; 71:447-50.

Victora CG, Vaughan JP, Lombardi C, Fuchs SMC, Gigante LP, Smith PG et al. Evidence for protection by breast-feeding against infant deaths from infectious diseases in Brazil. Lancet 1987; 8:319-21.

Victora CG, Behague DP, Barros FC, Olinto MTA, Weiderpass E. Pacifiers use and short breastfeeding duration: Cause, consequence, or coincidences? Pediatrics 1997; 99(3):445-53.

Vinha VHP, Pelá NTR, Scochi CGS, Shimo AKK, Gameiro C. Manutenção da lactação da mãe do prematuro. Femina 1988;16(11):994-7. 
Westin JB. Ingestion of carcinogenic $\mathrm{N}$-nitrosamines by infants and children. Arch. Environ. Health 1990; 45(6):359-63.

Westphal MF, Taddei JAC, Venâncio SI, Bogus CM. Breast-feeding training for health professionals and resultant institutional changes. Bull. World Health Organ 1995; 73:461-8.

Windstrom AM. Short-term effects of early sucking and touch on maternal behavior. Early Hum Dev 1990; 21:153.

Wiles $L$. The effect of prenatal education on breastfeeding success and maternal perception of the infant. Obstet. Gynecol. Neonatal Nurs 1984; julaug: $253-57$.

Williams C, Birch EE, Emment PM, Northstone K. Stereoacuity at age $3.5 \mathrm{y}$ in children born full-term is associated with prenatal and postnatal dietary factors: a report from a population-based cohort study. Am J Clin Nutr 2001; 73:31622.

Winikoff B, Laukaran VH, Myers D, Stone R. Dynamics of infant feeding: mothers, professionals and the institutional context in a large urban hospital. Pediatrics 1986; 7(3): 357-365.

World Health Organization. Global strategy for infant and young child feeding. Document A 54/7, Geneva, 9 April 2001.

Wright A, Rice S, Wells $S$. Changing hospital practices to increase the duration of breastfeeding. Pediatrics. 1996; 97(5):669-75. 
Wright AL, Holberg CJ, Taussig LM, Martinez FD. Factors influencing the relation of infant feeding to asthma and recurrent wheezy in childhood. Thorax 2001; 56:192-7.

Xavier CC, Jorge SM, Gonçalves AL. Prevalência do aleitamento materno em recém-nascidos de baixo peso. Rev Saúde Pública 1991; 25(5):381-7.

Zheng T, Duan L, Liu Y, Zhang B, Wang Y, Chen Y, Zhang Y, Owens PH Lactation reduces breast cancer risk in Shandong Province, China. Am J Epidemiol 2000; 152:1129-35.

Ziegel EE e Cranley MS. Enfermagem obstétrica. 8 ed. Rio de Janeiro, Interamericana, 1985. Recém-nascido de alto risco: características e assistência de enfermagem;p.570-605. 


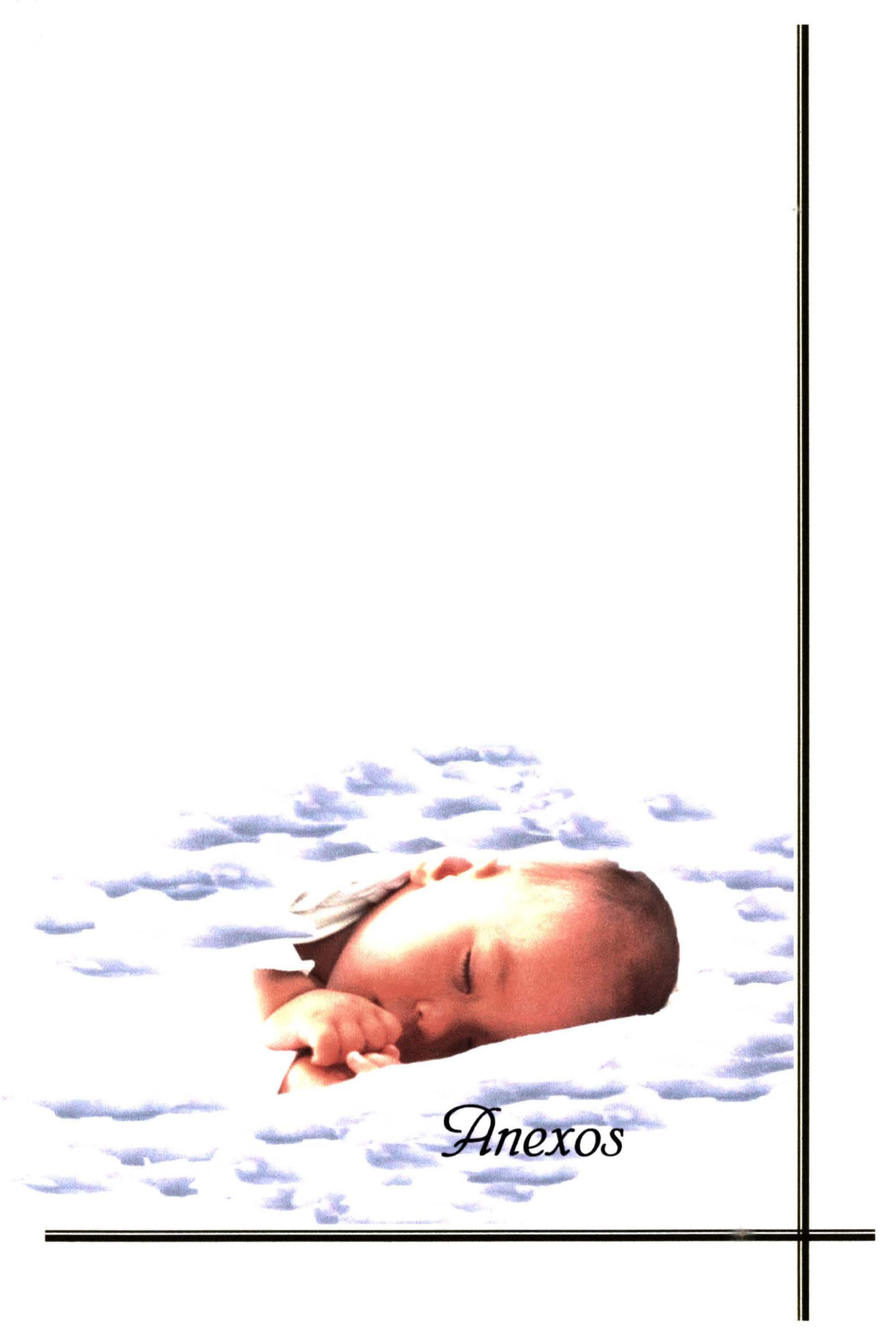




\title{
ANEXo 1
}

\author{
UNIVERSIDADE DE SÃO PAULO \\ FACULDADE DE SAÚDE PÚBLICA \\ COMITÊ DE ÉTICA EM PESQUISA DA FSP/USP - COEP \\ Av. Dr. Amaldo, 715 - CEP 01246-904 - São Paulo - Brasil \\ Telefones: (55-11) 30667742 - fax (55-11) 30647314
}

Of. COEP/197/99

08 de outubro de 1999

Pelo presente, informo que o Comitê de Ética em Pesquisa da Faculdade de Saúde Pública da Universidade de São Paulo-COEP, analisou e aprovou, em sua $7^{\mathrm{a}} / 99$ Sessão Ordinária, de 07.10.99, de acordo com os requisitos da Resolução CNS/196/96, o protocolo de Pesquisa n. 173 intitulado: "AVALIAÇÃO DA EFETIVIDADE DE AÇÕES PRÓ-AMAMENTAÇÃO NA UNIDADE DE NEONATOLOGIA DO HOSPITAL UNIVERSITÁRIO REGIONAL DO NORTE DO PARANÁ LONDRINA", apresentado pela pesquisadora Marli Terezinha Oliveira Vannuchi

Atenciosamente,

Prof. Dr. Paulo A thrifde Carvalho Fortes

Vice-Coordenador do Comit de tica em Pesquisa da FSP-COEP 


\title{
ANEXO 2
}

\section{HOSPITAL UNIVERSITÁRIO REGIONAL DO NORTE DO PARANÁ COMITÉ DE BIOÉTICA}

\author{
À Senhora \\ PROFa MARLI TEREZINHA OLIVEIRA VANNUCHI \\ Centro de Ciências da Saúde \\ Nesta
}

Prezada Senhora,

A avaliação do projeto de Pesquisa "Avaliação da efetividade de ações pró-amamentação na unidade de Neonatologia do HURNP" não apresenta qualquer impedimento ético para ser realizado já que trata-se de uma avaliação retrospectiva de dados de recém-nascidos internados na Unidade de Neonatologia do HURNP no período de 1996 e 1998. Sugerimos apenas que V.Sa. oficie o responsável da mencionada unidade hospitalar sobre a metodologia de seu trabalho e faça constar a autorização do mesmo nos documentos anexos ao texto definitvo de sua tese.

Atenciosamente

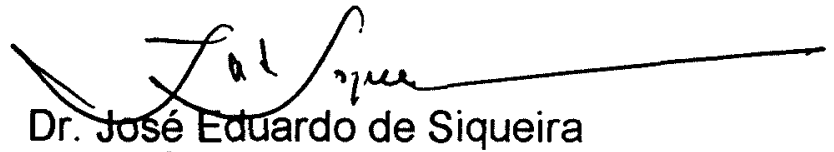

Comitê de Ética em Pesquisa da UEL

Presidente 


\title{
ANEXO 3
}

Londrina, 08 de Novembro de 1999

\author{
Ao Senhor \\ Prof. Dr. Sylvio Villari Filho \\ Diretor Clinico do HURNP
}

Prezado Senhor

Como aluna do curso de Doutorado em Saúde Pública da Faculdade de Saúde Pública da USP, venho por meio deste solicitar autorização para iniciar a coleta de dados para a nossa tese que versará sobre:"Avaliação da Efetividade de Ações Próamamentação na Unidade de Neonatologia do HURNP". A coleta de dados consiste na análise de prontuários de todas as crianças que nasceram e nacessitaram de internação na unidade de neonatologia deste hospital, durante os anos de 1994 e 1998. Serão analisados 305 prontuários de 1994 e 390 de 1998, tendo como foco principal o regime alimentar recebido por estas crianças durante o periodo de hospitalização.Em fumção do elevado número de prontuários a serem analisados, contaremos com o auxílio das seguintes acadêmicas do curso de Enfermagem/UEL:

.Camila Helen de Oliveira

Eliana Brugin

Karine de Oliveira Fernandes Pinheiro

.Luiza Rita Pachemshy

.Valéria Cristina Gâmbaro

Informamos que o projeto desta tese, foi aprovado pelo Comitê de Bioética do HURNP em 23/8/99 com o parecer n.040/99.

Antecipadamente, agradecemos a colaboração.

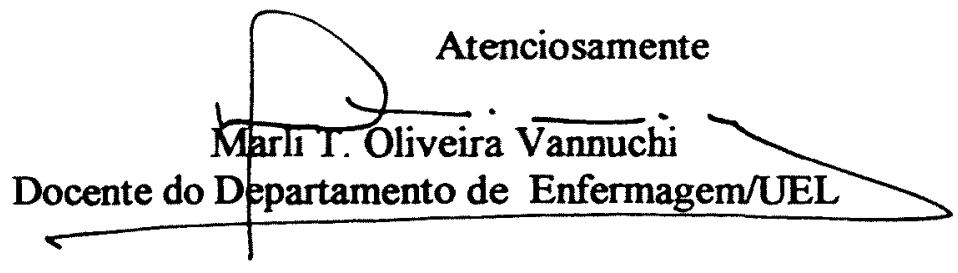

Com cópia para: Dra Ana Berenice R.de Carvalho

Chefia Médica da UTI Neonatal/HURNP

e

Enfa. Andreza D. D. Sentone

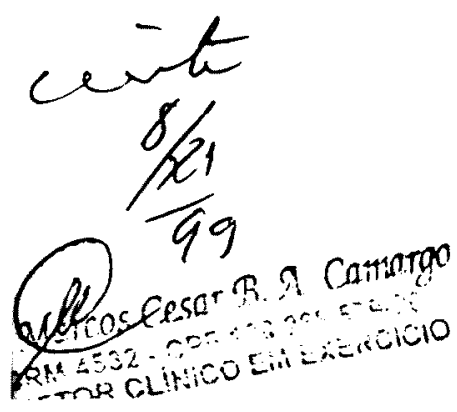

Chefe da Divisão Materno-Infantil/Diretoria de Enf./HURNP 


\section{ANEXO 4}

Ao Senhor

Londrina, (08 de Novembro de1999

Prof. Dr. Sylvio Villari Filho

Diretor Clínico do HURNP

Prezado Senhor

Como aluna do curso de Doutorado em Saúde Pública da Faculdade de Saúde Pública da USP, venho por meio deste solicitar autorização para iniciar a coleta de dados para a nossa tese que versará sobre:"Avaliação da Efetividade de Ações Próamamentação na Unidade de Neonatologia do HURNP". A coleta de dados consiste na análise de prontuários de todas as crianças que nasceram e nacessitaram de internação na unidade de neonatologia deste hospital, durante os anos de 1994 e 1998. Serão analisados 305 prontuários de 1994 e 390 de 1998, tendo como foco principal o regime alimentar recebido por estas crianças durante o período de hospitalização.Em fumção do elevado número de prontuários a serem analisados, contaremos com o auxílio das seguintes acadêmicas do curso de Enfermagem/UEL:

Camila Helen de Oliveira

.Eliana Brugin

Karine de Oliveira Fernandes Pinheiro

Luiza Rita Pachemshy

Valéria Cristina Gâmbaro

Informamos que o projeto desta tese, foi aprovado pelo Comitê de Bioética do HURNP em 23/8/99 com o parecer n.040/99.

Antecipadamente, agradecemos a colaboração.
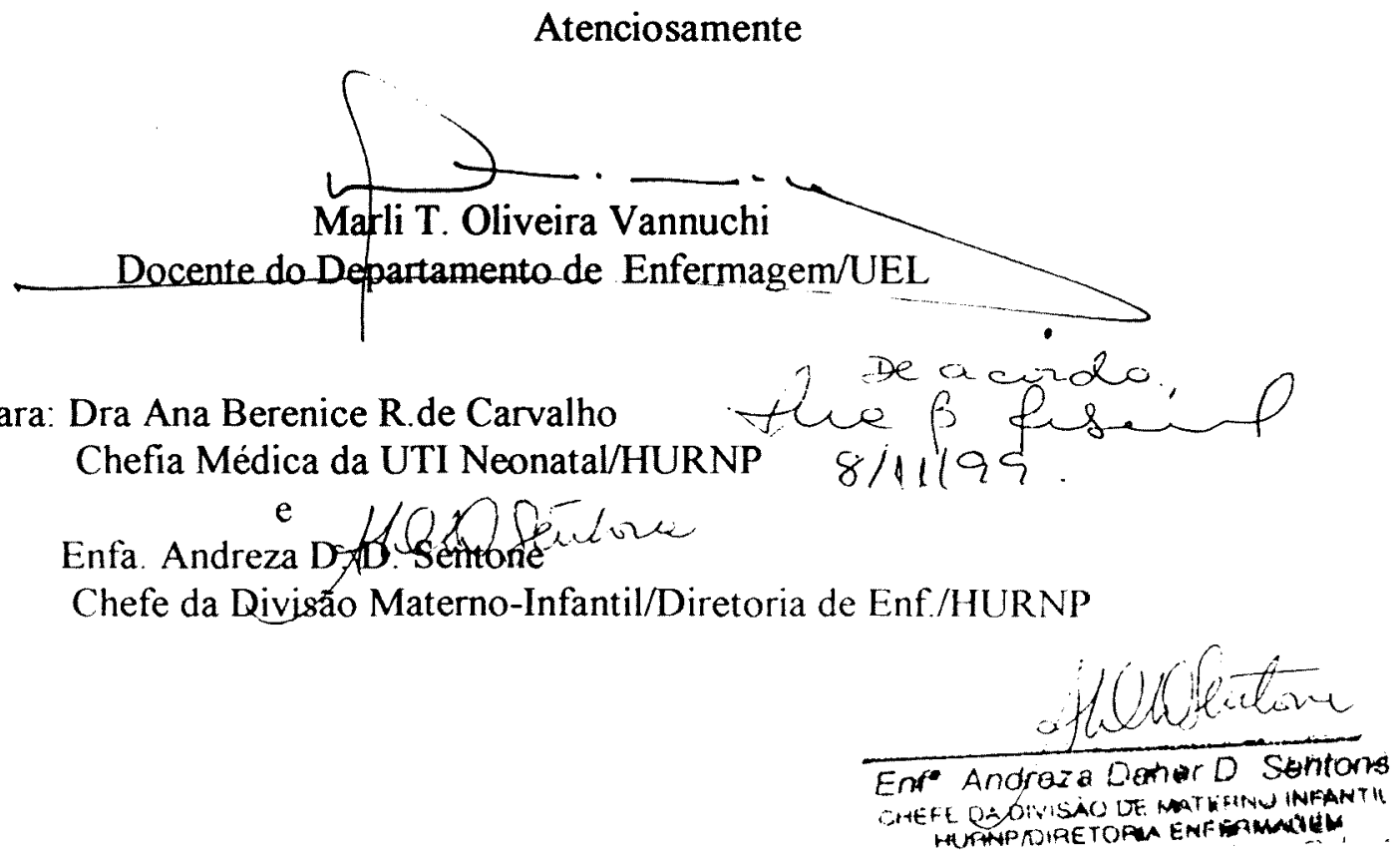


\section{ANEXO 5}

DADOS DO RN: MÊS: ANO:

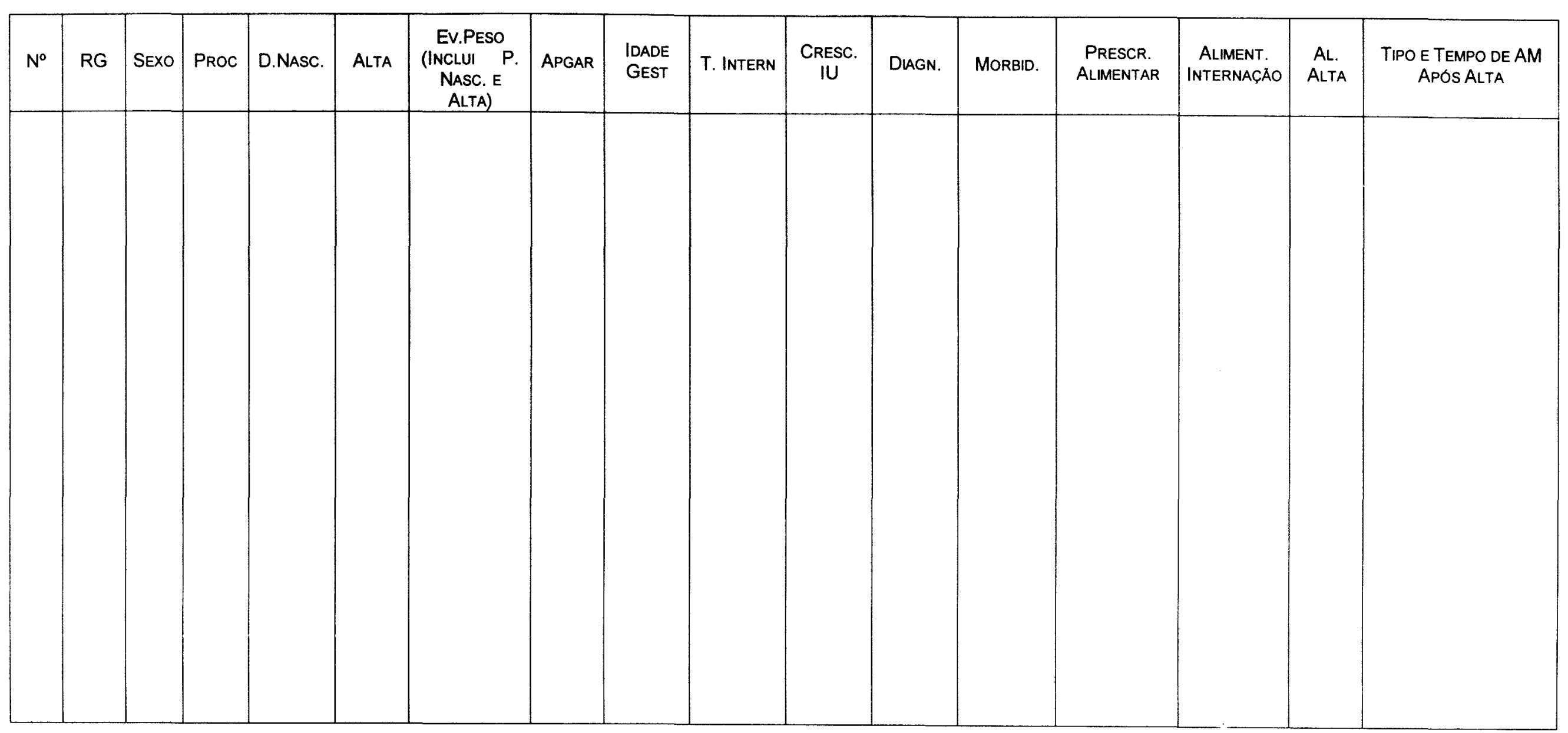


Anexo 5

DADOS DA MÃE:

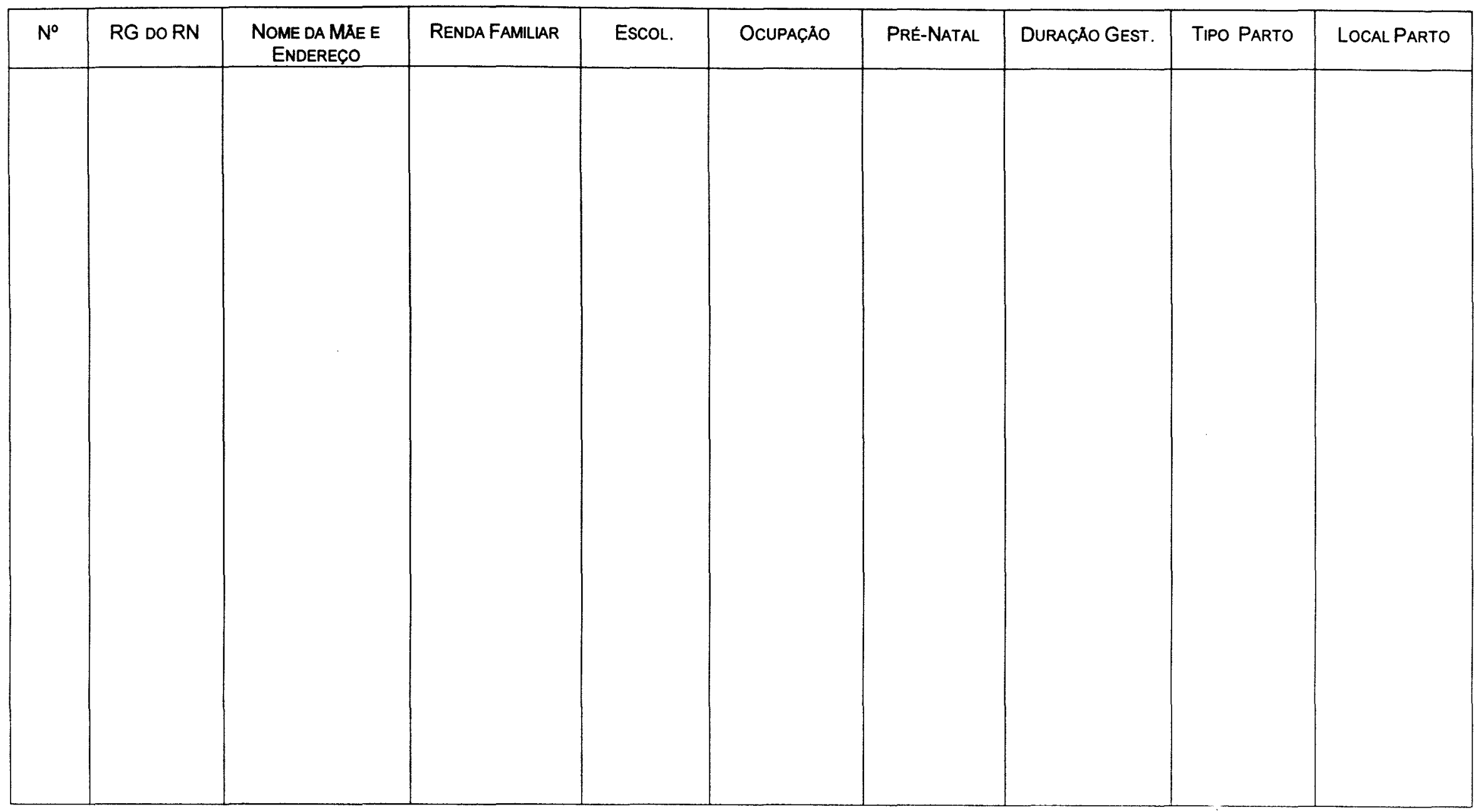




\section{ANEXO 6 \\ ROTEIRO DE ENTREVISTA}

1. Qual é a sua profissão?

2. Há quanto tempo trabalha na UTI/UCI Neonatal do HURNP?

3. Você que vivenciou desde 0 início este processo de mudanças de rotinas referentes ao AM na UTI/UCI Neonatal do HURNP, na sua opinião, qual é a mudança que você considera a mais importante?

O HURnP, acaba de ser designado "Hospital Amigo da Criança", portanto toda sua equipe deve praticar os 10 passos para o sucesso da amamentação preconizado pela Iniciativa Hospital Amigo da Criança (IHAC), que resume as práticas para apoiar o AM nos hospitais.

Passo 1 - Ter uma Norma Escrita Sobre Aleitamento Materno, que Deve Ser Rotineiramente Transmitida a Toda Equipe.

4. Existia alguma norma sobre $A M$ na Unidade de Neonatologia quando inaugurou a UTI Neotanal?
( ) Sim
( ) Não. Quando teve conhecimento?

5. Você acha que esta norma escrita contribuiu para mudar as rotinas do AM na UTI/UCI Neonatal? 
6. Qual o grau de importância você atribui a ela?

( ) Muito Importante

( ) Importante

( ) Pouco Importante

( ) Nenhuma

( ) Não Sei

Por que?

7. Frente ao conteúdo existente na norma, na sua opinião, qual foi o conteúdo mais fácil de ser de ser implantado e qual foi o mais dificil?

\section{Passo 2 - Treinar toda a Equipe de Cuidados de Saúde, Capacitando-a PARA IMPLEMENTAR ESTA NORMA.}

8. Você recebeu algum tipo de treinamento após iniciar o processo da IHAC?

( ) Sim. Qual foi a duração?

( ) Não

9. Voce recebeu orientação sobre manejo clínico ou seja, aulas práticas sobre $A M$ ? Se recebeu, quais foram?

10. Você acha que este treinamento da equipe influenciou para mudar as rotinas do AM na UTI/UCI Neonatal?

11.Qual é o grau de importância que você atribui a este treinamento para mudanças das rotinas do AM nestas unidades?

( ) Muito Importante

( ) Importante

( ) Pouco Importante

( ) Nenhuma

( ) Não Sei

Por que? 
12. Este treinamento acrescentou algum conteúdo novo além da prática que você já possuia no início da implantação da UTI Neonatal?

13. Na sua opinião, a implantação deste passo foi alcançada na UTI/UCl Neonatal?
( ) $\operatorname{Sim}$
( ) Não. Por que?
( ) Não Sei

Passo 3 - Informar Todas as Gestantes Sobre as Vantagens e o Manejo da Amamentação.

14. Este passo é realizado durante as consultas da mãe no pré-natal. Na sua opinião, qual é o grau de importância que você atribui a este passo, nas mudanças das rotinas do AM na UTI/UCI Neonatal?

( ) Muito Importante

( ) Importante

( ) Pouco Importante

( ) Nenhuma

( ) Não Sei

Por que?

\section{Passo 4 - Ajudar as mães a Iniciar a Amamentação na Primeira Meia Hora Após o Parto.}

15. Este passo deve ser realizado ainda na sala de parto. Você acha que a implantação deste passo contribuiu para mudar as rotinas do AM na UTI/UCI Neonatal? 
16. Qual é o grau de importância que você atribui a este passo, nas mudanças das rotinas do AM na UTI/UCI Neonatal?

( ) Muito Importante

( ) Importante

( ) Pouco Importante

( ) Nenhuma

( ) Não Sei

Por que?

Passo 5 - Mostrar às Mães Como Amamentar e Como Manter a lactação, Mesmo Que Vierem a Ser Separadas de Seus Filhos.

- No inicio da implantação da Uti neonatal, enquanto o Bebe PERMANECIA INTERNADO:

17. Como a mãe era orientada para amamentar seu bebê?

18. Como era mantido o processo de lactação da mãe?

- Após a implantação da iHAC:

19. Houve alguma mudança na orientação dada a mãe sobre como amamentar seu bebê?

20. Houve alguma mudança na orientação dada a mãe sobre o processo de lactação da mãe?

21. O passo 5 contribuiu para mudanças de rotina do $A M$ na Unidade de Neonatologia? 
22. Qual é o grau de importância que você atribui a ele?
( ) Muito Importante
( ) Importante
( ) Pouco Importante
( ) Nenhuma
( ) Não Sei
Por que?

23. Na sua opinião, a implantação deste passo foi alcançada?
( ) Sim
( ) Não. Por que?
( ) Não Sei

\section{Passo 6 - Não Dar ao Recém-Nascido Nenhum outro Alimento ou Líquido além do leite Materno, a Não Ser que haja Indicaçāo Médica.}

24. Na inauguração da uit neonatal, qual era o leite mais indicado pelos médicos para os RN internados?

25. Na prática, qual era o leite comumente oferecido a estes RN pela equipe de enfermagem? Por que?

26. Após a IHAC, houve alguma mudança quanto ao tipo de leite prescrito pelos médicos aos RN internados na UTI/UCl?

27.Qual é o segundo tipo de leite prescrito pelos médicos a estas crianças?

28. Na prática, qual é o leite comumente oferecido ao RN pela equipe de enfermagem? 
29. Na sua opinião qual é a contribuição do BLH na mudança das rotinas do AM na UTI/UCI Neonatal?

30. Qual é o grau de importância que você atribui a ele?
( ) Muito Importante
( ) Importante
( ) Pouco Importante
( ) Nenhuma
( ) Não Sei
Por que?

31. Voce acha que o passo 6 contribuiu para mudanças de rotinas do AM na Unidade de Neonatologia?

32. Qual é o grau de importância que você atribui a ele?
( ) Muito Importante
( ) Importante
( ) Pouco Importante
( ) Nenhuma
( ) Não Sei

33. Você acha que a implantação deste passo foi alcançada?
( ) Sim
( ) Não. Por que?
( ) Não Sei 
Passo 7 - Praticar o alojamento Conjunto - Permitir que Mãe e Bebé Permaneçam Juntos - 24 Horas por Dia.

34. Na sua opinião, as rotinas de 1994, permitiam livre acesso da mãe durante a internação do RN na UTI/UCl?

35. Atualmente, quanto tempo se permite que a mãe permaneça na UTI/UCl Neonatal junto ao seu bebê? Por que?

36. Você acha que o passo 7 contribuiiu para mudanças de rotinas referentes ao AM na Unidade de Neonatologia do HURNP?

37. Que grau de importância você atribui a ele?

( ) Muito Importante

( ) Importante

( ) Pouco Importante

( ) Nenhuma

( ) Não Sei

Por que?

38. A implantação deste passo foi alcançada?

( ) $\operatorname{Sim}$

( ) Não. Por que?

( ) Năo Sei

Passo 8 - Encorajar a Amamentação Sob livre Demanda.

39. Na sua opinião, no início da implantação da UTI Neonatal, o Passo 8 era adotado para os RN que necessitavam permanecer internados? Por que? 
40. E após a IHAC, houve alguma mudança neste sentido? Por que?

41. Você acha que o Passo 8 contribuiu para mudar as rotinas do AM na UTI/UCI Neonatal?

42. Qual é o grau de importância que você atribui a ele?

( ) Muito Importante

( ) Importante

( ) Pouco Importante

( ) Nenhuma

( ) Não Sei

Por que?

43. A Implantação deste passo foi alcançada na UTI/UCI Neonatal?
( ) $\operatorname{Sim}$
( ) Não. Por que?
( ) Năo Sei

\section{Passo 9 - não dar Bicos artificlals ou Chupetas a Crianças Amamentadas ao Seio}

44. Na sua opinião, no início da UTI Neonatal, as rotinas permitiam a presença de mamadeiras e chupetas para os bebês internados?

45. Após a IHAC, você acha que houve mudanças neste sentido?

46. Existe alguma situação em que se indica o uso de bicos artificiais ou chupetas?

47. Voce acha que este passo contribuiu para mudanças de rotinas relativas ao AM na Unidade de Neonatologia? 
48. Qual é o grau de importância que você atribui a ele?
( ) Muito Importante
( ) Importante
( ) Pouco Importante
( ) Nenhuma
( ) Não Sei.

Por que?

49. A implantação deste passo foi alcançada na UTI/UCI Neonatal ?
( ) $\operatorname{Sim}$
( ) Não. Por que?
( ) Não Sei
Passo 10 - Encorajar a formação de Grupos de Apolo ao am, Para Onde as Mães Deverão Ser Encaminhadas por Ocasião da Alta Hospitalar ou Ambulatorial.

50. Na alta hospitalar é dada alguma orientação quanto a algum grupo de referência, caso haja qualquer problema com a amamentação? Qual(is)?

51. Você acha que este passo foi importante para mudar as rotinas do AM na UTI/UCI Neonatal?

52. Qual é o grau de importância que você atribui a ele para mudar as rotinas do AM na UTI/UCl?
( ) Muito Importante
( ) Importante
( ) Pouco Importante
( ) Nenhuma
( ) Não Sei

Por que?

53. O passo 10 foi alcançado?
( ) $\mathrm{Sim}$
( ) Näo. Por que?
( ) Năo Sei 


\section{ANEXO 7}

\section{TERMO DE CONSENTIMENTO LIVRE E ESCLARECIDO}

(A ser lido e assinado pelos profissionais de saúde que serão entrevistados, conforme exigido pela Resolução no 196/96 do Conselho Nacional de Saúde)

O presente questionário tem a finalidade de buscar dados para nossa Tese de Doutorado que versa sobre: Avaliação da EfEtividade de AÇóes Pró-Amamentaçāo na Unidade de Neonatologia do HURNP-LondRina. Esta pesquisa propõe estudar até que ponto as ações, no sentido de reestruturar as rotinas relativas ao aleitamento materno, contribuiram para a mudança do regime alimentar de RN internados na Unidade de Neonatologia do HURNP (UTI/UCl) e a sua contribuiçăo na evolução de saúde dos RN.

Pelos dados coletados até o momento, verificou-se que em 1994 os RN internados receberam predominantemente fórmulas e, em 1998 receberam predominantemente leite humano (leite da própria mãe e/ou leite do banco de leite materno).

Para sabermos quais foram as ações mais efetivas neste processo de mudanças, precisamos da sua colaboração respondendo à nossas perguntas e permitindo que a nossa conversa seja gravada. $O$ gravador serve para que eu não perca nada do que você vai falar. Depois da nossa entrevista, - que foi conversado vai ser escrito e a fita do gravador será apagada. O seu nome, não irá aparecer em nenhum papel da pesquisa, ou seja, o que você me falar não vai ser ligado a sua pessoa de forma alguma.

É importante que você saiba que tem toda a liberdade em participar ou não da pesquisa, podendo desistir a qualquer momento sem 
nenhum prejuizo.

Qualquer dúvida que você tiver ou qualquer informação, poderá entrar em contato comigo pelos endereços

\section{Telefone: $327-2559$}

e-mail: vannuchi@onda.com.br

Agradeço a sua colaboração.

Atenciosamente

Marli T. Olioeira Vannucbi

Compreendo o que Fol EXPlicado e Concordo em Participar.

Data: '

Nome:

Assinatura: 